\title{
Increasing the effectiveness of participatory scenario development through codesign
}

\author{
$\underline{\text { Marissa F. McBride }}^{1}, \underline{\text { Kathleen F. Lambert }}^{2}$, Emily S. Huff $^{3}, \underline{\text { Kathleen A. Theoharides }}^{4}, \underline{\text { Patrick Field }}^{5}$ and Jonathan R. Thompson $^{1}$
}

\begin{abstract}
Developing scenarios to explore possible environmental futures is a widely used tool in social-ecological research. Scenario planners working in environmental systems increasingly enlist stakeholders to help develop scenarios, but effectively integrating stakeholder participation with scenario analyses and modeling remains a challenge. Using the New England Landscape Futures project as a case study, we explore how a method for codesigning a scenario elicitation process can be used to help balance the needs of both stakeholders and scientists. To illustrate the design process, we document eight influential decisions made with stakeholder input, describe the competing demands that we negotiated, and outline the rationale for the selected approach. We find that three priorities drove most of our decisions: maximizing stakeholder involvement in the scenario development process, efficient use of stakeholder time, and research needs. The outcome was a robust, intense, and highly structured one-day scenario development protocol that engaged stakeholders in the full scenario development process from initial orientation and identification of driving forces through to fleshedout scenarios narratives and quantitative inputs able to inform land-use simulations. Its deployment in six state-specific workshops was successful in eliciting divergent scenarios that stakeholders perceived as being plausible and relevant. Stakeholder responses to the process were positive, though also reflected the compromises made during the codesign process. Research needs were largely met, though initial expectations likely exceeded what could reasonably be elicited from a stakeholder group in one day. Our experiences highlight the importance of process design and how selection of scenario development techniques should follow from the project objectives, problem context, and stakeholder preferences for engagement activities. The use of a codesign framework that recognizes the challenges involved and engages stakeholders in the design process can act as a shared learning experience and contribute to greater effectiveness and impact for participatory social-ecological scenario processes.
\end{abstract}

Key Words: boundary spanning; land-use change; participatory research; scenarios; stakeholder engagement; transdisciplinary

\section{INTRODUCTION}

Scenario planning is a method for structured exploration of multiple hypothetical futures that provides a powerful way to explore and understand social-ecological systems while explicitly acknowledging their inherent uncertainty (Peterson et al. 2003). Scenarios are consistent and coherent storylines that reflect different hypotheses about how the future might unfold. By exploring and testing assumptions about possible futures, scenarios can broaden conventional thinking, enhance understanding, and generate new insights relevant to taking meaningful action in complex, dynamic systems (Henrichs et al. 2010, Wilkinson et al. 2013). As such, scenario planning has become popular in social-ecological research and environmental planning as a means for analyzing complex problems and facilitating transformative change (e.g., Rothman 2008, Thompson et al. 2012, Chaudhury et al. 2013, Carpenter et al. 2015, Daw et al. 2015, Oteros-Rozas et al. 2015).

Scenario planners working in environmental systems are increasingly enlisting stakeholders to help develop scenarios (Seppelt et al. 2011, Oteros-Rozas et al. 2015). Following Reed et al. (2013:346) stakeholders can be defined as "those who are affected by or can affect a decision or action." Engaging stakeholders in scenario development has a wide range of potential benefits, including: improving the quality and relevancy of the scenarios by incorporating diverse perspectives and local knowledge, empowering stakeholders, fostering shared sense making, and helping to enhance the perceived legitimacy and ownership of the results (Berkhout et al. 2002, Cash et al. 2003, Pahl-Wostl 2008). The popularity of participatory approaches may be credited to a growing awareness that the closer scenario development processes are linked to the actual actors involved, the more likely they are to generate relevant insights and to result in successful uptake and action (e.g., Johnson et al. 2012, Vervoort et al. 2014, Bennett 2017).

The result has been a proliferation of methods for, and applications of, participatory environmental scenarios (Volkery et al. 2008, Seppelt et al. 2011, Oteros-Rozas et al. 2015). Although all participatory practices engage stakeholders, they vary in terms of the timing, amount, and type of engagement (Reed et al. 2013, de Vente et al. 2016). For example, stakeholder involvement can range from primarily one-way consultation processes, which dominate the environmental scenario literature (Oteros-Rozas et al. 2015), to more collaborative processes in which researchers and stakeholders codesign the scenario development process to ensure the result meets their needs (Wollenberg et al. 2000, PahlWostl 2008, Volkery and Ribeiro 2009, Henrichs et al. 2010).

The design of a participatory scenario development process involves balancing competing legitimacy, credibility, and saliency demands (Cash et al. 2003, Henrichs et al. 2010, Kunseler et al. 2015). Trade-offs exist, for example, between the amount of involvement required and the ability of stakeholders to participate, and between process complexity and transparency (Volkery et al. 2008, Rounsevell and Metzger 2010, Wright et al.

\footnotetext{
${ }^{1}$ Harvard Forest, Harvard University, Petersham, Massachusetts, ${ }^{2}$ Harvard Forest, Harvard University and Science Policy Exchange, Petersham, Massachusetts, ${ }^{3}$ Michigan State University, Department of Forestry, East Lansing, Michigan, ${ }^{4}$ Climate and Global Warming Solutions, Executive Office of Energy and Environmental Affairs, Boston, Massachusetts, ${ }^{5}$ Consensus Building Institute, Cambridge, Massachusetts

Erratum: There were errors in the originally published Figure 4 and Appendix 3. The errors were corrected on 16 May 2018.
} 
2013). The imperative for explicit scenario design and the need for balancing competing demands, however, has not yet translated into greater attention to the design of the scenario development process itself. Most studies appear to design or select their scenario approach in an ad-hoc manner (Alcamo 2008a, OterosRozas et al. 2015), with little front-end stakeholder engagement when choosing scenario development processes (Alcamo 2008a, Kok et al. 2011). Scenario applications in the literature, for example, rarely describe the design of the scenario development process or provide rationales for the methods selected (though exceptions exist, e.g., Mitchell et al. 2016). Applications of landuse scenario processes are still in the early stages of learning how to effectively combine stakeholder and scientific (model-based) inputs (Booth et al. 2016, Mallampalli et al. 2016) and have yet to move beyond this exploratory phase toward demands for increased rigor or guidelines in the methods selected for scenario development (Rounsevell et al. 2012, Van Berkel and Verburg 2012, Capitani et al. 2016).

This lack of attention to the scenario development design process is an important gap that risks undermining the level of support offered for the scenario process by the stakeholders and by the people and institutions who authorize them to act (i.e., authorizing environment; Table 1), and therefore the legitimacy and ultimate uptake of results (Kok et al. 2011, Kirchhoff et al. 2013, Mauser et al. 2013). It also risks limiting the utility of the resulting scenarios to researchers (Alcamo 2008b) and the ability of scenario practitioners to learn from and build on past practices and modify participatory scenario processes to better achieve their stated objectives (Oteros-Rozas et al. 2015).

We use the New England Landscape Futures Project as a case study to (1) illustrate a process for collaboratively designing a land-use scenario development process in conjunction with both stakeholders and simulation modelers, (2) evaluate the strengths and weaknesses of the resulting participatory scenario development process, (3) explore how a codesigned process can promote the cooperative ownership of the scenario process and enhance the credibility, salience, and legitimacy of project outcomes. We highlight how the scenario development techniques should follow from project objectives (including research objectives), the problem context, and stakeholder preferences for engagement activities. We also make the case for codesigning the scenario development process using methods that are transparent and replicable. Finally, we reflect on our experience with codesign and potential avenues for improving the application of scenario process codesign in the future. Note that although definitions may vary, we use "codesign" to refer to a collaborative approach that actively involves stakeholders in the design process to provide a joint framing of objectives and challenges, and to help ensure the process and results meet their needs and are usable (Mauser et al. 2013).

\section{CASE STUDY: ADVANCING SUSTAINABLE LAND-USE FUTURES IN NEW ENGLAND}

\section{Problem context}

New England is an 18-million hectare region in the northeastern United States that includes 6 states throughout which total forest cover exceeds $80 \%$, but ranges from $50 \%$ (Rhode Island) to $90 \%$ (Maine). Eighty percent of the region's forests are privately owned, including the nation's largest contiguous block of private commercial forestland ( $>$ four million ha) and hundreds of thousands of family forest owners with small to mid-sized parcels totaling $>$ seven million hectares (Butler et al. 2016). After 200 years of forest regrowth following abandonment of colonial-era agriculture expansion, all of the New England states are now losing forest cover (Olofsson et al. 2016). The majority of forest loss is associated with low-density residential development. No centralized authority exists in New England to regulate land use. Instead, it is loosely coordinated through a patchwork of regional planning entities, state policies and permits, and local planning boards. In addition, land trusts and other types of conservation organizations operate to protect valued resources through easements and fee acquisition (approximately, 23\% of the region is protected from development) and promote smart growth and other land-use planning measures. This dispersed problem context in which land-use decisions are in the hands of hundreds of thousands of individual land owners defies a predictive approach to understanding and analyzing future landscape conditions and lends itself to a participatory scenarios process that engages diverse stakeholders from across the region in elaborating a range of possible futures.

\section{The New England Landscape Futures Project}

The New England Landscape Futures Project (NE-LFP) is an initiative led by the Harvard Forest as a focus of its Long-Term Ecological Research program (LTER) and an associated Research Coordination Network (landscape scenarios, ecosystem services, and benefits to society; $\mathrm{S}^{3} \mathrm{RCN}$ ). Both the Harvard Forest LTER and the $\mathrm{S}^{3} \mathrm{RCN}$ have the dual objectives of advancing research and informing sustainable land-use policy and planning in New England by facilitating knowledge coproduction and collaborative action with practitioners from the public, private, and nonprofit sectors (Foster 2013, Foster et al. 2014). The primary organizing questions of the NE-LFP are (1) how might the New England landscape change over the next 50 years?; (2) what are the possible consequences for people and nature?; and (3) what actions could help sustain important resources in the face of change? The NE-LFP aims to answer these questions by engaging scientists, business owners, government officials, landowners, and nonprofit representatives in the development of a set of alternative landscape futures (scenarios) for New England, as a tool through which to coproduce legitimate and salient knowledge about the consequences of different land-use trajectories for ecosystem services that can inform land-use planning, conservation, and management decisions (e.g., Thompson et al. 2016). Specially, the project aims to:

1. forge a collaborative regional network of researchers and practitioners to better understand land-use challenges facing New England in a time of global change;

2. synthesize and catalyze research about the consequences of alternative land-use futures by codeveloping and sharing scenario narratives and simulations;

3. apply insights to near-term policy, planning, and land management and conservation decisions to help policy makers and practitioners prepare for a suite of novel future land-use challenges; and

4. develop scenario narratives, simulation models, interactive communication products, and re-engagement processes to support that application. 
Table 1. Characteristics of the New England Landscape Futures Project.

\begin{tabular}{|c|c|c|c|}
\hline $\begin{array}{l}\text { Project } \\
\text { characteristics }\end{array}$ & $\begin{array}{l}\text { Description or } \\
\text { categories }\end{array}$ & Relevance/examples & New England Landscape Futures Project (NE-LFP) \\
\hline Subject of focus & $\begin{array}{l}\text { Issue-based, area-based, } \\
\text { or institution-based }\end{array}$ & $\begin{array}{l}\text { Issue-based scenarios take societal issues as the subject of } \\
\text { study (e.g., the future of oil), area-based scenarios explore a } \\
\text { particular geographical area such as a country, region, or city } \\
\text { (e.g., the VISION futures project for Europe), and institution- } \\
\text { based scenarios address the concerns of an organization or } \\
\text { sector (e.g., the company Shell). Overlaps between two or } \\
\text { more subject types are also possible. }\end{array}$ & $\begin{array}{l}\text { As a study concerned with the future of land use in } \\
\text { New England, the focus was primarily area-based, with } \\
\text { a secondary issue-based consideration relating to land- } \\
\text { use change and provisioning of ecosystem services. }\end{array}$ \\
\hline
\end{tabular}

Authorizing environment

Time and resources available

Outcome goals Process or product

Timeline of interest

The authorizing available, research skills to long-term (e.g., environment for an entity refers to the leve of support offered for the scenario process and products by stakeholders and the institutions and people who authorize them to take action

The financial resources resources, time invested in the project, available personnel and their more subject types are also possible. An understanding of the authorizing environment from the start is important, given that a strong authorizing environment, or the lack thereof, is one of the most influential factors in the successful uptake of scenario planning products (e.g., van der Heijden 1996, Schoemaker 1998). In most business scenario exercises in which top-level management is involved, for example, the authorizing environment is strong. However, for many scenario planning exercises that focus on societal and environmental issues outside of any one institution, this is not the case.

The process and design of a scenario analysis is necessarily influenced by the nature of the resources available (van der Heijden 1996, Schoemaker 1998). For example, whether or not there are the extensive resources available in the order of large-scale, high-profile assessments like the MEA, or the Mont Fleur Scenarios, in which there were resources available for extended numbers of workshops and the involvement of considerable numbers of stakeholders, skilled researchers, and scenario-planning experts.

Whether the intent is to make use of scenario planning as a process (i.e., a learning experience for actors involved in the scenario development) or as a product (i.e., the actual set of scenarios themselves), or as both a process and a product, may influence the development design.

Short (e.g., 10-20 years) $40-50+$ years)
Scenario time horizons can range from short to midterm (e.g. 10-20 years) to more long-term exercises (e.g., 40-50 years) Shorter-term scenarios will usually align more closely with existing trends and may be perceived as having greater relevancy to existing decision-making needs, whereas longer time horizons allow for greater structural changes to occur and may be important when dealing with slow-changing phenomena, like those addressed in many environmental and societal issues.
This case study had a diverse and diffuse authorizing environment because there are many agencies, NGOs, and businesses that make decisions relevant to the scenarios, with the NE-FLP operating outside of, and without any direct influence on, the region. In addition, there was no public agency or private entity that commissioned the scenario project.

The support of the $\mathrm{S}^{3} \mathrm{RCN}$, Harvard Forest LTER V, and Highstead Foundation permitted a scenario exercise of moderate scale, including funding for two full-time postdocs, two PIs (at 20\% FTE), and resources dedicated to supporting nonscientific involvement in the form of a $50 \%$-time project coordinator and funding and professional facilitation for six stakeholder workshops.

The aim was for the scenario exercise to act as both a process and a product. It aimed to develop plausible and decision-relevant scenarios of landscape change that could be utilized by other researchers and to help promote the shared learning, ownership of the scenarios, and capacity of practitioners to plan for and adapt to multiple futures.

To accommodate the explorative scenario approach and the long timeframes of ecological change in New England forests, we selected a 50-year timespan (from 2015 to 2065) for the scenario project. This provided a time horizon that challenged participants to think beyond conventional planning time scales and allowed people to see the consequence of their decisions in these slow moving systems.

cocietal issues.

Achieving these goals involves a multiphase process (Appendix 1), and we report primarily on the lessons learned from the initial scenario development phase of the project. The next phase of the project involves the modeling and analysis of the consequences of these stakeholder-developed land-use scenarios for ecosystem services and is still in progress and a planned "scenario application" phase that involves engaging with stakeholders to use the simulation results to collaboratively design and implement shared strategies for sustainable land use is still in development. A summary of the NE-LFP's goals and problem context is provided in Table 1.

\section{COLLABORATIVE DESIGN PROCESS AND OUTCOMES}

Codesign of the scenario development process

The design of any scenario exercise requires decisions about a number of process variables, including the type of scenarios, degree and form of stakeholder involvement, desired complexity, use of qualitative and/or quantitative methods, and the techniques that will be used to generate the scenarios (van Notten et al. 2003, Börjeson et al. 2006, Rounsevell and Metzger 2010).
Our aim in codesigning the scenario development process was to tailor the activities and approach to the stated preferences of stakeholders and scientists who were likely to be involved in the project based on their knowledge of the local context and research needs. Our specific process objectives for scenario development were to: (1) design a scenario development process that strengthened support for the process and outcomes by relevant stakeholders and institutions to promote the uptake and use of the results, (2) elicit plausible and decision-relevant scenarios of landscape change at the regional scale with sufficient detail for modeling and analysis, and (3) build the capacity of practitioners to plan for and adapt to multiple futures and the capacity of researchers to coproduce knowledge with stakeholders. It is worth noting that these process objectives cut across each of the three main dimensions of scenario use, i.e., (1) scientific exploration and research, (2) education and capacity building, and (3) decision support and strategic planning, and demanded the design of a process able to balance the different and sometimes competing scenario exercise elements involved (e.g., Henrichs et al. 2010, Kunseler et al. 2015). 
The codesign process took place over 10 months in 2014-2015 and incorporated input from relevant stakeholders and scientists through an iterative process that combined workshops, semistructured interviews, and open-ended conversations. This approach is reflective of other codesign applications reported on in the literature (e.g., Mauser et al. 2013, Binder et al. 2015, Reyers et al. 2015, Iwaniec et al. 2016, Page et al. 2016). Codesign activities were conducted as part of implementing the broader $\mathrm{S}^{3}$ $\mathrm{RCN}$ program and aimed to inform both the scenario development process and to help establish a shared problem framing and research objectives for the NE-LFP. Participants were identified via a purposive snowball approach that drew on the knowledge and contacts of the core network of $S^{3} \mathrm{RCN}$ collaborators (Creswell and Plano Clark 2007, Foster et al. 2014) and that was geared toward building a community of practitioners, scientists, and policymakers (in line with the aims of the $\mathrm{S}^{3} \mathrm{RCN}$ network). The results of this purposive snowball sampling were consolidated using stakeholder mapping along axes of interest and influence (Bryson 2004) and used to inform stakeholder selection for the (1) initial design workshop, (2) interviews, and (3) scenario development workshops. Invited stakeholders could determine their preferred level of involvement, including receiving products derived from the project, participating in scenario development workshops, hosting workshops as partner organizations, and participating as full collaborators actively involved in shaping the ongoing research and engagement efforts.

The codesign process began with a two-day workshop that brought together 35 researchers and stakeholders from across New England with the intent of developing a shared understanding for how best to apply scenario development toward the coproduction of actionable science for use in informing sustainable land-use policy, planning, and stewardship in the region. Attendees at the initial codesign meeting were selected to provide a balance of stakeholders, researchers, and experienced scenario practitioners who could provide insights about challenges and best practices in conducting participatory scenario processes. Activities at the workshop were structured with the intent of facilitating knowledge exchange, building relationships and trust between scientists and stakeholders, and enhancing collaborative capacity (Lemos and Morehouse 2005, Godemann 2008, Cockburn et al. 2016). They included presentations by stakeholders and scientists, panel discussions, facilitated dialogue, small working group sessions, informal conversations, and training sessions. The first day of the workshop focused on establishing a shared knowledge base around (1) the process of conducting transdisciplinary research and determining what "success" looks like from the point of view of stakeholders versus scientists (e.g., Lang et al. 2012), and (2) the application of participatory scenario processes to inform transdisciplinary research and the challenges involved, as informed by the perspectives and recommendations of experienced scenario practitioners (Table 2). The second day of the workshop built on this knowledge foundation and focused on refining a vision for the role of the NE-LFP and for how participatory scenarios research could be used to address the specific land-use challenges facing New England.
Table 2. Challenges to implementing a successful participatory scenario development process identified during the initial codesign workshop.

\begin{tabular}{|c|c|}
\hline Key challenge & Illustrative examples \\
\hline $\begin{array}{l}\text { Scientists and stakeholders } \\
\text { have different and } \\
\text { sometimes competing } \\
\text { needs, motivations, and } \\
\text { cultures that must be } \\
\text { balanced }\end{array}$ & $\begin{array}{l}\text { Scientists and stakeholders operate on } \\
\text { different timelines, with different languages } \\
\text { and outputs desired. } \\
\text { Stakeholder emphasis on local relevance } \\
\text { versus research needs of scientists. } \\
\text { Often need to balance scientists' } \\
\text { information needs with respecting } \\
\text { stakeholders' expertise and time } \\
\text { limitations. }\end{array}$ \\
\hline $\begin{array}{l}\text { Developing plausible and } \\
\text { nuanced scenarios is time- } \\
\text { consuming }\end{array}$ & $\begin{array}{l}\text { Scenarios involve an unfamiliar way of } \\
\text { thinking that can sometimes be } \\
\text { uncomfortable or confronting for } \\
\text { participants. } \\
\text { Scenario development requires integrating } \\
\text { diverse types of knowledge. } \\
\text { Achieving the desired shift in thinking is } \\
\text { usually a time-consuming and challenging } \\
\text { process, which needs to be balanced against } \\
\text { not overstepping the time requirements of } \\
\text { stakeholders. }\end{array}$ \\
\hline $\begin{array}{l}\text { Active sustained } \\
\text { engagement is important } \\
\text { for building ownership } \\
\text { over the process and } \\
\text { support for the outcomes }\end{array}$ & $\begin{array}{l}\text { The closer scenario development processes } \\
\text { are linked to the actual actors involved, the } \\
\text { more likely they are to generate relevant } \\
\text { insights, and result in successful uptake and } \\
\text { action. } \\
\text { Much of the learning and benefit from } \\
\text { codesigned science may come from } \\
\text { building trusting relationships between } \\
\text { scientists and practitioners. }\end{array}$ \\
\hline $\begin{array}{l}\text { The willingness of } \\
\text { stakeholders to commit } \\
\text { time is tied to the degree } \\
\text { to which the exercise is } \\
\text { linked to real, impactful } \\
\text { decisions }\end{array}$ & $\begin{array}{l}\text { There is often a gap between the long-term } \\
\text { focused outputs of scenario exercises and } \\
\text { their immediate relevance for decision } \\
\text { making. } \\
\text { Often a lack of opportunity to implement } \\
\text { strategic change within existing planning } \\
\text { cycles and organizational requirements. }\end{array}$ \\
\hline
\end{tabular}

The initial blueprint for the scenario development process established at the workshop was further refined over a period of several months via informal stakeholder consultation and an additional 57 semistructured interviews conducted with stakeholder representatives identified from each of the six states (three of which were also attendees at the initial codesign workshop). As with the workshop, the goal of the interviews was improving understanding of both stakeholder preferences regarding scenario development and process outputs as well as their knowledge and concerns surrounding the future of land use in New England. On the basis of the workshops and stakeholder consultations, the broad form that the scenario development process would take was established: a one day workshop held in each state to develop explorative, plausibility-based scenarios, with stakeholders driving the initial scenario development from scratch and remaining actively engaged throughout the process (i.e., Table 3, decisions 1-6). The reasoning that drove each of these decisions will be outlined in greater detail in the next section. To avoid placing undue demands on the stakeholders' time, the core research team, drawing on both the stakeholders' inputs and 
Table 3. Decisions and trade-offs made during the New England Landscape Future Project (NE-LFP) scenario development process.

\begin{tabular}{|c|c|c|c|}
\hline Decision & Trade-offs & NE-LFP decision & $\begin{array}{l}\text { Insights from implementation: strengths and weaknesses in } \\
\text { relation to trade-offs }\end{array}$ \\
\hline $\begin{array}{l}\text { 1. Type of } \\
\text { scenarios }\end{array}$ & $\begin{array}{l}\text { Supporting a specific decision context versus } \\
\text { invoking more explorative and transformative } \\
\text { thinking. }\end{array}$ & $\begin{array}{l}\text { Exploratory } \\
\text { scenarios }\end{array}$ & $\begin{array}{l}\text { The use of exploratory scenarios did not undermine the } \\
\text { perceived usefulness of the process and stakeholders rated } \\
\text { the resulting scenarios as having relevance for their work. } \\
\text { However, it was difficult to avoid normative influences in } \\
\text { developing the exploratory scenarios. }\end{array}$ \\
\hline $\begin{array}{l}\text { 2. Duration of } \\
\text { the participation } \\
\text { process }\end{array}$ & $\begin{array}{l}\text { Balancing stakeholders' time commitment with } \\
\text { (1) maximizing stakeholder involvement in the } \\
\text { process, (2) providing enough time to grapple } \\
\text { with challenging nature of the thinking } \\
\text { involved in building scenarios for research, and } \\
\text { (3) providing enough time for stakeholders to } \\
\text { develop trust and a shared understanding of } \\
\text { the problem. }\end{array}$ & One-day workshop & $\begin{array}{l}\text { Some refinement was necessary initially, but the codesign } \\
\text { approach was successful in developing a robust, intense, and } \\
\text { abbreviated process that produced the required outputs and } \\
\text { was mostly well-received by stakeholders. Additional time } \\
\text { would likely have been beneficial, however, because } \\
\text { attempting to develop appropriately divergent and nuanced } \\
\text { scenarios in one day was challenging. }\end{array}$ \\
\hline
\end{tabular}

3. Approach to Maintaining relevancy to stakeholders and plausibility

4. Spatial scale for scenarios and the scenario development process

5. Qualitative or quantitative scenarios

\section{Dividing} participation and responsibilities between stakeholders and scientists

\section{Deductive versus inductive process} specific decision contexts versus invoking more explorative and transformative thinking; challenging (and sometimes uncomfortable) nature of envisioning very different and perhaps idiosyncratic futures versus the need to find common areas of concern and not make too many incursions on stakeholders' time.

Focused on developing plausible scenarios

The developed scenarios appeared to be broadly accepted as plausible. The use of the structured scenario matrix approach helped to promote divergent thinking. However, even apart from the absence of discontinuities or shocks, the developed scenarios failed to deviate as much from projections of recent trends in some areas as would have been desirable (at least from the research teams' perspective).$$
\text { Challenging nature of envisioning very }
$$

Local relevance for stakeholders versus the needs of scientists and scale of impact for research.

Engage stakeholders at local level (state) and combine to regional (New England wide) level resto for simulation work
Accessibility to stakeholders versus scientific credibility and the needs of scientists; time required of stakeholders and scientists versus faithfully and transparently representing the stakeholders' input; potential for reduced interaction and engagement given stakeholders often have less ability to engage with the modeling process.

Balancing stakeholders' time commitment, expertise, and level of engagement with scientific credibility and information needs of researchers.

different futures versus the need for time- and engagement-intensive processes.

Combined qualitative and quantitative scenario approach using the "Story and Simulation" approach

Engage stakeholders throughout the full scenario development process

Deductive process

Intuitive logics two-axis/matrix Accessibility to stakeholders versus scientific credibility and the needs of scientists; challenging nature of envisioning very different approach futures versus the need for time- and engagement-intensive processes.
The state-based scenario workshops were highly valued by stakeholders. However, the need to synthesize the results has complicated the projects' research aims. Merging may have reduced some of the novelty and detail present in the individual states scenarios. The stakeholders judged the regionalization process and outputs as valid, though were
particularly interested in seeing local versions developed.

The translation stage of the workshop was broadly successful in providing guidance to inform the subsequent simulation stage. However, stakeholders found this stage to be challenging in the time permitted and additional input from scientists was necessary to complete the narrative to simulation translation. Requesting semiquantitative inputs may have pushed stakeholders too far beyond their expertise and could possibly have been better handled by scientists. Active involvement throughout the process appeared to help build understanding and support for the scenario exercise outputs. However, many stages of the development process were rushed and would have benefited from more time. Stakeholders at times felt they lacked the knowledge required to develop credible scenarios. This problem was particularly acute for the step requiring translation of the narratives to semi-quantitative estimates.

The deductive, highly structured process was instrumental in ensuring scenarios were able to be developed in one day from scratch and acted as a platform to support divergent thinking. However, there was limited time for more out-ofthe-box brainstorming, and the use of deductive causal reasoning may have allowed some existing biases and assumptions to remain unchallenged.

The process was accessible and engaging for stakeholders and able to be implemented within a one-day timeframe. Some refinement was necessary over the first few workshops to better balance efficiency against thoroughness (e.g., achieving comprehensive stakeholder input and consensus around the scenario matrix in a short amount of time). Comparison across states suggests that the axes did heavily frame the resulting scenarios. There was a tendency for the axis extremes to be associated with normative preferences (e.g., good/bad futures along each axis). 
the knowledge and resources available in the scenario planning literature, then developed scenario development materials within this broad process framework.

\section{Codesign process decisions}

Collaborative design is an iterative, nonlinear process (Lemos and Morehouse 2005, Sarkki et al. 2015) and rather than attempting to document the decision process in its entirety, we instead focus on detailing several high-priority decisions that strongly influenced the final process. This means that although the decision descriptions that follow may suggest a segmented, sequential process, in practice the design process proceeded in a more iterative fashion, with interactions and overlap present between several of the decisions (e.g., Pahl-Wostl 2008, Henrichs et al. 2010). We framed each focal decision in terms of its relevance to the challenges that exist in the application of foresight-based tools, like scenario planning, within a participatory process aimed at management and policy impact (Table 3). For each decision, we also focused on highlighting the broad trade-offs involved and the major classes of scenario techniques that were considered for each decision rather than listing all possible options, which given the multitude of scenario development techniques available would be impractical (e.g., Bradfield et al. 2005, Bishop et al. 2007).

\section{Decision: type of scenarios}

Key trade-offs: supporting a specific decision context versus invoking more explorative and transformative thinking.

The term "scenario" encompasses multiple types of hypothetical futures, most commonly differentiated in terms of whether they inspire normative (what do we want to happen?), exploratory (what may happen?), or predictive (what will happen?) styles of thinking (see van Notten et al. 2003 for more details on the different types of scenarios that exist). Normative scenarios are usually concerned with directly supporting decision making. They are used to examine possible paths for reaching different desired futures to help identify suitable policy options. Not all scenarios need be directly decision focused, however. Scenarios can also act as powerful tools for exploring more general possibilities, and exploratory scenarios can act as a backdrop for strategic conversations that can help to challenge and sharpen the mental models of stakeholders by generating new ideas and insights into the way societal and environmental processes influence one another (van der Heijden 1996). Approaches that combine explorative scenarios with a normative back-casting or policy exploration stage are also gaining traction as a means for coupling the exploration of long-term plausible futures with their implications for short-term (normative) decision making (e.g., Kok et al. 2011, Vervoort et al. 2014).

For the NE-LFP, we opted for a combined approach: developing explorative scenarios along with a planned application stage in which the scenarios would be used as tools to explore alternative decision strategies for achieving sustainable land-use outcomes. Focusing the initial development stage on explorative rather than normative scenario development suited the NE-FLP's objective for developing the capacity of participants to envision and adapt to multiple futures. Given the multiple and diverse actors influencing land-use decisions in the region, developing a single set of normative scenarios equally relevant to all parties in the time provided would have been challenging. In particular, we lacked a strong enough authorizing environment (e.g., commissioning of the study by a public agency) across the region to allow for the development of normative scenarios that would be widely perceived as having adequate legitimacy. However, this choice to focus on strategy exploration at a subsequent stage in the NE-LFP meant forgoing the more immediate decision relevance that a normative scenario exercise can provide during scenario development (Rounsevell et al. 2012). This left a higher barrier to overcome in establishing the utility, and thus the relevancy and saliency, of long-term exploratory scenarios for stakeholders during this first stage of the engagement process.

\section{Decision: duration of the participation process}

Key trade-offs: balancing stakeholders' time commitment with (1) maximizing stakeholder involvement in the process, (2) providing enough time to grapple with the challenging nature of the thinking involved in building scenarios for research, and (3) providing enough time for stakeholders to develop trust and a shared understanding of the problem.

Within scenario research, the time-consuming nature of a scenario development process has been identified as one of the key challenges to successful implementation (Rickards et al. 2014). Time is required for those involved in the scenario development process to establish trust and build relationships and to develop a shared understanding of the problem, an issue often further heightened by the diverse actors and epistemologies involved (Polk 2015, Reyers et al. 2015, Vervoort et al. 2015, Bennett 2017). Although higher levels of active participation are usually linked to higher levels of engagement and more useful and influential outputs (e.g., Newig and Fritsch 2009, Evely et al. 2011, Clark et al. 2016, Posner et al. 2016), requiring too much time can restrict the ability of stakeholders to participate and may also limit the diversity of stakeholders engaged (Polk 2015). This is especially true of stakeholders for which the scenario project does not fall directly within the purview of their day-to-day tasks and in which the process is not specifically linked to policy development or decision making, as with the NE-LFP (and further heightened by the choice to pursue explorative rather than normative scenario development).

In designing our scenario development process, one of the key guidelines communicated during the initial consultation workshop was to be mindful of not overextending the time commitments being asked of stakeholders and risk limiting their ability to participate. To address this, we reached out to different stakeholder groups and received feedback that a one-day workshop was regarded as the maximum time commitment it was appropriate to ask stakeholders to make. The resulting challenge for the NE-LFP was then how to ensure strong, meaningful engagement with a large, diverse group of stakeholders when working within such a limited time period.

\section{Decision: approach to plausibility}

Key trade-offs: maintaining relevancy to stakeholders and specific decision contexts versus invoking more explorative and transformative thinking; challenging (and sometimes uncomfortable) nature of envisioning very different and perhaps idiosyncratic futures versus the need to find common areas of concern and not make too many incursions on stakeholders' time.

Scenario practices encompass techniques for developing probable, plausible and/or possible futures (Wilkinson 2009). 
Plausibility-centric approaches, i.e., the more widely used approach in participatory environment applications, aim to articulate multiple alternative futures in a way that explores the limits of possibility rather than make any attempt at forecasting the future (Bishop et al. 2007, Ramírez and Selin 2014). The tendency of people to perceive the future as being largely like the past (Bryson et al. 2016), however, means that relying on preconceptions of what is plausible can be problematic (Ramírez and Selin 2014). An important part of scenario work thus lies in "stretching" thinking about the future by widening the range of possibilities considered plausible (Wright et al. 2013, Bryson et al. 2016). This reperceiving (Wack 1985) must be carefully balanced against the risk of scenarios being deemed too uncomfortable, implausible, or pessimistic to be relevant (Schwartz and Ogilvy 1998).

A variety of approaches can be used to stretch participant thinking beyond standard conceptions of the future. For example, incorporating "shocks" or discontinuities (e.g., Carpenter et al. 2015, Daw et al. 2015) is often seen as one way of achieving a very high level of divergence from existing assumptions about the future (van Notten et al. 2005), in which shocks are usually understood as being significant changes that depart qualitatively from one's expectations about a phenomenon and what is actually observed. Less extreme options for pursuing the development of divergent scenarios also exist, such as with the widely applied scenario matrix method (e.g., Schwarz 1991, van Notten et al. 2003). Alternatively, Ramírez and Selin (2014) and others have argued for refocusing scenario development around maximizing discomfort and uncertainty to widen perceptions of what is plausible, rather than around strict scenario divergence.

Given that the more divergent scenarios are, the less plausible and thus less relevant to end-users they may be perceived to be, approaches that really push beyond current perceptions of the future may only be suitable when there is sufficient time for deep reflection and exploration (Vervoort et al. 2015). For the NE-LFP, we opted not to explicitly strive for extremely divergent scenarios or to incorporate exercises to generate shocks for inclusion in the scenarios, but instead chose to focus on encouraging participants to embrace uncertainty, discomfort, and to recognize contrasting perspectives about what the future might hold (e.g., across different stakeholder groups). This decision was made in response to feedback received from stakeholders about the types of scenarios they considered most relevant, and were therefore most likely to use and implement. We were also mindful of the time constraints, which meant that more extreme approaches to pushing stakeholders to extend their thinking beyond existing conceptions of plausibility were not necessarily suitable.

Decision: spatial scale for scenarios and the scenario development process

Key trade-offs: local relevance versus needs of scientists, and scale of impact for research.

The spatial scale for a scenario exercise, from local, to regional, to global, is recognized as being of particular concern in the design of participatory scenario processes (Biggs et al. 2007, Henrichs et al. 2010). The choice of spatial scale for a scenario analysis influences the nature of the processes and relationships within social-ecological systems that can be represented. Whether scenarios can be put to effective use is also often a question of whether the scenarios address and display trends at an appropriate scale, that is, the level of interest and relevance to the intended audience or political decision makers (Kok et al. 2017). As such, a tension often arises in environmental assessments between the desire to capture multiscale ecosystem processes and the benefits of tailoring a scenario exercise to particular contexts to address local heterogeneity and enhance relevancy for local stakeholders. Increasingly, multiscale approaches that link scenarios across different geographical scales are being used to reconcile these competing demands, thus enabling the representation of multiscale social-ecological dynamics and allowing for greater saliency across key stakeholders at multiple scales (Zurek and Henrichs 2007, Alcamo 2008b). Options for the development of multiscale scenarios can range considerably, from iterative to sequential processes, and via top down (regional scenarios contextualizing local scenarios) or bottom up (local scenarios informing regional scenarios) approaches. The resulting multilevel scenarios can be either loosely or tightly coupled, depending on project demands, development style, and the feasibility of linking variables and processes across different scales (see Zurek and Henrichs 2007 for more on the different degrees of scenario linkage that are possible). Despite the benefits that multiscale methods can provide for environmental scenario assessments, their use entails a greater investment of time and resources and must be managed carefully to avoid the risk of reduced relevance at any individual scale.

For the NE-LFP, although the scientific aims of the project necessitated a region-wide perspective, the feedback we received from stakeholders was that as a region dominated by "home rule," i.e., strong local governments, and in which most stakeholders operate within state boundaries, engagement at the state rather than New England-wide level would be important for ensuring local relevance and credibility. An additional consideration was the level of variation across New England from state to state and the fact that a state-based scale was more cognitively manageable for participants and would be better able to draw on their specific knowledge and insights.

To balance these concerns against the broader scientific aims of the project, a decision was made to use a bottom up multilevel approach and develop a set of coordinated state-based scenarios that would then feed into the development of a set of New England-wide scenarios. This led to a shift from the initial plan of holding two north and south New England workshops, to holding workshops in each of the six New England states, with the aim of then assimilating the developed state scenarios into a coherent region-wide scenario to meet the scientific requirements for the process. Although the option of providing stakeholders with a set of global/regional scenarios and then asking them to develop regional/local scenarios in response to these scenarios was considered, this was ultimately rejected over concerns that this would be too cumbersome for a one-day process, and it was also thought that stakeholders might be less willing to accept and work within the constraints of a set of predeveloped scenarios.

\section{Decision: qualitative or quantitative scenarios}

Key trade-offs: accessibility to stakeholders versus scientific credibility and the needs of scientists; time required of stakeholders and scientists versus faithfully and transparently representing the stakeholders' input; potential for reduced interaction and engagement given stakeholders often have less ability to engage with the modeling process. 
Techniques for depicting scenarios range from non-numerical qualitative descriptions, like stories and pictures, through to methods involving the extensive use of quantitative and computational tools. Combinations of both qualitative and quantitative techniques are also common (Alcamo 2008b). Quantitative representations deal with numerical information and allow for the explicit representation and testing of underlying assumptions. They are often an important part of scenario work aimed at scientific audiences. However, although using models provides many advantages, their use can also reduce the transparency of scenario outputs to nonscientists and restrict the kinds of issues that can be explored. Qualitative scenarios, in contrast, have the advantage of being easily accessible to stakeholders. Not requiring representation with models also potentially allows for more creative, unrestricted thinking and for representing the views and complexity of many different interests (van Vliet et al. 2012, Freeth and Drimie 2016). Combination "Story and Simulation" style approaches aim to capitalize on the strengths of each format, though at the cost of a lengthier process, and the need to balance the input requirements and constraints of the selected quantitative approach with the need to be transparent and faithful to the underlying scenario descriptions. Although a variety of methods for this exist (Mallampalli et al. 2016), successful translation is ultimately best accomplished through a process that involves multiple iterations between scientists and stakeholders (Alcamo 2008c). Tensions thus arise between the time constraints of the broader process, the complexity of the selected modeling and translation process, and the need to adequately maintain stakeholder understanding of and engagement with the process.

For the NE-LFP, a combination Story and Simulation approach was chosen to help meet the needs of both a research driven process using complex land-use models to explore the implications of different futures for landscape features, such as ecosystem services, and of a successful participatory process that engages and involves stakeholders throughout. In particular, given the desire to make use of an existing framework of landcover change, ecosystem processes, and ecosystem services (sensu Blumstein and Thompson 2015, Thompson et al. 2016), there was a desire to involve stakeholders at a level that was commensurate with their experience and interests. For the translation step, we opted to involve the stakeholders directly in translating their initial qualitative scenarios into semiquantitative estimates for the set of land-use model inputs during the planned one-day workshops. To help ground their quantitative estimates in science, stakeholders were first provided with relevant information on recent land-use trends in their state. The use of a simple worksheet (see Appendix 2) then allowed participants to specify their estimates in a variety of ways, i.e., numbers, arrows, drawings, words (whichever suited them best), helping to maximize the accessibility of the translation process for stakeholders and foster their continued ownership over the subsequent quantitative translations.

\section{Decision: dividing participation and responsibilities between} stakeholders and scientists.

Key trade-offs: balancing stakeholders' time commitment, expertise, and level of engagement with scientific credibility and the information needs of researchers.
Determining in which stages of the scenario development that stakeholders will take part in and how and which will be completed by the research team is distinct from decisions regarding the duration of the engagement process. It is not uncommon, for example, for researchers to opt to develop initial draft scenarios that are then provided to stakeholders for review and refinement, or alternatively for a process to engage with stakeholders to elicit their knowledge and concerns regarding possible futures, but for the research team to be responsible for scenario construction based on this initial stakeholder input (e.g., Carpenter et al. 2015). Although high levels of stakeholder interaction are encouraged in scenario development (e.g., Schwartz and Ogilvy 1998, OterosRozas et al. 2015), in many instances this must be balanced against the time-intensive nature of developing scenarios and the desire to incorporate scientific knowledge and tools (e.g., Volkery et al. 2008, Bohensky et al. 2011).

Given the recommendations from the initial planning workshop and the aims of the NE-LFP, the direct and ongoing involvement of stakeholders was treated as a priority to ensure maximal stakeholder engagement and ownership of the outcomes. This resulted in a decision to aim for a process that that would walk the stakeholders through the full scenario development process from "empty page" through to semiquantitative descriptions of four scenarios. The desire to enhance the transparency of the scenario modeling stage motivated a choice to involve the stakeholders in translating their initial qualitative scenarios into semiquantitative estimates for input into the set of land-use models. In addition, postworkshop webinars were planned as a means of keeping the stakeholders engaged and involved in the complete scenario development and translation process.

\section{Decision: deductive versus inductive process}

Key trade-offs: challenging nature of envisioning very different futures versus the need for a time- and engagement-intensive process.

A wide variety of approaches exist for developing plausibilityfocused scenarios (van Notten et al. 2003, Bishop et al. 2007), among which a key distinction lies in whether they enlist deductive (general-to-specific) or inductive (specific-to-general) techniques for identifying the focal uncertainties and plot lines around which the scenarios will be based, a.k.a. the scenario logic (e.g., van der Heijden 1996, Schwartz and Ogilvy 1998, Davis 2002). Deductive processes develop scenarios via a general framework by first identifying the most influential and uncertain drivers of future change and then structuring scenarios around these critical uncertainties to deduce the scenarios. Such an approach provides a platform to support divergent thinking and ensures that appropriately distinct and variable scenarios are developed. In contrast, inductive approaches are much more open-ended and exploratory, with the scenarios emerging from in depth discussions about individual events or plot elements, around which larger scenario storylines are then developed organically (Gallopín and Rijsberman 2000). By building scenarios around individual plot elements relevant to the particular case study, this approach has the potential to yield compelling plot lines with direct links to relevant strategic decisions in the present (van Vliet et al. 2012, Bowman et al. 2013). However, the unstructured nature also results in a process that is both more opaque and more reliant on the creativity and imagination of the participants; in turn driving 
greater time and facilitation demands to ensure success (Volkery and Ribeiro 2009).

For the NE-LFP, the preworkshop interviews with stakeholders revealed a lack of obvious candidates for key drivers of change or plot elements around which to build up scenarios, creating concern that an inductive process would fail to generate enough divergence. In addition, the time constraints and need to eventually integrate the state-based scenarios into New Englandwide scenarios suggested that a structured, repeatable process yielding comparable results would be advantageous. These reasons led to the decision to proceed with a highly structured, deductive style approach, wherein the step-by-step nature of the process would act as scaffolding around which appropriately divergent scenarios could be developed. Such a choice also allowed for the balancing of the need to maximize stakeholder engagement in the process and develop group derived state level scenarios from workshop participants with the need to accomplish the scenario development process within a one-day workshop. Moreover, the structured nature of the process made it easily replicable across the six state workshops so that each workshop generated similar outputs that could then be combined into a single New England-wide scenario set through a logical and transparent process.

\section{Decision: choice of scenario development method}

Key trade-offs: challenging nature of envisioning very different futures versus the need for a time- and engagement-intensive process; balancing stakeholders' time commitment, expertise, and level of engagement with scientific credibility and information needs of researchers.

The vast majority of environmental scenario assessments are derived from the intuitive logics (IL) school of scenario development, though a variety of alternative methodologies for scenario development outside this school also exists (Bishop et al. 2007, Amer et al. 2013). The intuitive logics model is a plausibility-based approach that enables participants, usually within a workshop setting, to create narratives describing unfolding causal processes, resulting in a set of distinct, alternative possible future worlds. Its popularity stems from its accessibility, providing a good mix of sophistication and ease of use for both project organizers and process participants (Wright et al. 2013, Bowman 2016). Its flexibility also lends itself to a wide range of scenario purposes and allows for easy adaptation to a wide variety of contexts. By far the most common instance of IL approach is the deductive-style two-axis/matrix approach developed and popularized by Royal Dutch Shell/Global Business Network (Bradfield et al. 2005). This approach constructs scenarios around two drivers with two extreme states each, resulting in a set of four divergent scenarios that aim to explore the limits of possibility (Schwarz 1991, Rounsevell and Metzger 2010).

Despite its widespread use, there are a number of drawbacks associated with the two-axis/matrix approach. The imposition of a 2 x 2 matrix and axes extremes can drive unnecessary polarization in thinking, for example, and pre-emptively restrict exploration of the future possibility space to around only two uncertainty drivers (Wright et al. 2013, Parker et al. 2015, Bryson et al. 2016, Lord et al. 2016). These criticisms have spurred a growing body of tools for augmenting the standard IL approach, particularly through the use of quantitative decision support tools that can be used to enhance the choice of appropriately divergent scenarios and help counteract the potential shortcomings of purely judgment-driven methods for scenario development (e.g., Parker et al. 2015, Bryson et al. 2016). For example, methods such as morphological analysis (MA) and field anomaly relaxation (FAR) represent alternatives in which a greater number of alternative uncertainty states can be searched and considered (Bishop et al. 2007). However, they can also create additional decision-support complications (e.g., Parker et al. 2015) and are thus less commonly implemented despite their potential benefits (Bradfield 2008, Bryson et al. 2016).

For the NE-LFP, given our limited timeframe and preference for participatory-derived and plausibility-based deductive scenarios, we opted for a condensed version of the deductive two-axis approach from the IL school (Schwarz 1991, Van der Heijden 1996). It fitted well with our objective of maximizing stakeholder inclusion and engagement across a diverse range of participants, and our aims of developing a process that was engaging, creative, encouraged full participation and gave stakeholders authorship of their scenarios, while balancing this with the need to eventually arrive at quantitative scenarios that could be used to inform the simulation modeling. The designed process included the following stages: (1) introduction and orientation to the process, (2) identification of driving forces, (3) selection of key drivers, (4) development of the scenario matrix, (5) fleshing out of the scenario narratives, (6) presentation on recent trends, and (7) conversion of storylines to semiqualitative land-use change estimates for use in modeling (Fig. 1; Table 4).

Fig. 1. Stages in the scenario development process. For additional information about each of the stages refer to Table 4.

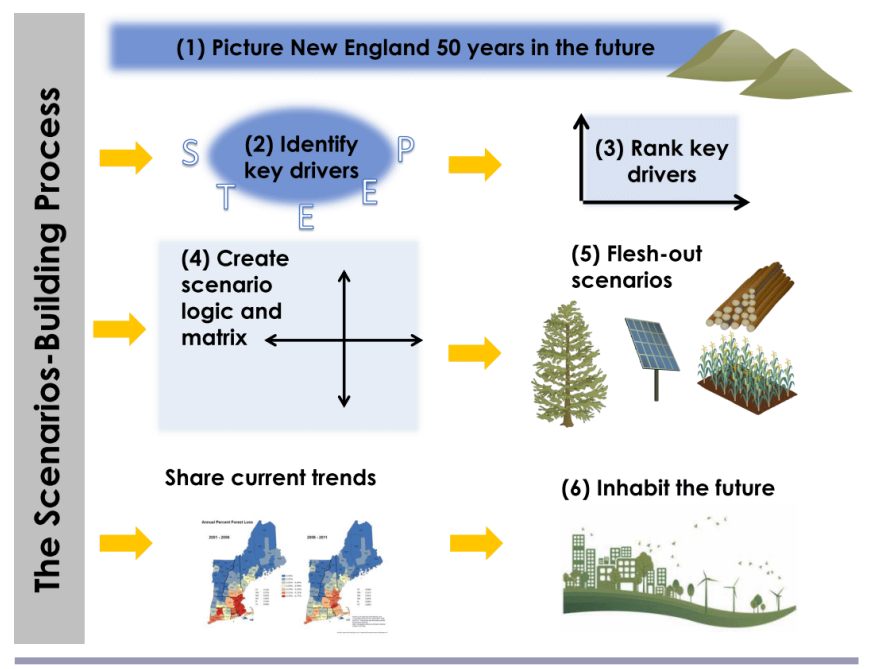

\section{Implementation of the scenario development process}

Scenario development workshops

The codesigned process was implemented through six scenario development workshops held during September-November 2015 and convened in each of the six New England states. At each 1day workshop, approximately 20-25 stakeholders were in 
Table 4. Six stage scenario development process employed during the stakeholder workshops.

\begin{tabular}{|c|c|c|c|}
\hline Stage & Description & Purpose & Details \\
\hline 1 & $\begin{array}{l}\text { View from the } \\
\text { mountaintop }\end{array}$ & Entryway into the process. & $\begin{array}{l}\text { Aims at getting individuals to think creatively and broadly about the } \\
\text { future. In this case, by asking what they expect to see across their } \\
\text { state's landscape "from a mountaintop" in } 2065 \text {. Visions were then } \\
\text { sharing in small groups to gel those groups and build collegiality, and } \\
\text { then shared with the larger group. }\end{array}$ \\
\hline 2 & $\begin{array}{l}\text { Identify driving } \\
\text { forces }\end{array}$ & Determine driving forces (drivers) for the region. & $\begin{array}{l}\text { Participants work, first individually, and then as a group, to identify } \\
\text { driving forces (key drivers of change that might shape how the region } \\
\text { changes over the next } 50 \text { years). }\end{array}$ \\
\hline 3 & $\begin{array}{l}\text { Rank and select } \\
\text { drivers }\end{array}$ & $\begin{array}{l}\text { Select the most uncertain and highest impact } \\
\text { drivers. }\end{array}$ & $\begin{array}{l}\text { Identified driving forces are first clustered into groups with related } \\
\text { themes by facilitators. For each driver group, the names and extremes } \\
\text { (poles) are then defined. They are then ranked by the group according } \\
\text { to how uncertain and impactful they are. }\end{array}$ \\
\hline 4 & $\begin{array}{l}\text { Develop scenario } \\
\text { matrix }\end{array}$ & $\begin{array}{l}\text { Develop } 2 \times 2 \text { scenario matrix with each axis } \\
\text { depicting a key driver of change. }\end{array}$ & $\begin{array}{l}\text { Chosen via discussion and voting by the group based on the } \\
\text { combination of drivers that are most interesting (i.e., divergent from } \\
\text { one another and both highly uncertain and impactful). }\end{array}$ \\
\hline 5 & Flesh out scenarios & Further scope out each scenario storyline. & $\begin{array}{l}\text { Participants working in four groups are each assigned one of the four } \\
\text { quadrants and then work to flesh out the broad conditions and } \\
\text { descriptions for their assigned scenario. }\end{array}$ \\
\hline Break & $\begin{array}{l}\text { Recent trends } \\
\text { presentation }\end{array}$ & $\begin{array}{l}\text { Provide background information on recent trends } \\
\text { in land-use change for New England. }\end{array}$ & $\begin{array}{l}\text { A short presentation that takes place after lunch. Included at this } \\
\text { stage of the process to inform the translation of scenarios from } \\
\text { qualitative to quantitative while not overly influencing scenario } \\
\text { development in the earlier stages of the process. }\end{array}$ \\
\hline 6 & Inhabit scenarios & $\begin{array}{l}\text { Translate qualitative scenarios into } \\
\text { semiquantitative estimates for use in land-use } \\
\text { simulations. }\end{array}$ & $\begin{array}{l}\text { Participants are asked to provide estimates of how scenario conditions } \\
\text { affect rates of development, farmland, land conservation, and forest } \\
\text { harvesting, and why. }\end{array}$ \\
\hline
\end{tabular}

attendance. These stakeholders differed from those attending the initial planning workshop (with the exception of 4 individuals in attendance at both) and overlapped partially with the stakeholders interviewed during the codesign process (16 of the stakeholders attending 1 of the workshops were also 1 of the 57 stakeholders interviewed, and 1 individual was represented at all 3 engagement activities). The 128 attendees were drawn from a mix of the private sector (e.g., real-estate development and forestry), government agencies, nongovernmental organizations operating in the region, and universities.

\section{Regional landscape scenarios generated by stakeholders}

As a result of following the process outlined in Figure 1, each state workshop resulted in a $2 \times 2$ scenario matrix, a set of four qualitative scenario outlines, and rudimentary quantification of the inputs required for the modeling stage of the project (Fig. 2; Appendix 2).

Combing the six sets of state scenario outputs into a single set of four New England-wide scenarios (i.e., regionalization) required a three-tiered approach: (1) aligning state matrices and merging driving forces to create a regional, overarching matrix; (2) integrating, and where necessary, resolving, characteristics across the six states for each of the four resulting scenario quadrants and using these to construct the regional scenario narratives; and similarly (3) aligning the results of the quantification stage across each state for each of the scenario quadrants. For step (1), the process of merging the individual state drivers to generate the regional, overarching drivers is summarized in Figure 3, and the resulting land-use change rates are summarized in Figure 4. This additional feedback led to a number of substantive revisions to the scenarios, including shortening of length, a greater focus on describing land-use change plot elements rather than socioeconomic developments, the addition of plot summaries, and editing for tone to reduce the perception of any one scenario being perceived as the favorite. The final scenario narratives are included in Appendix 3.

\section{Post-workshop feedback and iteration}

Following the workshops, two 90-minute interactive webinars were held (each with identical content) during April-May 2016 to provide feedback on the process of integrating the individual state scenario outputs into a combined set of four New England-wide scenarios and to engage the stakeholders again around the translation of the narratives into models. During the webinars, feedback on the integration process was solicited using interactive voting software, together with additional input on how to further flesh out the scenario narratives, the translation of the scenario narratives into models, and candidates for the regional scenario names. For the full list of interactive questions presented during the webinar see Appendix 4. This process acted as a second phase in which the stakeholders could take ownership of the scenarios and played a critical role in maintaining transparency and stakeholder engagement throughout the process of combining workshop outputs into a single set of regional scenarios and translating those storylines into rules for simulation. Results from the webinar voting and feedback were used to revise the scenario narratives and to further refine the process of translating the narratives to model simulations (Fig. 4, b). Following these revisions, a complete draft set of scenario narratives was circulated to the full stakeholder group for comment, continuing the cycle of iteration between stakeholders and scientists in the process of developing the scenarios. 
Fig. 2. The scenario matrices (i.e., axes and endpoints) developed at each of the six New England state workshops.

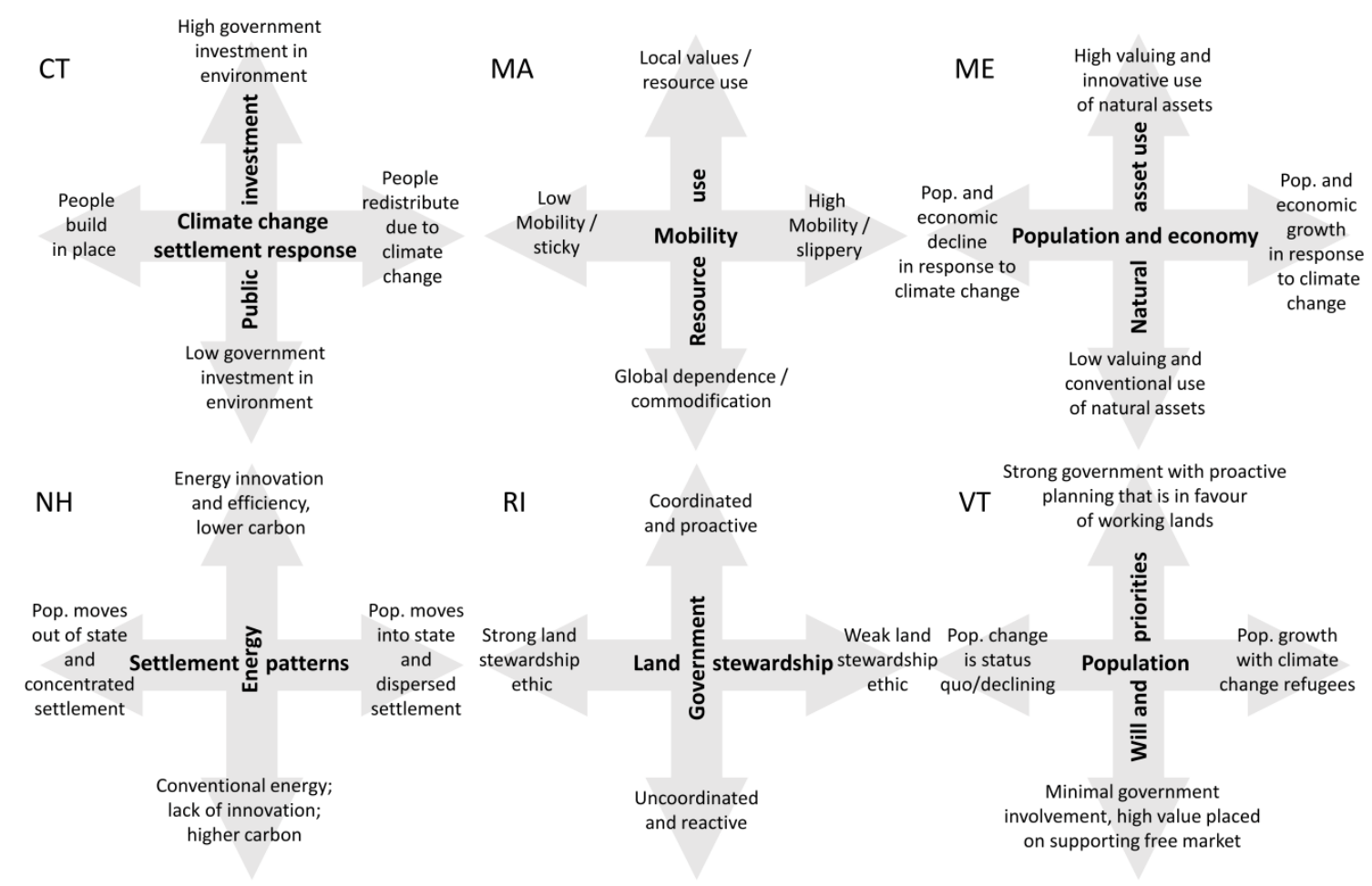

Evaluation of the scenario development process

The relative success of the scenario development process to date was assessed using the participant feedback collected after each of the six scenario elicitation workshops and during the webinars. We note however, that this evaluation gathers feedback at a relatively early stage in the overall process and perceptions may change as additional products are provided to stakeholders (Walter et al. 2007, Roux et al. 2010). Workshop evaluation forms asked participants to list what they had liked, learned, and would change about the process. We used qualitative content analysis to identify themes (Corbin and Strauss 2014) and then organized these in relation to the design trade-offs identified for scenario processes in Table 2.

Postworkshop evaluations suggested that most participants enjoyed the process and that it successfully walked participants through the scenario development process and expanded their thinking about the future. However, many comments also acted as a good illustration of the design trade-offs in action (Table 5). For example, although many participants commented favorably on the organized and efficient nature of the process, others commented that the process felt rushed at times and that more time to further develop the scenarios would have been useful. And although almost all participants reported finding the scenario building process useful as a structure for thinking more expansively about the future that managed to "...tease out an increased understanding" (Maine academic) and encouraged them "...to really think outside the present" (Rhode Island forester) and "...com[e] away with a broader spectrum of what the future look like" (Maine nonprofit director), there were also comments regarding the difficult nature of the task, and that for example, "...[it] was tough to wrap your arms around a 50-year scenario" (Vermont nonprofit director). Additional issues raised included concerns about the legitimacy of the process, "...[we] needed more diverse participants in the room" (Rhode Island land manager), about the credibility, ".... [it] seems like too much of a 'back of the envelope' approach on which to base detailed modeling" (New Hampshire nonprofit researcher), and saliency, "...more specifics on how to use this tool in my own organization on a day to day basis. And how this will be used by us in the future" (Maine nonprofit coordinator). Similar feedback was received from both stakeholders who did and did not take part directly in the codesign process, though codesign process participants did not raise any concerns over its relevancy for decision making (i.e., Table 5, row 1). Feedback collected during the webinar on the utility of the scenario products developed revealed that participating stakeholders $(n=26)$ saw the final regional scenario matrix as being relevant $(62 \%)$ or somewhat relevant $(35 \%)$ to their work (Table 6). Similarly, they reported the regional scenario storylines as being relevant $(69 \%)$ or somewhat relevant $(31 \%)$ to their work.

\section{DISCUSSION}

Importance of tailoring the scenario development process

In any scenario project, there are competing demands on the development process that must be balanced. With the New England Landscape Futures Project, we advanced a framework 
Fig. 3. Illustration of step (1) in the regionalization process, the merging of individual state matrices into a regional, overarching matrix. Crossed out text indicates those elements of the state matrices that were removed in resolving the individual state matrices into a coherent regional matrix.

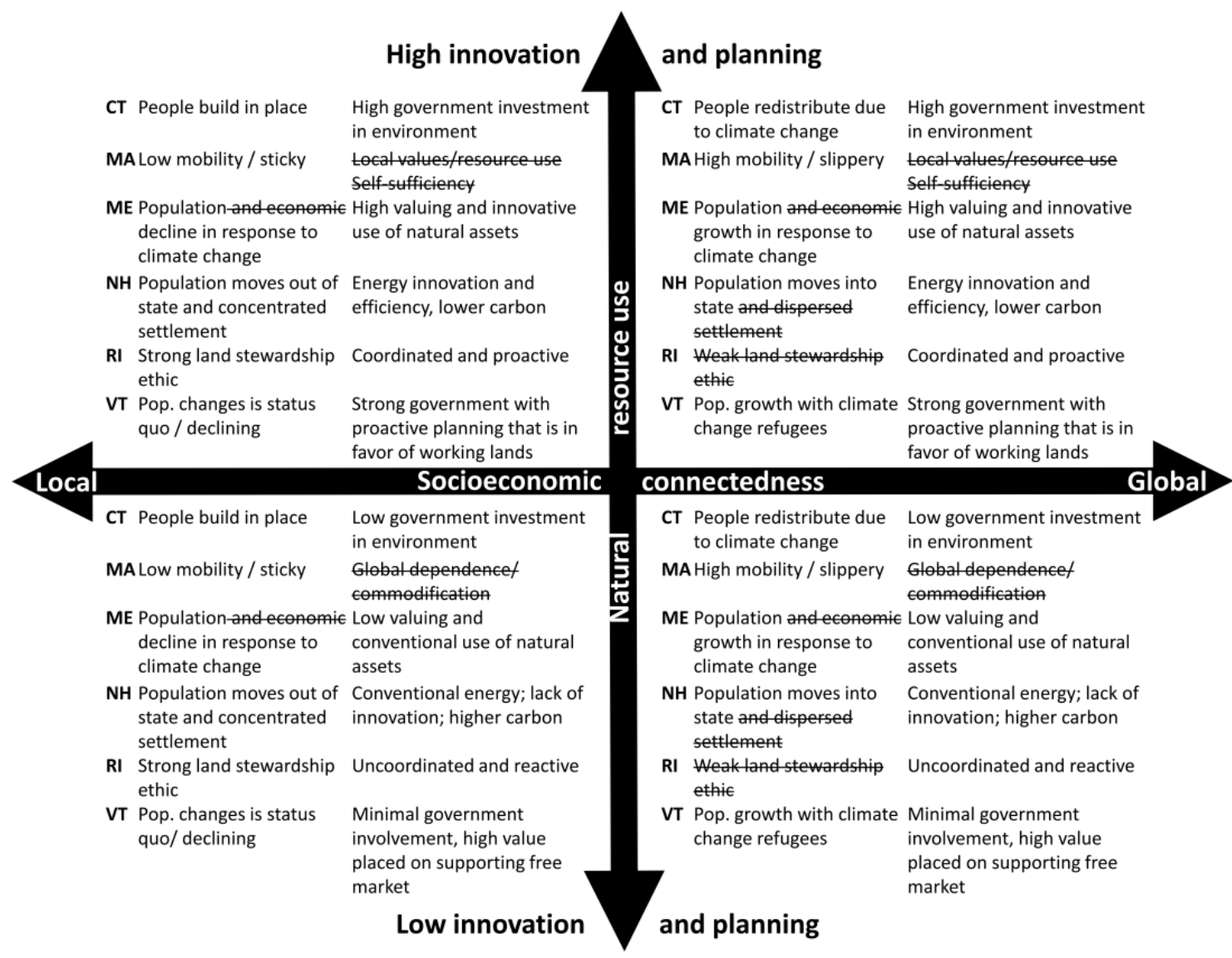

for codesigning a scenario development process and illustrated how the choice of scenario development techniques should follow from the project objectives, the problem context, and stakeholder preferences. As described in the codesign descriptions, the choice to be informed by stakeholder and scientists' preferences for a scenario building process influenced the type of scenarios developed, the duration and scale for engagement, the development stages in which stakeholders were involved, the style of scenario building process, and the outputs developed from the workshop (Table 3). Explicit attention to process design helped us to recognize and address the presence of important trade-offs in all participatory scenario processes, i.e., considerations such as (1) time efficiency and level of detail, (2) creative versus analytical thinking, and (3) striving for immediate policy relevance versus more long-orientated planning (Schoemaker 1998, Henrichs et al. 2010, Rounsevell and Metzger 2010, Kunseler et al. 2015, Cairns et al. 2016). Negotiating these trade-offs via a collaborative approach allowed us to design a process for eliciting divergent scenarios that satisfied the research needs of scientists while ensuring stakeholders could be involved throughout the full development process (Table 6).

For the NE-LFP, three priorities drove the majority of decisions made: constructing draft scenarios through a one-day process, engaging stakeholders in all steps of the scenario development process, and generating the information required by researchers. For other settings, a different set of core priorities will shape choices. The protocol implemented in Cairns et al. (2016), for example, was specifically designed to prioritize the ability of senior individuals from industry and government with very limited time availability to participate. This guided the development of an engagement process of three 90-minute workshop sessions with stakeholders in conjunction with the project team completing the bulk of scenario development outside the workshops. This is a different approach to ours, and one that was possible in part because of a stronger authorizing environment and more direct relevance to upcoming policy decisions, but the takeaway in both cases is that initial consideration of engagement objectives and constraints, followed by a deliberate and informed process of design that draws on the experiences and knowledge of the literature and the stakeholders and context, can usefully inform design decisions.

\section{The codesign product: strengths and weaknesses of the designed} process

For many planning contexts, the willingness of stakeholders to commit time is likely to be directly proportional to the relevance of the process and outcomes to their professional responsibilities. 
Fig. 4. (a) Original stakeholder estimates, and (b) adjusted rates of land-use change for each state in New England as a proportion of recent trends.

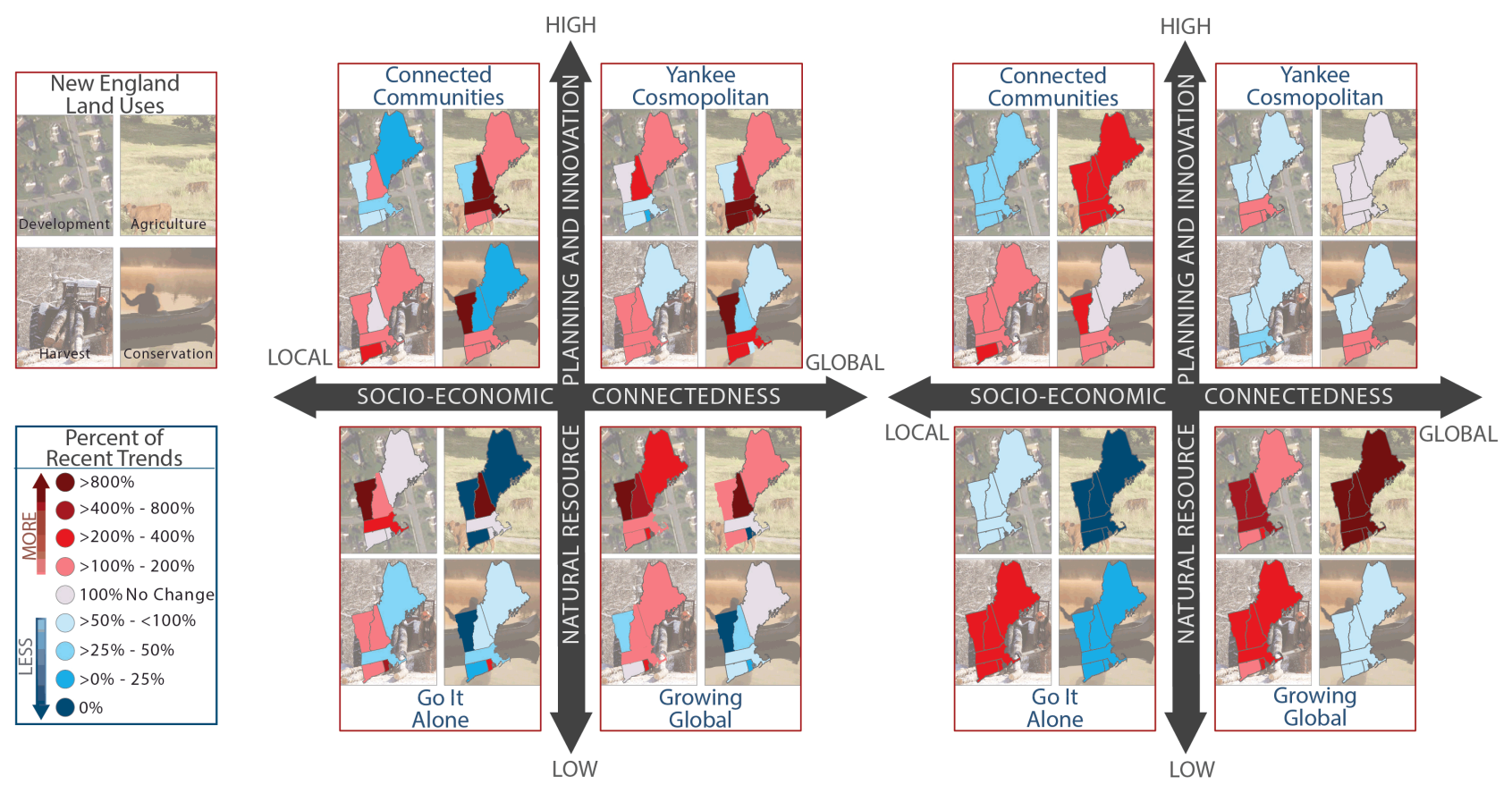

Erratum: This figure replaced the originally published version on 16 May 2018.

Thus, for the NE-LFP, characterized by a diffuse authorizing environment and a diverse set of stakeholders (Table 1), the codesign process led to the creation of a robust and highly structured one-day scenario development process that was mostly well received by stakeholders. Even the most well-planned and strategic processes, however, have limits to how well they can quickly develop divergent, nuanced scenarios with a group of diverse and inexperienced participants (Tables 2,3). We judge that although a one-day process was the correct choice for our project, more time would likely have permitted greater detail and nuance to be incorporated into the scenarios. Alternatively, given that the one-day process was a design priority, including fewer steps in the process and relying on the expertise of researchers to develop the first draft of the quantitative rules of the model simulation could have been a more productive use of stakeholders' time and interest.

Despite eliciting the required outcomes, implementation across the six workshops also revealed limitations to our scenario development process (Tables 3,5). Most notably, the choice to involve stakeholders in the initial translation of the qualitative narratives to quantitative inputs for use in the simulation was too much to ask. This stage in the process was geared at balancing the needs of the scientists with transparency and accessibility of the modeling stage for stakeholders. Although the outputs were able to inform the simulation models, stakeholders and facilitator feedback indicated that the inclusion of this quantification stage was challenging for stakeholders to perform in the time permitted. This was also the stage of the regionalization process for which the most revision was required to operationalize the stakeholder's inputs. Our conclusion was that asking stakeholders to develop semiquantitative estimates may have been pushing them too far beyond their experience, and that a better, equally legitimate approach would have had the scientists converting the storylines into model simulation rules, and then sharing their recommendations with the stakeholders for commentary. This perhaps reflects the importance of engaging individuals in the capacity through which they are best able to contribute and not trying to push them too far beyond that simply for the sake of participation.

Benefits of codesign for informing scenario process development To what degree does our case study support the use of codesign over more standard modes of scenario process design? A lack of a control study limits our ability to draw any strong conclusions. Nonetheless, one means by which we can explore potential benefits is by comparing stakeholder experiences with our process to that of stakeholder experiences in projects with less of an explicit focus on scenario codesign. A comprehensive review of feedback from participatory scenario studies is beyond our scope. However, Oteros-Rozas et al. (2015) reviewed experiences from 23 participatory scenario processes across a range of applications and acts as a good subsample of studies with which to make comparisons. The stakeholder feedback described across these 23 case studies revealed many commonalities with that received for the NE-LFP. For example, the most frequently cited concerns for the NE-LFP are common across participatory processes and not specific to our case study, such as the time required and the difficulties in compacting engagement processes into a one-day framework (e.g., Oteros-Rozas et al. 2015, Polk 2015, Cockburn et al. 2016, Page et al. 2016). Similarly, for feedback received about the lack of diversity among stakeholders, there is a tendency for 
Table 5. Workshop feedback comments illustrating the successes and limitations of the scenario building process. The trade-offs listed here represent a condensed version of those described in Table 2.

\begin{tabular}{ll}
\hline \hline Trade-offs & Illustrative comments \\
\hline $\begin{array}{l}\text { Maintaining relevancy to } \\
\text { stakeholders and specific }\end{array}$ & Evidence of success: \\
decision contexts versus invoking & "Mod, what are we doing?"”
\end{tabular}

more explorative and

transformative thinking

Challenging (and sometimes uncomfortable) nature of envisioning very different and perhaps idiosyncratic futures versus the need to find common areas of concern and not make too many incursions on stakeholders' time
Evidence of process limitations:

"More specifics on how to use this tool in my own organization on a day to day basis. And how this will be used by us in the future?"

"Guessing why change may happen isn't as valuable perhaps as by-in for how to choose it."

Evidence of success:

"Providing a useful structure to beginning a conversation/thinking about the future (versus perhaps being overwhelmed by all the uncertainties)."

"Future scenarios was a new and different way to look at the issue; it made me think differently."

"[learnt] to really think outside the present."

"Like being forced to consider endpoints rather than extrapolation of trends."

"...coming away with a broader spectrum of what the future look like."

"It is not as difficult as I thought - easier and more fun to imagine."

Evidence of process limitations:

“... was tough to wrap your arms around a 50 -year scenario. The 50 years covers many generations and unforeseen changes."

"....still found this hard (appreciating change into the future)"

"[learnt] how hard it is for some people to step outside of their own mind-set even for hypothetical situations."

"[suggest] sharpening group appreciation of the pace of change in the next 50 years - start with a futurist."

"[need to] somehow get people further out of their hopes and aspirations - "utopian' scenarios. Less idyllic."

"No right answers got us uncomfortable."

Balancing not making too many commitments on stakeholders' time against maximizing stakeholder involvement in the process

Engagement with stakeholders versus scientific credibility and the needs of scientists
Evidence of success:

"Overall setup and methods worked really well."

"[liked] space, pace, excellent facilitation."

"Encouraged thoughtful discussion and to hear different perspectives. Good job!"

"Very clean instructions; I like the step-wise building out of our scenarios."

"The scenario building process was as a whole new to me. Well thought out and organized."

Evidence of process limitations:

"Difficult to do scenario planning rapidly."

"[I would have liked] more time to discuss and develop scenarios."

"Exercises were challenging but I was glad that it was acknowledged that these were meant to be difficult."

Evidence of success:

"[I liked] the scenario development process. Asking of visioning/futuring without becoming over-whelmed with the weighting modelling of observing the future. Scenarios: the future made easy.”

Evidence of process limitations:

"Sometimes too wonkey/theoretical (comes with the kind of modeling)."

"... seems like too much of a back of the envelope approach on which to base detailed modeling."

"Nonexpert environmentalists guessing scenarios isn't developing realistic scenarios. How can enviros be predicting forest product demand!"

"Deciding the numbers on the final sheet was difficult. I could see more qualitative focus group type data gathering might capture more of the ideas that could be lost through our discussions that did not get on paper." certain stakeholder groups, such as industry representatives, to remain underrepresented in transdisciplinary research programs (Johnson et al. 2012, Oteros-Rozas et al. 2015, de Vente et al. 2016). One area in which our process did appear to differ and possibly offer an advantage was in avoiding the more strongly negative reactions to scenario processes reported for some of the 23 case studies (Oteros-Rozas et al. 2015; and see also Reed et al. 2013). The fact that stakeholders who directly participated in the codesign process were less likely to question the usefulness of the scenario development outputs is also promising (see also de Vente et al. 2016).

The postworkshop and webinar questionnaires were intended as formative evaluations and thus provide only a partial and imperfect metric of the relative success of the codesigned scenario development process, owing in part to the biases and limitations with self-reported data, and to the fact that the NE-LFP is still ongoing (Chan 2009, Roux et al. 2010). They also address only a single measure of success, stakeholder perspectives on the scenario workshop process and its outputs. Additional evaluations are planned for the NE-LFP with the intention of elucidating a more holistic understanding of the relative benefits that a codesign approach can provide across a broader range of dimensions, including: quality/effectiveness of the process and products, changes in understanding (e.g., increased knowledge, or awareness, skills, or attitude change), and impacts on practice and policy (Walter et al. 2007, Fazey et al. 2014). 
Table 6. Stakeholder feedback solicited during the webinars $(n=26)$.

\begin{tabular}{|c|c|c|c|}
\hline Feedback questions & $\begin{array}{l}\text { Yes } \\
(\%)\end{array}$ & Somewhat (\%) & No $(\%)$ \\
\hline $\begin{array}{l}\text { Do you think the regional driver... } \\
\text {.."Natural Resource Use" effectively encompasses } \\
\text { the related group of state drivers? } \\
\text { ".. Socioeconomic Connectedness" effectively encompasses the related group of state drivers? } \\
\text { Is the resulting matrix relevant to you and your work? } \\
\text { How relevant are these storylines to you and your work? } \\
\text { Example narrative-to-model translation question: } \\
\text { In scenario 1, we envision a growing and urbanizing population with increasing rates of "smart" development. } \\
\text { This means that: } \\
\quad \text { Rates of development increase primarily around major cities in southern New England } \\
\quad \text { Rates of development will increase around major and minor cities throughout New England } \\
\quad \text { Development rates increase everywhere in clusters of new development, but not necessarily tied to } \\
\text { traditional urban areas } \\
\text { Example storyline fleshing out question: } \\
\text { For scenario } 2 \text {, what drives the shift to localism? } \\
\quad \text { A preference for local community living to counter the increasingly virtual environments used for work } \\
\text { and socializing } \\
\text { A shift in social and cultural values toward preferring an eco-friendly, sustainable, low-footprint lifestyle } \\
\text { Other (please specify your ideas below): }\end{array}$ & $\begin{array}{l}64 \\
65 \\
62 \\
69\end{array}$ & $\begin{array}{l}36 \\
26 \\
35 \\
31\end{array}$ & $\begin{array}{l}0 \\
9 \\
4 \\
0\end{array}$ \\
\hline
\end{tabular}

\section{Improving the process of codesign: critical reflections on the New England Landscape Futures Project (NE-LFP) case study}

As noted in the process objectives, our intention in codesigning the scenario development process was to tailor the activities and approach to the stated preferences of stakeholders and scientists. A possible limitation with this approach, not considered at the outset, is the risk of developing a process that largely caters to participants' pre-existing ideas about their needs for long-term orientated land-use policy and planning, missing the opportunity to challenge assumptions about foresight exercises and generate more transformative insights. Our stakeholders, for instance, indicated that one day for scenario development would be all that it would be reasonable to ask people to commit, a design requirement that runs counter to the sufficient time required for scenarios to prompt deeper reflection and exploration (see also Table 2). This risk is particularly relevant when codesigning scenario-based processes, given the disconnect between typical preferences toward pragmatic and time driven outcomes with a concrete focus versus the embracing of uncertainty and openness for exploration and new ideas through which scenarios are most truly successful (Burt and Chermack 2008, Ramírez and Selin 2014, Vervoort et al. 2015, Bowman 2016).

Given that postworkshop feedback included a desire for more time, this raises the question of to what degree a codesign process should only respond to stakeholders' preferences versus actively trying to inform stakeholders about process requirements that may run counter to their initial expectations (such as more time might be needed than the participants may at first think is necessary). Although our initial codesign workshop included presentations and discussion panels with experienced scenario practitioners to inform stakeholders and scientists about the requirements for successful outcomes, an even greater focus on using codesign as a learning opportunity through which to better establish the motivation for scenario analysis may be beneficial.
And because participants directly involved in the codesign process appeared to have a stronger grasp of how scenarios could be eventually applied than those not directly involved, it appears that collaborative design may be particularly useful as a platform through which to establish the utility of foresight knowledge, enhancing its ability to generate actionable science in support of sustainable futures (Page et al. 2016).

A related issue is whether the scope of the scenario codesign process will be limited by the process organizer's knowledge and understanding of scenario methods. First, any methods the project team are not aware of will necessarily not receive adequate consideration. More subtly, the way in which the project organizers perceive and communicate the techniques and tradeoffs to stakeholders will influence the codesign process. This suggests that developing a greater awareness of the wide and everevolving range of methodologies available, particularly outside the standard two-axis/matrix approach that dominates in environmental scenario practice (e.g., Rounsevell and Metzger 2010), may be important in extending the scope of a codesign process. For the NE-LFP, despite our best efforts to draw from literature and consult with experienced scenario practitioners operating in the region, we still felt at times that the design process was limited by our lack of knowledge regarding the different methodologies available and how their drawbacks and advantages would play out for our particular context. Some of this could be corrected by greater efforts to report on and evaluate the benefits of different scenario methods, an area of the environmental scenario literature that remains underdeveloped (Oteros-Rozas et al. 2015).

Other aspects of our codesign process worth reflecting on include the balance of time spent on codesign versus actual implementation. A codesign approach entails additional time commitments from participants that might otherwise have been 
spent on scenario development. The literature on transdisciplinary research suggests that this is time well spent and that participatory processes benefit from a lengthy project scoping and codesign stage as a means to build trust, ownership, and process legitimacy (Kirchhoff et al. 2013, Meadow et al. 2015, Polk 2015, Reyers et al. 2015, Clark et al. 2016, Cockburn et al. 2016, Page et al. 2016). A less straightforward question is what level and type of stakeholder participation in the design process is necessary to ensure success, given the amount of work involved in designing a scenario process when combined with the need to adequately inform stakeholders about scenario practice research. Our approach to navigating this issue was to develop the framework for the process in direct collaboration with stakeholders, while leaving choices about the specific scenario development techniques and materials within this broad process framework to the core research team. The workshop feedback suggests this approach had drawbacks, with details of the process that stakeholders were not directly involved in specifying, such as the process for translating the narratives to semiquantitative outputs, discovered to be problematic upon implementation. The conclusion to draw is not necessarily that the choice to use this approach was incorrect, but rather that by more fully involving stakeholders in this decision process and enhancing their understanding of the reasoning and motivations behind its inclusion, they may have come to view the translation stage as challenging but ultimately worthwhile.

The limitations of the codesign process experienced in our case study suggest that a worthwhile avenue to explore in the future would be a more cyclical approach to scenario exercise codesign, which makes use of multiple iterations of process design and execution (Wilkinson and Eidinow 2008, Vervoort et al. 2014, Sarkki et al. 2015). Codesign processes are integrative in nature and best implemented via an iterative, reflexive cycle (Mauser et al. 2013, Page et al. 2016). Embedding scenario development codesign and implementation into a sustained social learning process would allow participants to learn through experience and application (Lemos and Morehouse 2005, Vervoort et al. 2014, Sarkki et al. 2015). In doing so, it would represent a move away from the use of scenarios as a once only exercise and toward a tool for ongoing adaptive organizational learning (e.g., van der Heijden 1996, Burt and Chermack 2008, Wilkinson and Eidinow 2008, Kok et al. 2011). Current usage suggests that environmental applications may also benefit from giving greater emphasis to the collaborative sense-making aspect of scenario building, rather than the products-based focus that has tended to dominate (Parson 2008, Oteros-Rozas et al. 2015, Ramírez and Wilkinson 2016, Kok et al. 2017).

Finally, any attempt at codesign requires balancing a diversity of needs, preferences, and expectations across different stakeholder groups (Lemos et al. 2014, Clark et al. 2016). Attempting to engage a diverse body of stakeholders within a single process is unlikely to satisfy all participants, and we believe that at least some of the conflicting workshop feedback received (e.g., for longer or shorter processes) reflects this fact. Evolving toward a method that codesigns multiple scenario development processes with individual stakeholder groups would be one approach to overcoming this issue. For the NE-LFP, we did not set out to restrict choices to a single method for scenario development (though this may have been an implicit assumption) and we would have been open to the use of multiple scenario development methods should it have emerged as necessary for balancing competing engagement demands and/or preferences from stakeholders. The codesign of individualized processes would also need to be balanced against the loss of the opportunity to bring together individuals from different sectors for knowledge exchange and partnership building. The greater resources and time commitments required to tailor the process to individual stakeholder groups would also place additional demands on what are likely already limited resources and capacity, an ongoing challenge in the mainstreaming of knowledge coproduction systems (e.g., Cowling et al. 2008, Kirchhoff et al. 2013, Meadow et al. 2015, Polk 2015). As we noted earlier, more targeted stakeholder-specific engagement processes are in planning for the application stage of the NE-LFP.

\section{CONCLUSION}

The outcomes from the NE-LFP application suggest that we may be able to increase the odds of fulfilling the transformative potential of participatory scenario planning activities by engaging in a collaborative design process that considers the needs of both researchers and stakeholders from the outset and throughout the process. By actively involving the stakeholders in the design of the scenario development process, we were able to define clear objectives for scenario development with stakeholders and give adequate consideration to how participants could be empowered through the scenario development activities. In the process of walking through a codesign process, we have highlighted the major trade-offs that ought to be considered in the design process, and we have shown how giving adequate consideration to design can have a substantial impact on the resulting scenario development process. Further, our experiences suggest that involving stakeholders in process codesign can act as a shared learning experience with the potential to not only inform the tailoring of the process to the needs of diverse user groups, but to also facilitate a greater understanding among stakeholders about the role for scenario development in generating relevant knowledge to inform land-use planning and decision making. Given the impact that the methods used have on process outcomes, establishing a broader community of practice that aims to share methods, challenges, and outcomes in a comparative way will be important next step for advancing participatory scenario practice.

Responses to this article can be read online at: http://www.ecologyandsociety.org/issues/responses. $\mathrm{php} / 9386$

\footnotetext{
Acknowledgments:

This research was supported in part by the National Science Foundation Harvard Forest Long Term Ecological Research Program (Grant No. NSF-DEB 12-37491) and the Scenarios Society and Solutions Research Coordination Network (Grant No. NSF-DEB-13-38809). We thank Josh Plisinski and David Buckley Borden for their assistance in preparing the figures. We are grateful to the many participating stakeholders for their engagement in the scenario process. Specifically, we thank Charlie Hancock, Nancy
} 
Patch and the Cold Hollow to Canada Regional Conservation Partnership, Jack Buckey and the Massachusetts Division of Fisheries and Wildlife, LandVest, the New England Forestry Foundation, Martha Sheils and the New England Environmental Finance Centre, Highstead, the Global Institute of Sustainable Forestry at the Yale School of Forestry and Environmental Studies, Rupert Friday and the Rhode Island Land Trust Council, Chris Riely and the Rhode Island Woodland Partnership, the Rhode Island Natural Resources Conservation Service, Sarah Garlick and Hubbard Brook Research Foundation, Northern Forest Center, Dartmouth College, and the University of New Hampshire.

\section{LITERATURE CITED}

Alcamo, J. 2008b. Environmental futures: the practice of environmental scenario analysis. Elsevier, Amsterdam, The Netherlands.

Alcamo, J. 2008c. The SAS approach: combining qualitative and quantitative knowledge in environmental scenarios. Pages 123-150 in J. Alcamo, editor. Environmental futures: the practice of environmental scenario analysis. Elsevier, Amsterdam, The Netherlands.

Alcamo, J. 2008a. Towards guidelines for environmental scenario analysis. Pages 13-35 in J. Alcamo, editor. Environmental futures: the practice of environmental scenario analysis. Elsevier, Amsterdam, The Netherlands.

Amer, M., T. U. Daim, and A. Jetter. 2013. A review of scenario planning. Futures 46:23-40. http://dx.doi.org/10.1016/j. futures.2012.10.003

Bennett, E. M. 2017. Research frontiers in ecosystem service science. Ecosystems 20(1):31-37. http://dx.doi.org/10.1007/ s10021-016-0049-0

Berkhout, F., J. Hertin, and A. Jordan. 2002. Socio-economic futures in climate change impact assessment: using scenarios as 'learning machines'. Global Environmental Change 12(2):83-95. http://dx.doi.org/10.1016/S0959-3780(02)00006-7

Biggs, R., C. Raudsepp-Hearne, C. Atkinson-Palombo, E. Bohensky, E. Boyd, G. Cundill, H. Fox, S. Ingram, K. Kok, S. Spehar, M. Tengö, D. Timmer, and M. Zurek. 2007. Linking futures across scales: a dialog on multiscale scenarios. Ecology and Society 12(1):17. http://dx.doi.org/10.5751/ES-02051-120117

Binder, C. R., I. Absenger-Helmli, and T. Schilling. 2015. The reality of transdisciplinarity: a framework-based self-reflection from science and practice leaders. Sustainability Science 10 (4):545-562. http://dx.doi.org/10.1007/s11625-015-0328-2

Bishop, P., A. Hines, and T. Collins. 2007. The current state of scenario development: an overview of techniques. Foresight 9:5-25. http://dx.doi.org/10.1108/14636680710727516

Blumstein, M., and J. R. Thompson. 2015. Land-use impacts on the quantity and configuration of ecosystem service provisioning in Massachusetts, USA. Journal of Applied Ecology 52 (4):1009-1019. http://dx.doi.org/10.1111/1365-2664.12444

Bohensky, E., J. R. A. Butler, R. Costanza, I. Bohnet, A. Delisle, K. Fabricius, M. Gooch, I. Kubiszewski, G. Lukacs, P. Pert, and E. Wolanski. 2011. Future makers or future takers? A scenario analysis of climate change and the Great Barrier Reef. Global Environmental Change 21(3):876-893. http://dx.doi.org/10.1016/ j.gloenvcha.2011.03.009

Booth, E. G., J. Qiu, S. R. Carpenter, J. Schatz, X. Chen, C. J. Kucharik, S. P. Loheide, II, M. M. Motew, J. M. Seifert, and M. G. Turner. 2016. From qualitative to quantitative environmental scenarios: translating storylines into biophysical modeling inputs at the watershed scale. Environmental Modelling and Software 85:80-97. http://dx.doi.org/10.1016/j.envsoft.2016.08.008

Börjeson, L., M. Höjer, K.-H. Dreborg, T. Ekvall, and G. Finnveden. 2006. Scenario types and techniques: towards a user's guide. Futures 38(7):723-739. http://dx.doi.org/10.1016/j. futures.2005.12.002

Bowman, G. 2016. The practice of scenario planning: an analysis of inter-and intra-organizational strategizing. British Journal of Management 27(1):77-96. http://dx.doi.org/10.1111/1467-8551.12098

Bowman, G., R. B. MacKay, S. Masrani, and P. McKiernan. 2013. Storytelling and the scenario process: understanding success and failure. Technological Forecasting and Social Change 80:735-748. http://dx.doi.org/10.1016/j.techfore.2012.04.009

Bradfield, R., G. Wright, G. Burt, G. Cairns, and K. Van Der Heijden. 2005. The origins and evolution of scenario techniques in long range business planning. Futures 37(8):795-812. http://dx. doi.org/10.1016/j.futures.2005.01.003

Bradfield, R. M. 2008. Cognitive barriers in the scenario development process. Advances in Developing Human Resources 10(2):198-215. http://dx.doi.org/10.1177/1523422307313320

Bryson, J. M. 2004. What to do when stakeholders matter: stakeholder identification and analysis techniques. Public Management Review 6(1):21-53. http://dx.doi.org/10.1080/1471$\underline{9030410001675722}$

Bryson, S., M. Grime, A. Murthy, and G. Wright. 2016. Behavioral issues in the practical application of scenario thinking: cognitive biases, effective group facilitation and overcoming business-as-usual thinking. Pages 195-212 in M. Kunc, J. Malpass, and L. White, editors. Behavioral operational research: theory, methodology and practice. Palgrave Macmillan, London, UK. http://dx.doi.org/10.1057/978-1-137-53551-1_10

Burt, G., and T. J. Chermack. 2008. Learning with scenarios: summary and critical issues. Advances in Developing Human Resources 10(2):285-295. http://dx.doi.org/10.1177/1523422307313334

Butler, B., J. H. Hewes, B. J. Dickinson, K. Andrejczyk, S. M. Butler, and M. Markowski-Lindsay. 2016. USDA Forest Service National Woodland Owner Survey: national, regional, and state statistics for family forest and woodland ownerships with 10+ acres, 2011-2013. Forest Service Research Bulletin NRS-99. U.S. Department of Agriculture, Forest Service, Northern Research Station, Newtown Square, Pennsylvania, USA. [online] URL: https://www.fs.fed.us/nrs/pubs/rb/rb_nrs99.pdf

Cairns, G., G. Wright, and P. Fairbrother. 2016. Promoting articulated action from diverse stakeholders in response to public policy scenarios: a case analysis of the use of 'scenario improvisation' method. Technological Forecasting and Social Change 103:97-108. http://dx.doi.org/10.1016/j.techfore.2015.10.009 
Capitani, C., K. Mukama, B. Mbilinyi, I. Malugu, P. K. T. Munishi, N. D. Burgess, P. J. Platts, S. M. Sallu, and R. Marchant. 2016. From local scenarios to national maps: a participatory framework for envisioning the future of Tanzania. Ecology and Society 21(3):4. http://dx.doi.org/10.5751/es-08565-210304

Carpenter, S. R., E. G. Booth, S. Gillon, C. J. Kucharik, S. Loheide, A. S. Mase, M. Motew, J. Qiu, A. R. Rissman, J. Seifert, E. Soylu, M. Turner, and C. B. Wardropper. 2015. Plausible futures of a social-ecological system: Yahara watershed, Wisconsin, USA. Ecology and Society 20(2):10. http://dx.doi. org/10.5751/es-07433-200210

Cash, D. W., W. C. Clark, F. Alcock, N. M. Dickson, N. Eckley, D. H. Guston, J. Jäger, and R. B. Mitchell. 2003. Knowledge systems for sustainable development. Proceedings of the National Academy of Sciences 100(14):8086-8091. http://dx.doi.org/10.1073/ pnas. 1231332100

Chan, D. 2009. So why ask me? Are self-report data really that bad? Pages 309-336 in C. E. Lance and R. J. Vandenberg, editors. Statistical and methodological myths and urban legends: doctrine, verity and fable in the organizational and social sciences. Taylor and Francis, New York, New York, USA.

Chaudhury, M., J. Vervoort, P. Kristjanson, P. Ericksen, and A. Ainslie. 2013. Participatory scenarios as a tool to link science and policy on food security under climate change in East Africa. Regional Environmental Change 13(2):389-398. http://dx.doi. org/10.1007/s10113-012-0350-1

Clark, W. C., L. van Kerkhoff, L. Lebel, and G. C. Gallopin. 2016. Crafting usable knowledge for sustainable development. Proceedings of the National Academy of Sciences 113 (17):4570-4578. http://dx.doi.org/10.1073/pnas.1601266113

Cockburn, J., M. Rouget, R. Slotow, D. Roberts, R. Boon, E. Douwes, S. O'Donoghue, C. T. Downs, S. Mukherjee, W. Musakwa, O. Mutanga, T. Mwabvu, J. Odindi, A. Odindo, Ş. Procheş, S. Ramdhani, J. Ray-Mukherjee, Sershen, M. C. Schoeman, A. J. Smit, E. Wale, and S. Willows-Munro. 2016. How to build science-action partnerships for local land-use planning and management: lessons from Durban, South Africa. Ecology and Society 21(1):28. http://dx.doi.org/10.5751/es-08109-210128

Corbin, J., and A. Strauss. 2014. Basics of qualitative research: techniques and procedures for developing grounded theory. Sage, Thousand Oaks, California, USA.

Cowling, R. M., B. Egoh, A. T. Knight, P. J. O’Farrell, B. Reyers, M. Rouget, D. J. Roux, A. Welz, and A. Wilhelm-Rechman. 2008. An operational model for mainstreaming ecosystem services for implementation. Proceedings of the National Academy of Sciences 105(28):9483-9488. http://dx.doi.org/10.1073/pnas.0706559105

Creswell, J. W., and V. L. Plano Clark. 2007. Designing and conducting mixed methods research. Sage, Thousand Oaks, California, USA.

Davis, G. 2002. Scenarios as a tool for the 21st century. Probing the future conference. Strathclyde University, Glasgow, Scotland. [online] URL: https://www.pik-potsdam.de/avec/peyresq2005/ talks/0921/leemans/literature/davis how does shell do scenarios. pd https://www.pik-potsdam.de/avec/peyresq2005/talks/0921/leemans/ literature/davis_how_does_shell_do_scenarios.pdf
Daw, T. M., S. Coulthard, W. W. L. Cheung, K. Brown, C. Abunge, D. Galafassi, G. D. Peterson, T. R. McClanahan, J. O. Omukoto, and L. Munyi. 2015. Evaluating taboo trade-offs in ecosystems services and human well-being. Proceedings of the National Academy of Sciences 112(22):6949-6954. http://dx.doi.org/10.1073/ pnas. 1414900112

de Vente, J., M. S. Reed, L. C. Stringer, S. Valente, and J. Newig. 2016. How does the context and design of participatory decision making processes affect their outcomes? Evidence from sustainable land management in global drylands. Ecology and Society 21(2):24. http://dx.doi.org/10.5751/es-08053-210224

Evely, A. C., M. Pinard, M. S. Reed, and I. Fazey. 2011. High levels of participation in conservation projects enhance learning. Conservation Letters 4(2):116-126. http://dx.doi.org/10.1111/ j.1755-263x.2010.00152.x

Fazey, I., L. Bunse, J. Msika, M. Pinke, K. Preedy, A. C. Evely, E. Lambert, E. Hastings, S. Morris, and M. S. Reed. 2014. Evaluating knowledge exchange in interdisciplinary and multistakeholder research. Global Environmental Change 25:204-220. http://dx.doi.org/10.1016/j.gloenvcha.2013.12.012

Foster, D. R. 2013. New science, synthesis, scholarship, and strategic vision for society. Harvard forest lter V 2012-2018. Harvard Forest, Harvard, University, Cambridge, Massachusetts, USA. [online] URL: http://harvardforest.fas.harvard.edu/sites/ harvardforest.fas.harvard.edu/files/publications/pdfs/LTERV-2012proposal.pdf

Foster, D. R., K. Fallon Lambert, and J. R. Thompson. 2014. Integrating land-use scenarios, ecosystem services, and linkages to society. National Science Foundation, Harvard Forest, Harvard University, Cambridge, Massachusetts, USA.

Freeth, R., and S. Drimie. 2016. Participatory scenario planning: from scenario 'stakeholders' to scenario 'owners'. Environment: Science and Policy for Sustainable Development 58(4):32-43. http://dx.doi.org/10.1080/00139157.2016.1186441

Gallopín, G. C., and F. Rijsberman. 2000. Three global water scenarios. International Journal of Water 1(1):16-40. http://dx.doi. org/10.1504/ijw.2000.002055

Godemann, J. 2008. Knowledge integration: a key challenge for transdisciplinary cooperation. Environmental Education Research 14(6):625-641. http://dx.doi.org/10.1080/13504620802469188

Henrichs, T., M. Zurek, B. Eickhout, K. Kok, C. RaudseppHearne, T. Ribeiro, D. van Vuuren, and A. Volkery. 2010. Scenario development and analysis for forward-looking ecosystem assessments. Pages 151-220 in N. Ash, H. Blanco, K. Garcia, T. Tomich, B. Vira, M. Zurek, and C. Brown, editors. Ecosystems and human well-being: a manual for assessment practitioners. Island, Washington, D.C., USA.

Iwaniec, D. M., G. S. Metson, and D. Cordell. 2016. PFUTURES: towards urban food and water security through collaborative design and impact. Current Opinion in Environmental Sustainability 20:1-7. http://dx.doi.org/10.1016/j. cosust.2016.03.001

Johnson, K. A., G. Dana, N. R. Jordan, K. J. Draeger, A. Kapuscinski, L. K. Schmitt Olabisi, and P. B. Reich. 2012. Using 
participatory scenarios to stimulate social learning for collaborative sustainable development. Ecology and Society 17 (2):9. http://dx.doi.org/10.5751/es-04780-170209

Kirchhoff, C. J., M. Carmen Lemos, and S. Dessai. 2013. Actionable knowledge for environmental decision making: broadening the usability of climate science. Annual Review of Environment and Resources 38:393-414. http://dx.doi.org/10.1146/ annurev-environ-022112-112828

Kok, K., M. van Vliet, I. Bärlund, A. Dubel, and J. Sendzimir. 2011. Combining participative backcasting and exploratory scenario development: experiences from the SCENES project. Technological Forecasting and Social Change 78(5):835-851. http://dx.doi.org/10.1016/j.techfore.2011.01.004

Kok, M. T. J., K. Kok, G. D. Peterson, R. Hill, J. Agard, and S. R. Carpenter. 2017. Biodiversity and ecosystem services require IPBES to take novel approach to scenarios. Sustainability Science 12(1):177-181. http://dx.doi.org/10.1007/s11625-016-0354-8

Kunseler, E.-M., W. Tuinstra, E. Vasileiadou, and A. C. Petersen. 2015. The reflective futures practitioner: balancing salience, credibility and legitimacy in generating foresight knowledge with stakeholders. Futures 66:1-12. $\underline{\text { http://dx.doi.org/10.1016/j. }}$ futures.2014.10.006

Lang, D. J., A. Wiek, M. Bergmann, M. Stauffacher, P. Martens, P. Moll, M. Swilling, and C. J. Thomas. 2012. Transdisciplinary research in sustainability science: practice, principles, and challenges. Sustainability Science 7(1):25-43. http://dx.doi. org/10.1007/s11625-011-0149-X

Lemos, M. C., C. J. Kirchhoff, S. E. Kalafatis, D. Scavia, and R. B. Rood. 2014. Moving climate information off the shelf: boundary chains and the role of RISAs as adaptive organizations. Weather, Climate, and Society 6(2):273-285. http://dx.doi. org/10.1175/wcas-d-13-00044.1

Lemos, M. C., and B. J. Morehouse. 2005. The co-production of science and policy in integrated climate assessments. Global Environmental Change 15(1):57-68. http://dx.doi.org/10.1016/j. gloenvcha.2004.09.004

Lord, S., A. Helfgott, and J. M. Vervoort. 2016. Choosing diverse sets of plausible scenarios in multidimensional exploratory futures techniques. Futures 77:11-27. http://dx.doi.org/10.1016/j. futures.2015.12.003

Mallampalli, V. R., G. Mavrommati, J. Thompson, M. Duveneck, S. Meyer, A. Ligmann-Zielinska, C. G. Druschke, K. Hychka, M. A. Kenney, K. Kok, and M. E. Borsuk. 2016. Methods for translating narrative scenarios into quantitative assessments of land use change. Environmental Modelling and Software 82:7-20. http://dx.doi.org/10.1016/j.envsoft.2016.04.011

Mauser, W., G. Klepper, M. Rice, B. S. Schmalzbauer, H. Hackmann, R. Leemans, and H. Moore. 2013. Transdisciplinary global change research: the co-creation of knowledge for sustainability. Current Opinion in Environmental Sustainability 5 (3):420-431. http://dx.doi.org/10.1016/j.cosust.2013.07.001

Meadow, A. M., D. B. Ferguson, Z. Guido, A. Horangic, G. Owen, and T. Wall. 2015. Moving toward the deliberate coproduction of climate science knowledge. Weather, Climate, and Society 7(2):179-191. $\quad$ http://dx.doi.org/10.1175/wcasd-14-00050.1

Mitchell, M., M. Lockwood, S. A. Moore, and S. Clement. 2016. Building systems-based scenario narratives for novel biodiversity futures in an agricultural landscape. Landscape and Urban Planning 145:45-56. http://dx.doi.org/10.1016/j.landurbplan.2015.09.003

Newig, J., and O. Fritsch. 2009. Environmental governance: participatory, multi-level and effective? Environmental Policy and Governance 19(3):197-214. http://dx.doi.org/10.1002/eet.509

Olofsson, P., C. E. Holden, E. L. Bullock, and C. E. Woodcock. 2016. Time series analysis of satellite data reveals continuous deforestation of New England since the 1980s. Environmental Research Letters 11(6):064002. http://dx.doi.org/10.1088/1748-9$\underline{326 / 11 / 6 / 064002}$

Oteros-Rozas, E., B. Martín-López, T. Daw, E. L. Bohensky, J. Butler, R. Hill, J. Martin-Ortega, A. Quinlan, F. Ravera, I. RuizMallén, M. Thyresson, J. Mistry, I. Palomo, G. D. Peterson, T. Plieninger, K. A. Waylen, D. Beach, I. C. Bohnet, M. Hamann, J. Hanspach, K. Hubacek, S. Lavorel, and S. Vilardy. 2015. Participatory scenario planning in place-based social-ecological research: insights and experiences from 23 case studies. Ecology and Society 20(4):32. http://dx.doi.org/10.5751/ES-07985-200432

Page, G. G., R. M. Wise, L. Lindenfeld, P. Moug, A. Hodgson, C. Wyborn, and I. Fazey. 2016. Co-designing transformation research: lessons learned from research on deliberate practices for transformation. Current Opinion in Environmental Sustainability 20:86-92. http://dx.doi.org/10.1016/j.cosust.2016.09.001

Pahl-Wostl, C. 2008. Participation in building environmental scenarios. Pages 105-122 in J. Alcamo, editor. Environmental futures: the practice of environmental scenario analysis. Elsevier, Amsterdam, The Netherlands.

Parker, A. M., S. V. Srinivasan, R. J. Lempert, and S. H. Berry. 2015. Evaluating simulation-derived scenarios for effective decision support. Technological Forecasting and Social Change 91:64-77. http://dx.doi.org/10.1016/j.techfore.2014.01.010

Parson, E. A. 2008. Useful global-change scenarios: current issues and challenges. Environmental Research Letters 3(4):045016. http://dx.doi.org/10.1088/1748-9326/3/4/045016

Peterson, G. D., G. S. Cumming, and S. R. Carpenter. 2003. Scenario planning: a tool for conservation in an uncertain world. Conservation Biology 17(2):358-366. http://dx.doi.org/10.1046/ j.1523-1739.2003.01491.X

Polk, M. 2015. Transdisciplinary co-production: designing and testing a transdisciplinary research framework for societal problem solving. Futures 65:110-122. http://dx.doi.org/10.1016/j. futures.2014.11.001

Posner, S. M., E. McKenzie, and T. H. Ricketts. 2016. Policy impacts of ecosystem services knowledge. Proceedings of the National Academy of Sciences 113(7):1760-1765. http://dx.doi. org/10.1073/pnas.1502452113

Ramírez, R., and C. Selin. 2014. Plausibility and probability in scenario planning. Foresight 16(1):54-74. http://dx.doi.org/10.1108/ $\underline{\text { fs-08-2012-0061 }}$ 
Ramírez, R., and A. Wilkinson. 2016. Strategic reframing: the Oxford scenario planning approach. Oxford University Press, Oxford, UK. http://dx.doi.org/10.1093/acprof:oso/9780198745693.001.0001

Reed, M. S., J. Kenter, A. Bonn, K. Broad, T. P. Burt, I. R. Fazey, E. D. G. Fraser, K. Hubacek, D. Nainggolan, C. H. Quinn, L. C. Stringer, and F. Ravera. 2013. Participatory scenario development for environmental management: a methodological framework illustrated with experience from the UK uplands. Journal of Environmental Management 128:345-362. http://dx.doi.org/10.1016/ j.jenvman.2013.05.016

Reyers, B., J. L. Nel, P. J. O'Farrell, N. Sitas, and D. C. Nel. 2015. Navigating complexity through knowledge coproduction: mainstreaming ecosystem services into disaster risk reduction. Proceedings of the National Academy of Sciences 112 (24):7362-7368. http://dx.doi.org/10.1073/pnas.1414374112

Rickards, L., J. Wiseman, T. Edwards, and C. Biggs. 2014. The problem of fit: scenario planning and climate change adaptation in the public sector. Environment and Planning C: Government and Policy 32(4):641-662. http://dx.doi.org/10.1068/c12106

Rothman, D. S. 2008. A survey of environmental scenarios. Pages 37-65 in J. Alcamo, editor. Environmental futures: the practice of environmental scenario analysis. Elsevier, Amsterdam, The Netherlands.

Rounsevell, M. D. A., and M. J. Metzger. 2010. Developing qualitative scenario storylines for environmental change assessment. Wiley Interdisciplinary Reviews: Climate Change 1 (4):606-619. http://dx.doi.org/10.1002/wcc.63

Rounsevell, M. D. A., B. Pedroli, K.-H. Erb, M. Gramberger, A. G. Busck, H. Haberl, S. Kristensen, T. Kuemmerle, S. Lavorel, M. Lindner, H. Lotze-Campen, M. J. Metzger, D. Murray-Rust, A. Popp, M. Pérez-Soba, A. Reenberg, A. Vadineanu, P. H. Verburg, and B. Wolfslehner. 2012. Challenges for land system science. Land Use Policy 29(4):899-910. http://dx.doi.org/10.1016/ j.landusepol.2012.01.007

Roux, D. J., R. J. Stirzaker, C. M. Breen, E. C. Lefroy, and H. P. Cresswell. 2010. Framework for participative reflection on the accomplishment of transdisciplinary research programs. Environmental Science and Policy 13(8):733-741. http://dx.doi. org/10.1016/j.envsci.2010.08.002

Sarkki, S., R. Tinch, J. Niemelä, U. Heink, K. Waylen, J. Timaeus, J. Young, A. Watt, C. Neßhöver, and S. van den Hove. 2015. Adding 'iterativity' to the credibility, relevance, legitimacy: a novel scheme to highlight dynamic aspects of science-policy interfaces. Environmental Science and Policy 54:505-512. http://dx.doi. org/10.1016/j.envsci.2015.02.016

Schoemaker, P. J. 1998. Twenty common pitfalls in scenario planning. Pages 422-431 in L. Fahey and R. M. Randall, editors. Learning from the future: competitive foresight scenarios. John Wiley and Sons, New York, New York, USA.

Schwarz, P. 1991. The art of the long view: planning for the future in an uncertain world. Doubleday, New York, New York, USA.

Schwartz, P., and J. Ogilvy. 1998. Plotting your scenarios. Pages 57-80 in L. Fahey and R. M. Randall, editors. Learning from the future: competitive foresight scenarios. John Wiley and Sons, New York, New York, USA.

Seppelt, R., C. F. Dormann, F. V. Eppink, S. Lautenbach, and S. Schmidt. 2011. A quantitative review of ecosystem service studies: approaches, shortcomings and the road ahead. Journal of Applied Ecology 48(3):630-636. http://dx.doi.org/10.1111/j.1365-2664.2010.01952. $\underline{\mathrm{X}}$

Thompson, J. R., K. F. Lambert, D. R. Foster, E. N. Broadbent, M. Blumstein, A. M. A. Zambrano, and Y. Fan. 2016. Four landuse scenarios and their consequences for forest ecosystems and services they provide. Ecosphere 7(10):e01469. http://dx.doi. org/10.1002/ecs 2.1469

Thompson, J. R., A. Wiek, F. J. Swanson, S. R. Carpenter, N. Fresco, T. Hollingsworth, T. A. Spies, and D. R. Foster. 2012. Scenario studies as a synthetic and integrative research activity for long-term ecological research. BioScience 62(4):367-376. http://dx.doi.org/10.1525/bio.2012.62.4.8

Van Berkel, D. B., and P. H. Verburg. 2012. Combining exploratory scenarios and participatory backcasting: using an agent-based model in participatory policy design for a multifunctional landscape. Landscape Ecology 27(5):641-658. http:// dx.doi.org/10.1007/s10980-012-9730-7

van der Heijden, K. 1996. Scenarios: the art of strategic conversation. John Wiley and Sons, Chichester, UK.

van Notten, P. W. F., J. Rotmans, M. B. A. van Asselt, and D. S. Rothman. 2003. An updated scenario typology. Futures 35 (5):423-443. http://dx.doi.org/10.1016/s0016-3287(02)00090-3

van Notten, P. W. F., A. M. Sleegers, and M. B. A. van Asselt. 2005. The future shocks: on discontinuity and scenario development. Technological Forecasting and Social Change 72 (2):175-194. http://dx.doi.org/10.1016/j.techfore.2003.12.003

van Vliet, M., K. Kok, A. Veldkamp, and S. Sarkki. 2012. Structure in creativity: an exploratory study to analyse the effects of structuring tools on scenario workshop results. Futures 44 (8):746-760. http://dx.doi.org/10.1016/j.futures.2012.05.002

Vervoort, J. M., R. Bendor, A. Kelliher, O. Strik, and A. E. R. Helfgott. 2015. Scenarios and the art of worldmaking. Futures 74:62-70. http://dx.doi.org/10.1016/j.futures.2015.08.009

Vervoort, J. M., P. K. Thornton, P. Kristjanson, W. Förch, P. J. Ericksen, K. Kok, J. S. I. Ingram, M. Herrero, A. Palazzo, A. E. S. Helfgott, A. Wilkinson, P. HavlÃk, D. Mason-D'Croz, and C. Jost. 2014. Challenges to scenario-guided adaptive action on food security under climate change. Global Environmental Change 28:383-394. http://dx.doi.org/10.1016/j.gloenvcha.2014.03.001

Volkery, A., and T. Ribeiro. 2009. Scenario planning in public policy: understanding use, impacts and the role of institutional context factors. Technological Forecasting and Social Change 76:1198-1207. http://dx.doi.org/10.1016/j.techfore.2009.07.009

Volkery, A., T. Ribeiro, T. Henrichs, and Y. Hoogeveen. 2008. Your vision or my model? Lessons from participatory land use scenario development on a European scale. Systemic Practice and Action Research 21(6):459-477. http://dx.doi.org/10.1007/ $\underline{\text { s11213-008-9104-x }}$ 
Wack, P. 1985. Scenarios: uncharted waters ahead. Harvard Business Review September 1985. [online] URL: https://hbr. org/1985/09/scenarios-uncharted-waters-ahead

Walter, A. I., S. Helgenberger, A. Wiek, and R. W. Scholz. 2007. Measuring societal effects of transdisciplinary research projects: design and application of an evaluation method. Evaluation and Program Planning 30(4):325-338. http://dx.doi.org/10.1016/j. evalprogplan.2007.08.002

Wilkinson, A. 2009. Scenarios practices: in search of theory. Journal of Futures Studies 13(3):107-114.

Wilkinson, A., and E. Eidinow. 2008. Evolving practices in environmental scenarios: a new scenario typology. Environmental Research Letters 3(4):045017. http://dx.doi.org/10.1088/1748-93$\underline{26 / 3 / 4 / 045017}$

Wilkinson, A., R. Kupers, and D. Mangalagiu. 2013. How plausibility-based scenario practices are grappling with complexity to appreciate and address 21 st century challenges. Technological Forecasting and Social Change 80:699-710. http:// dx.doi.org/10.1016/j.techfore.2012.10.031

Wollenberg, E., D. Edmunds, and L. Buck. 2000. Using scenarios to make decisions about the future: anticipatory learning for the adaptive co-management of community forests. Landscape and Urban Planning 47(1):65-77. http://dx.doi.org/10.1016/s0169-2046 (99)00071-7

Wright, G., R. Bradfield, and G. Cairns. 2013. Does the intuitive logics method - and its recent enhancements - produce "effective" scenarios? Technological Forecasting and Social Change 80:631-642. http://dx.doi.org/10.1016/j.techfore.2012.09.003

Zurek, M. B., and T. Henrichs. 2007. Linking scenarios across geographical scales in international environmental assessments. Technological Forecasting and Social Change 74(8):1282-1295. http://dx.doi.org/10.1016/j.techfore.2006.11.005 


\section{Appendix 1. $S^{3} \mathrm{RCN}$ process}

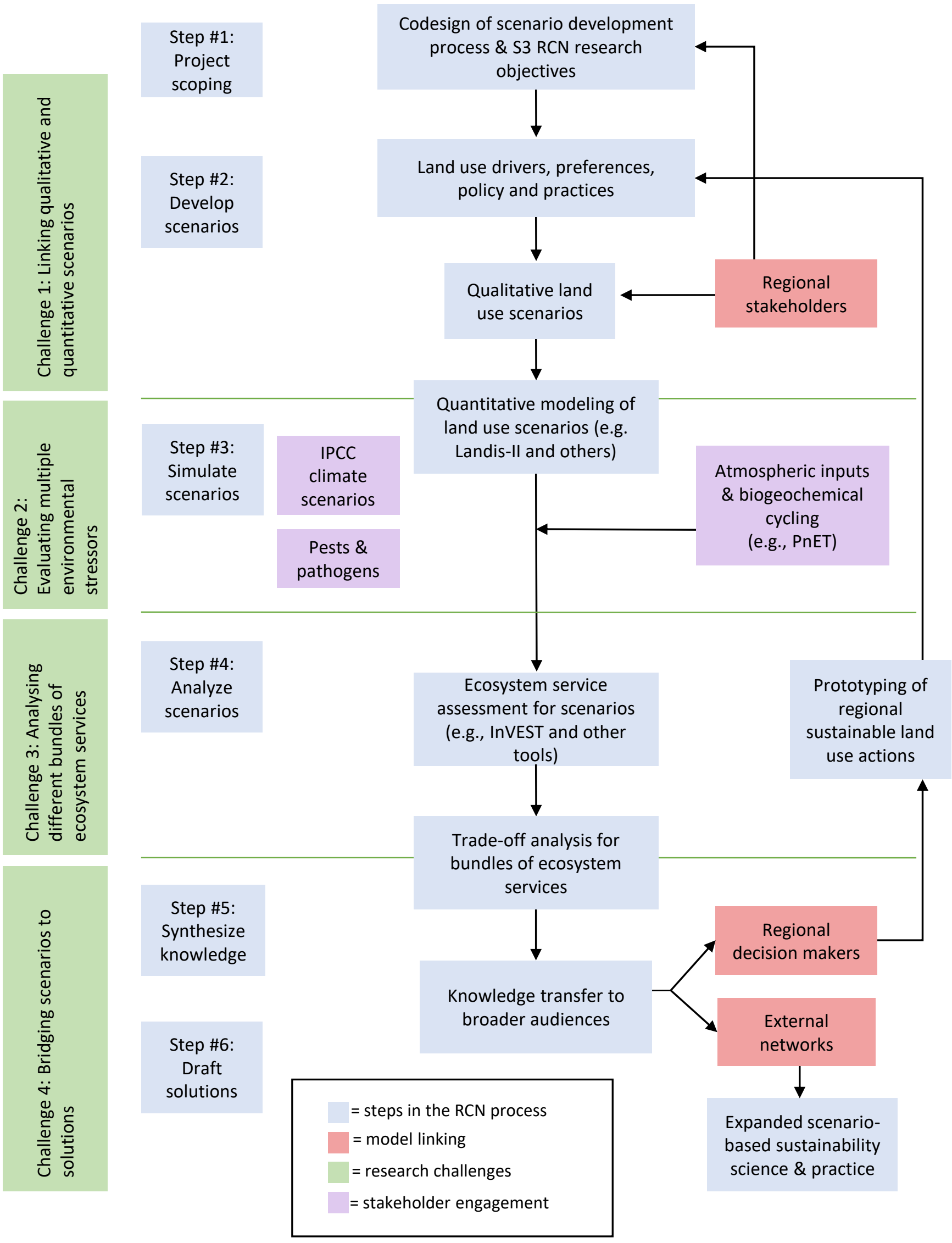




\section{New England Landscape Futures Project Scenarios}

\section{Outcomes of 6 State Scenario Building Workshops}

The Scenarios, Services and Society Research Coordination Network

$12 / 30 / 2015$

Report prepared by Katie Theoharides 


\section{$\underline{\text { Summary }}$}

From September to November 2015 over 120 individuals from across New England participated in six scenario building workshops through the New England Landscape Futures Project. Hosted by the Scenarios, Services and Society Research Coordination Network and partners in each New England state, the workshops led participants familiar with the region through a series of steps to develop four possible but divergent scenarios. Participants represented a variety of sectors including conservation, forestry, state and local resource agencies, academia, community planning, development, real estate, recreation, tourism, and economic development. These workshops are part of a process to help stakeholders and scientists explore the consequences of possible future landscape changes for people and nature, and to support the development of more robust management actions, policies and plans to deal with a range of future conditions.

The approach to scenario building used in these workshops was based on the Global Business Network scenario building method that employs a 2X2 matrix to help structure the scenario narratives, as well as significant input from stakeholders involved in the Scenario to Solutions workshop in the fall of 2014. The process was designed to most efficiently use stakeholders' time while allowing participants to work collaboratively in small groups to develop 4 possible scenarios to compare to recent trends over the next 50 years. The steps in the process balanced creativity with more analytic thinking: from imagining the landscape 50 years into the future from a favorite mountaintop we moved to identifying important drivers of landscape change in each state, ranking and organizing these drivers based on uncertainty and impact, creating and selecting a scenario matrix, and finally, to inhabiting one of the resulting scenarios by imagining what that future might look like and specifically describing the consequences of that scenario in terms of forest conversion, agriculture, timber harvest, and conservation. We assumed that climate change was occurring in each scenario.

This report summarizes the workshop outcomes, including the scenario matrix, bulleted descriptions of the 4 scenarios built by participants in each state, and the consequences of these scenarios for future land cover. The state-level outputs captured here are currently being summarized and collapsed into four scenarios for the entire New England landscape. Scientists in the S3 RCN are now working to model the different scenarios and to quantify the impact of these scenarios on ecosystem services. We will check in again with workshop participants to explain the simulation process and to solicit feedback on the translation approach. Working with partners, we will then apply the results to conservation and land use challenges by supporting strategic conservation and climate adaptation planning, policy development, fundraising, public outreach campaigns, and other efforts. 


\section{Vermont Scenario Workshop Summary}

September 25, 2015

Vermont Technical College, Randolph, Vermont

Strong government with proactive planning that is in favor of working lands

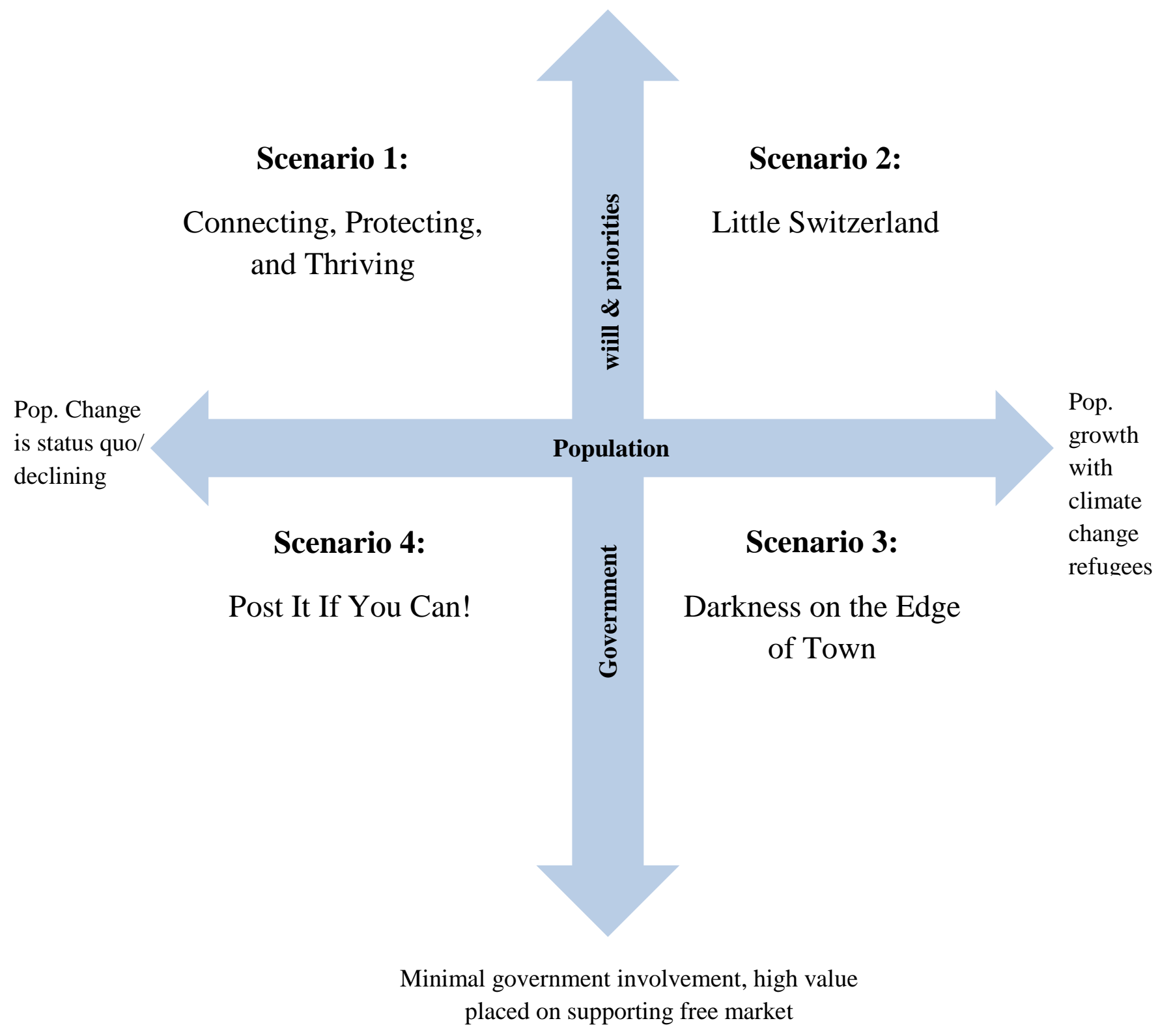

Fig. A2.1. Vermont scenario matrix 


\section{Scenario 1. Connecting, Protecting, and Thriving (CPT)}

Drivers: strong government with proactive planning that is in favor of working lands and population is status quo/declining

\section{Storyline:}

- Forest cover (75\%); intact forest blocks with connectivity; forested riparian corridors; maintained ecological integrity and resiliency

- Rebuild state budgets via capitalizing on modern economy (modern communications and transportation)

- Encourage low-impact businesses including incentives towards working lands enterprises (WLEB); local needs supported by local production (local wood for local good); VT is a leader in export of value-added products

- Fond of permanent protection of ecologically sensitive lands to create a network of working lands and forest reserves

- Fund pre-disaster mitigation; incentivize the protection of flood plains; less agriculture $n$ river valleys, more forested floodplains; fewer dams

- More public resources for local planning efforts

- Government inventory of undeveloped land to connect to diversified ag and forestry

- Energy policy incentives, home-based energy systems; technology improvements preclude the need for industrial scale projects

- Education regarding buying local

- Increase in public values around the value of natural resources and the natural resources economy; traditional uses such as logging, hunting, fishing, etc., are valued and continue to be an important part of the economy

- School curriculums include significant time outside interacting with nature

- More restrictive guidelines for energy siting

- Good planning and (proactive) and government incentives dictates concentrated development in villages and towns and cities, leaving forests intact

- Fastest broadband exists in towns, cities, villages

- Fewer cars, less single occupancy vehicles, bike path networks, and public transit (buses???)

- Transportation infrastructure designed to provide connectivity for fish and wildlife

- Vermont is a leader in the country economically, environmentally, and aesthetically and maintains its brand 
Table A2.1. Scenario 1: Connecting, Protecting, and Thriving (CPT)

\begin{tabular}{|c|c|c|c|c|}
\hline Land use & How Much? & Where? & What kind? & Why? \\
\hline $\begin{array}{l}\text { Forest to } \\
\text { Development }\end{array}$ & $\begin{array}{l}\text { Reduction or stable loss } \\
\text { due to human population } \\
\text { growth is static and use of } \\
\text { existing available housing }\end{array}$ & $\begin{array}{l}\text { Infill in cities and } \\
\text { towns and immediate } \\
\text { periphery }\end{array}$ & $\begin{array}{l}\text { High density walkable } \\
\text { downtowns, bike paths, } \\
\text { a mix of affordable and } \\
\text { senior housing }\end{array}$ & $\begin{array}{l}\text { - } \\
\text { - } \\
\text { - } \\
\text { - Inffill groctive planning } \\
\text { - Intergenerational transfers will allow for increase } \\
\text { purchase of conservation easements (funds will be } \\
\text { available) } \\
\text { - Amore younger folks want to live in more urban } \\
\text { areas }\end{array}$ \\
\hline $\begin{array}{l}\text { Forest to } \\
\text { Agriculture }\end{array}$ & $\begin{array}{l}\text { Greatly reduced to } \\
\text { eventually no conversion }\end{array}$ & $\begin{array}{l}\text { Around existing ag } \\
\text { areas, not along } \\
\text { riparian areas or } \\
\text { floodplain forests }\end{array}$ & $\begin{array}{l}\text { Diversified, smaller } \\
\text { scale }\end{array}$ & $\begin{array}{ll}\text { - } & \text { Reduction in large scale dairy } \\
\text { - } & \text { Reduction in price support subsidies } \\
\text { - } & \text { Greater resource (water) protection standards } \\
\text { - } & \text { Diversification of ag industry } \\
\text { - } & \text { International farmland access }\end{array}$ \\
\hline $\begin{array}{l}\text { Timber } \\
\text { Harvesting }\end{array}$ & $\begin{array}{l}\text { Increase to } 10-15 \% \text { of land } \\
\text { base harvested/decade }\end{array}$ & $\begin{array}{l}\text { Private and public } \\
\text { lands }\end{array}$ & $\begin{array}{l}\text { Biomass } \\
\text { High quality timber } \\
\text { Value-added } \\
\text { Increase in uneven- } \\
\text { aged management } \\
\text { Certification required }\end{array}$ & $\begin{array}{l}\text { More government oversight in practice to ensure } \\
\text { quality of stewardship } \\
\text { More government subsidies/incentives to the } \\
\text { industry } \\
\text { - Maintaining VT brand will improve the sale- } \\
\text { ability of VT producers }\end{array}$ \\
\hline Conservation & $\begin{array}{l}50 \% \text { of land conserved by } \\
2060\end{array}$ & $\begin{array}{l}\text { Easements on private } \\
\text { lands } \\
\text { Town forests }\end{array}$ & $\begin{array}{l}\text { Core unfragmented } \\
\text { forests \& connected } \\
\text { lands } \\
\text { Key ecologically } \\
\text { important lands }\end{array}$ & $\begin{array}{l}\text { Effective for disaster mitigation } \\
\text { - } \quad \text { Improve landscape resilience for climate change } \\
\text { - } \quad \text { More funding for easement purchases reducing } \\
\text { pressure to draw value from land through } \\
\text { development } \\
\text { - Value shift on part of residents to support land } \\
\text { conservation }\end{array}$ \\
\hline
\end{tabular}




\section{Scenario 2. Little Switzerland}

Drivers: strong government with proactive planning that is in favor of working lands and population growth with climate change refugees

\section{Storyline:}

- Dense, compact downtowns and growth centers

- Large un-fragmented forests

- More existing open land utilized for farming and more farms are intensively managed

- People settle in densely but there is still some forest loss around existing settlements

- Infill development

- Energy is smaller scale generation, individual wind towers favored but not exclusively (group agnostic about this); smaller solar arrays but not exclusively, more biomass energy, more energy conservation

- More public transportation and safe biking - fewer vehicle miles traveled (per person?)

- Road network is reallocated for public transportation and biking, roads moved out of riparian areas

- $\quad$ Strong land use planning - Act 500+ 
Table A2.2. Scenario 2: Little Switzerland

\begin{tabular}{|c|c|c|c|c|}
\hline Land use & How Much? & Where? & What kind? & Why? \\
\hline $\begin{array}{l}\text { Forest to } \\
\text { Development }\end{array}$ & $\begin{array}{l}\text { More initially and decreasing through } \\
\text { time. Maybe rates of conversion } \\
\text { similar to now when averaged over } 50 \\
\text { yrs. }\end{array}$ & $\begin{array}{l}\text { Adjacent to already } \\
\text { developed areas } \\
\text { Not in riparian areas, on } \\
\text { good ag soils, or } \\
\text { ecologically important } \\
\text { areas }\end{array}$ & $\begin{array}{l}\text { Residential - mostly compact } \\
\text { housing } \\
\text { Commercial - to support larger } \\
\text { population } \\
\text { Very little energy b/c it is mixed } \\
\text { with developed land }\end{array}$ & $\begin{array}{l}\text { Large influx of people but } \\
\text { strict regs. about where they } \\
\text { settle }\end{array}$ \\
\hline $\begin{array}{l}\text { Forest to } \\
\text { Agriculture }\end{array}$ & Minimal & Little bits scattered around & $\begin{array}{l}\text { Limited land } \\
\text { Associated with homestead } \\
\text { scale agriculture }\end{array}$ & $\begin{array}{l}\text { New ag uses currently open } \\
\text { areas } \\
\text { Existing ag land is used } \\
\text { more intensively }\end{array}$ \\
\hline $\begin{array}{l}\text { Timber } \\
\text { Harvesting }\end{array}$ & $\begin{array}{l}100 \% \text { of annual growth on managed } \\
\text { timberlands }\end{array}$ & $\begin{array}{l}\text { Most of state's forestland } \\
\text { is managed timberland } \\
\text { (maybe } 90 \% \text { ) or } \sim 60 \% \text { of } \\
\text { state land base }\end{array}$ & $\begin{array}{l}\text { Cutting a lot of "energy wood" } \\
\text { to increase the proportion of } \\
\text { high value timber }\end{array}$ & $\begin{array}{l}\text { Need for energy wood, } \\
\text { building materials, and more } \\
\text { valuable wood drive a lot } \\
\text { more logging - carefully } \\
\text { planned }\end{array}$ \\
\hline Conservation & $\begin{array}{l}\sim 1 / 2 \text { of land is protected from } \\
\text { development }\end{array}$ & $\begin{array}{l}\text { Everywhere outside } \\
\text { designated growth zones }\end{array}$ & $\begin{array}{l}\text { Mostly working land easements } \\
\text { At least } 10 \% \text { ecological reserves }\end{array}$ & $\begin{array}{l}\text { States and towns } \\
\text { aggressively protect resource } \\
\text { lands thru conservation } \\
\text { easements, public } \\
\text { ownership, etc. }\end{array}$ \\
\hline
\end{tabular}




\section{Scenario 3: Darkness on the Edge of Town}

Drivers: minimal government involvement, high value placed on supporting free market and population growth with climate change refugees

\section{Storyline:}

- Rapid development across the landscape; sprawl with single family development; large developments in urban areas

- Increase in population could be a positive for downtowns

- Less public land; no new conservation; land sold off for development

- Developers "pay as you go" structure; infrastructure is privatized

- Increase in students in; better finances for schools (not necessarily better schools)

- Skewed towards large consolidated farms/forestry (high demand for food/energy); loss of small ownerships

- Parcelized land patterns leading to fragmented/converted forest

- Energy production from fracked natural gas "status quo"

- Visit nature online/travel for recreation due to lack of public access 
Table A2.3. Scenario 3: Darkness on the Edge of Town

\begin{tabular}{|c|c|c|c|c|}
\hline Land use & How Much? & Where? & What kind? & Why? \\
\hline $\begin{array}{l}\text { Forest to } \\
\text { Development }\end{array}$ & 10x current rate & $\begin{array}{l}\text { Adjacent to transportation } \\
\text { corridors } \\
\text { Radiating out from urban } \\
\text { center } \\
\text { Rural sprawl } \\
\text { Slope }<20 \%\end{array}$ & $\begin{array}{l}\text { Single family and multi-unit } \\
\text { housing, P.U.D. }\end{array}$ & $\begin{array}{l}\text { An increase in the population with little } \\
\text { government oversight and planning } \\
\text { leads to an increase in forest } \\
\text { conversation to development, cheaper } \\
\text { in the rural landscape }\end{array}$ \\
\hline $\begin{array}{l}\text { Forest to } \\
\text { Agriculture }\end{array}$ & $\begin{array}{l}50 \% \text { increase over annual } \\
\text { current loss ( } 300 \text { acres } \\
\text { /year) }\end{array}$ & Where prime ag soils exist & Large scale farming & $\begin{array}{l}\text { An increase in large consolidation of } \\
\text { farms with some conversion needed to } \\
\text { support the growing population }\end{array}$ \\
\hline $\begin{array}{l}\text { Timber } \\
\text { Harvesting }\end{array}$ & $\begin{array}{l}\text { Less land area (4\% per } \\
\text { decade) } \\
\text { Increase in amount of } \\
\text { board feet }\end{array}$ & $\begin{array}{l}\text { Everywhere where there is } \\
\text { access }\end{array}$ & $\begin{array}{l}\text { Biomass unregulated } \\
\text { forestry, highgrading }\end{array}$ & $\begin{array}{l}\text { An increase in the population leads to } \\
\text { parcelization and lack of access to } \\
\text { forests, as well as disconnected public } \\
\text { which does not support forestry }\end{array}$ \\
\hline Conservation & $\begin{array}{l}\text { None/year first } 25 \text { years } \\
\text { Second } 25 \text { years actually } \\
\text { sell off } 1000 \text { acres } \\
\text { conserved land per year }\end{array}$ & Everywhere & $\begin{array}{l}\text { If conservation occurs at all } \\
\text { it is privately conserved but } \\
\text { selling off of public lands, } \\
\text { still makes a net loss }\end{array}$ & $\begin{array}{l}\text { An increase in population has led to a } \\
\text { halt in conservation and actually a } \\
\text { selling of land }\end{array}$ \\
\hline
\end{tabular}




\section{Scenario 4: Post It If You Can}

Drivers: minimal government involvement, high value placed on supporting free market and population change is status quo/declining

\section{Storyline:}

- Population distribution - higher stratification between those w/ resources and w/o resources; education/no education

- Scattered development, rural sprawl

- Mix of kingdom lots and development lots

- Landownership more driven by those with means; higher property values in areas closer to valued amenities; decreasing ownerhship/increasing rental

- Energy production could be more fossil fuel-based from outside VT; more ridgeline energy development; biomass plants; purchased isolation

- Whatever makes money

- Food production is less local, fewer and larger farms, alternative - more support for local production; GMOs are universal; new crops

- Transportation is car-centric; fewer public transit options; poor infrastructure/crumbling; short-sighted planning; more private airstrips

- Less land use policy, if you can afford it - you can do it approach to land use planning

- Public lands that remain are overused, under-maintained, commercialized, over-priced

- Natural disturbance has flooding but no land use regulations to help

- Resources like water become a commodity, water quality is degraded 
Table A2.4. Scenario 4: Post It If You Can

\begin{tabular}{|c|c|c|c|c|}
\hline Lad use & How Much? & Where? & What kind? & Why? \\
\hline $\begin{array}{l}\text { Forest to } \\
\text { Development }\end{array}$ & $\begin{array}{l}10 \% \text { conversion from } \\
\text { forest to development }\end{array}$ & $\begin{array}{l}\text { Areas with more } \\
\text { amenities/services (i.e., } \\
\text { Chittenden County) }\end{array}$ & $\begin{array}{l}\text { Residential } \\
\text { development } \\
\text { Kingdom lots }\end{array}$ & $\begin{array}{l}\text { - High-end residential development } \\
\text { - Higher end property ownership } \rightarrow \\
\text { some rural sprawl but concentrated in } \\
\text { pocket areas close to amenities and } \\
\text { services }\end{array}$ \\
\hline $\begin{array}{l}\text { Forest to } \\
\text { Agriculture } \\
\end{array}$ & $\begin{array}{l}\text { Increase of }>1 \% \text { of forest } \\
\text { to ag }\end{array}$ & $\begin{array}{l}\text { Not in currently developed } \\
\text { areas, prime ag soi } \\
\text { locations, level terrain }\end{array}$ & $\begin{array}{l}\text { GMO crops and all } \\
\text { kinds of monoculture, } \\
\text { vineyard }\end{array}$ & $\begin{array}{l}\text { Due to wetter circumstances (i.e., } \\
\text { increase precip rate/events) there } \\
\text { could be an increase in agriculture in } \\
\text { VT }\end{array}$ \\
\hline $\begin{array}{l}\text { Timber } \\
\text { Harvesting }\end{array}$ & $\begin{array}{l}\text { Patchwork across the state } \\
\text { - very intense to none at all } \\
\text { (state parks being none at } \\
\text { all) } \\
\text { Could increase by } 16-24 \%\end{array}$ & $\begin{array}{l}\text { Private land } \\
\text { Areas bought up by high } \\
\text { buyers }\end{array}$ & $\begin{array}{l}\text { Unregulated timber } \\
\text { harvesting for biomass }\end{array}$ & $\begin{array}{l}\text { - No regulations or UVA requirements } \\
\text { - Unregulated climate increase biomass } \\
\text { and clearcutting or highgrading } \\
\text { - No current use program }\end{array}$ \\
\hline Conservation & Loss of $80 \%$ & $\begin{array}{l}\text { Statewide but some } \\
\text { viewshed protection }\end{array}$ & N/A & $\begin{array}{ll}- & \text { Loss of conserved land overall } \\
\text { - } & \text { Public lands sold for profit/public } \\
\text { interest }\end{array}$ \\
\hline
\end{tabular}


Massachusetts Scenario Workshop Summary

October 5, 2015

Division of Fisheries and Wildlife Headquarters, Westborough, MA

High mobility / slippery

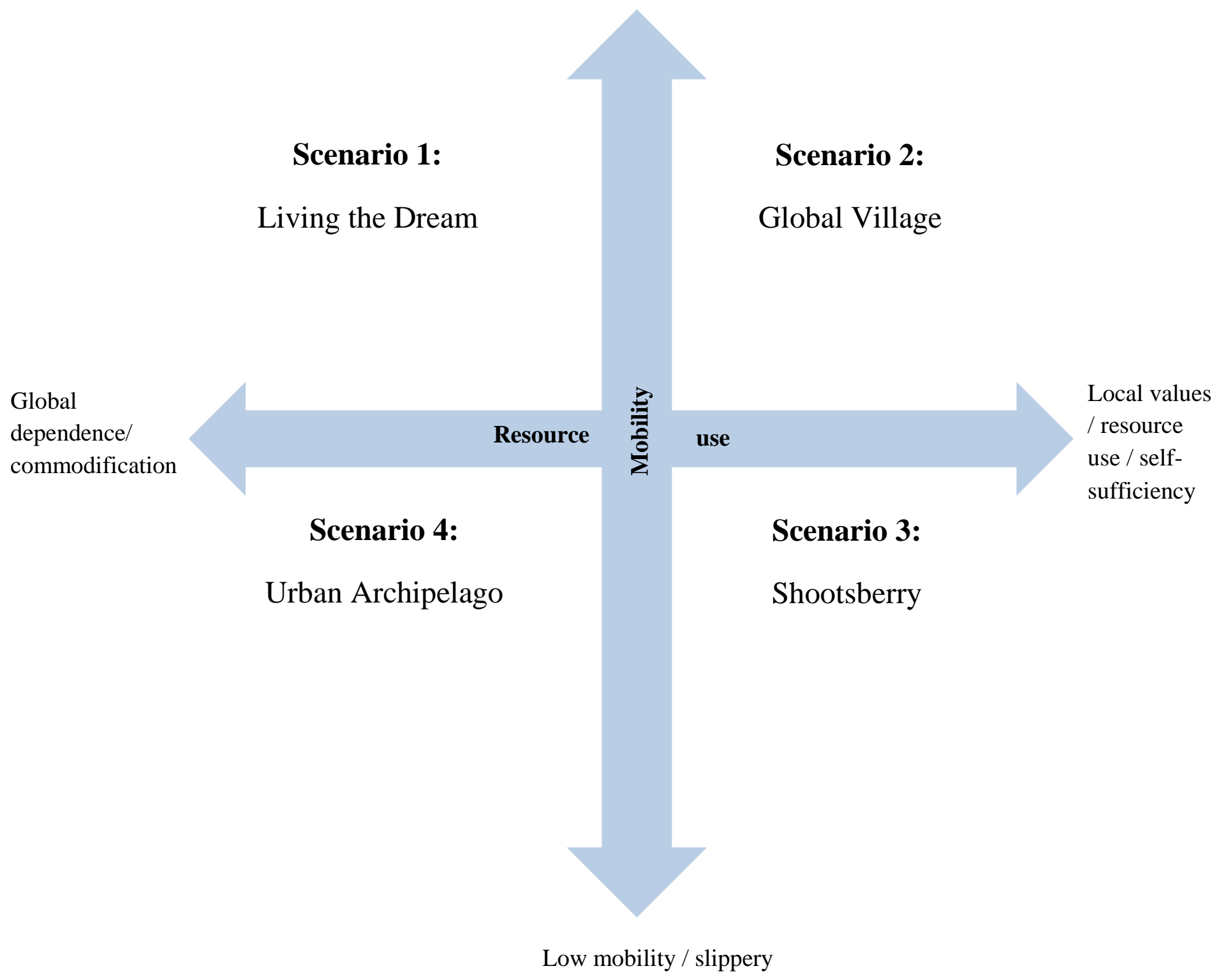

Fig. A2.2. Massachusetts scenario matrix 


\section{Scenario 1: Living the Dream (in Massachusetts)}

Drivers: global dependence/commodification and high mobility/slippery

\section{Storyline:}

- Saw not just MA alone, but considered that these drivers and impacts would also move into/be linked to the broader NE region; they decided 'high mobility' focus on transportation

- Envisioned that people could live and work anywhere. This would put pressure on land. With business as usual there would be more pressure to develop forests around transportation nodes. (If there were the right incentives, transferable development rights (TDRs), carbon tax could flip that around.)

- Heavy inland pressure into the interior of Massachusetts.

- The slipper mobility changes the politics, Boston is less important. Boston under sea level rise, extreme weather, providing some incentives for the politics to change.

- Cheap commodities available globally leading to the proliferation of WalMarts and other big box stores

- However, the potential potential exists for the region to model how shifts in economies globally and advance fair trade regimes

- Tension and redistribution of population would drive up property values in Western MA, but also possible influence of ecosystem service and carbon markets. Reshuffling population, but not a given that any one future land use would come from that.

- Mobility making it more clear that this is a region. Regional economy.

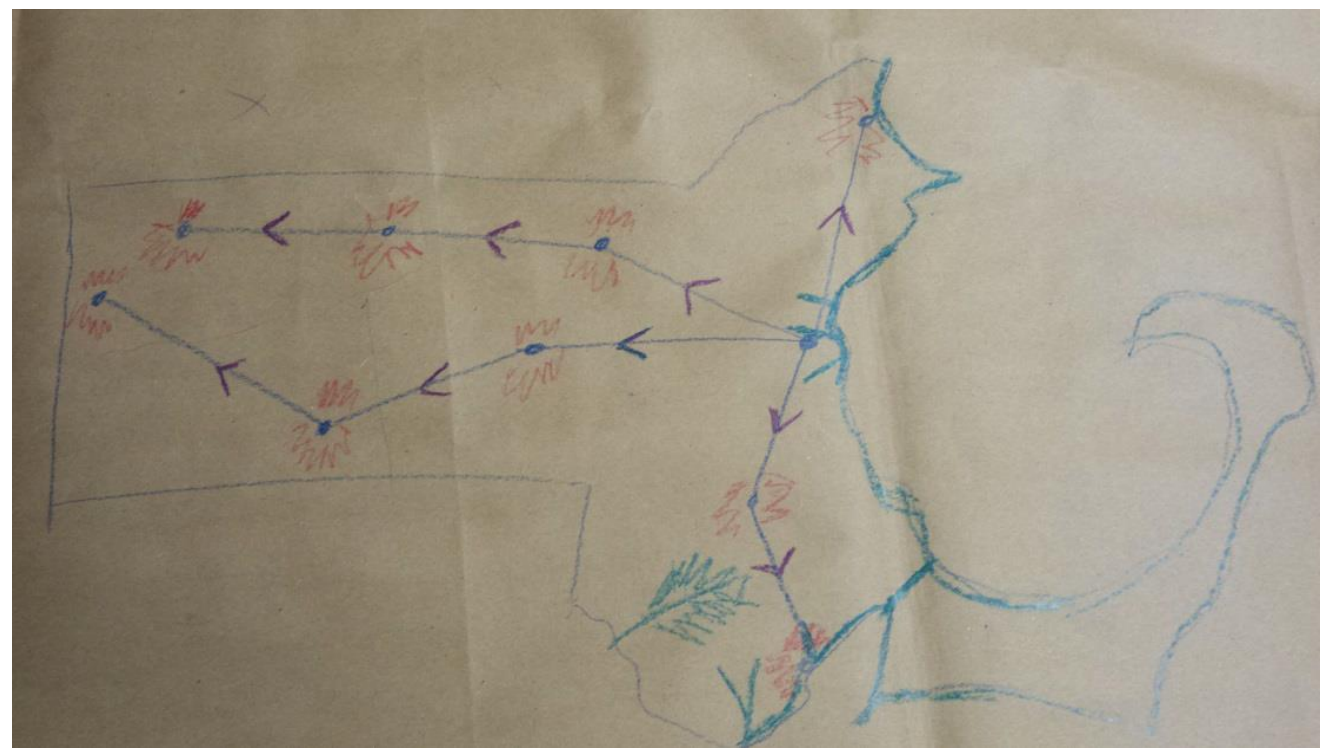


Table A2.5. Scenario 1: Living the Dream

\begin{tabular}{|c|c|c|c|c|}
\hline Land use & How Much? & Where? & What kind? & Why? \\
\hline $\begin{array}{l}\text { Forest to } \\
\text { Development }\end{array}$ & $\begin{array}{l}\text { Increase } \\
8,000-10,000 \text { acres/year }\end{array}$ & $\begin{array}{l}\text { Around transportation nodes (i.e., } \\
\text { small cities), some more diffuse } \\
\text { (home offices) because some } \\
\text { transportation improvement will be } \\
\text { road based this will lend to more } \\
\text { diffuse sprawling development }\end{array}$ & $\begin{array}{l}\text { Housing and } \\
\text { commercial, more } \\
\text { housing, some } \\
\text { alternative energy - } \\
\text { e.g., wind and solar }\end{array}$ & $\begin{array}{l}\text { Transportation improvements and } \\
\text { lower travel times, fuel, diffuse } \\
\text { growth }\end{array}$ \\
\hline $\begin{array}{l}\text { Forest to } \\
\text { Agriculture }\end{array}$ & $\begin{array}{l}\text { No change } \\
\text { Continued slow loss of } \\
\text { agriculture land to forest } \\
\text { succession }\end{array}$ & Rural areas of MA & & $\begin{array}{l}\text { Local cant's compete on cost - no } \\
\text { increase, possible decreased } \\
\text { demand for local produce }\end{array}$ \\
\hline $\begin{array}{l}\text { Timber } \\
\text { Harvesting }\end{array}$ & $\begin{array}{l}\text { Boom - bust } \\
\text { Increase harvesting at first, } \\
\text { trending down toward end of } 50 \\
\text { years }\end{array}$ & $\begin{array}{l}\text { Central and western MA - some in } \\
\mathrm{NE} \text { and SE }\end{array}$ & Fueled by market & $\begin{array}{l}\text { Global markets initially fuel } \\
\text { increased overseas demand, little } \\
\text { regulation over, over time prices } \\
\text { decline --- also increased } \\
\text { development into smaller parcels } \\
\text { over time lowest feasibility of } \\
\text { harvest - land available for harvest }\end{array}$ \\
\hline Conservation & $\begin{array}{l}\text { Rate will state same as present } \\
\text { for forest } 25 \text { years, then rate will } \\
\text { decline to some degree }\end{array}$ & Central, west, and SE MA & $\begin{array}{l}\text { State, local, NGO fee } \\
\text { acquisition }\end{array}$ & $\begin{array}{l}\text { As landscape is developed and new } \\
\text { pop centers energize willingness to } \\
\text { pay will go up. However } \\
\text { availability of suitable parcels } \\
\text { (opportunity) will go down. } \\
\text { Observed climate change may } \\
\text { increase political will; willing to to } \\
\text { act over time }\end{array}$ \\
\hline
\end{tabular}




\section{Scenario 2: Global Village}

Drivers: locally centered and globally connected

\section{Storyline:}

- Local dependence/resource use and high mobility/slippery

- Facilitators note: there is some tension on drivers and endpoints in this scenario. The craft paper shows questions about policy interventions. One way to resolve this might be to think about change over time. Could there be more sprawl and development and less efficient use of resources at the beginning of the time period but the impacts eventually incentive policy shifts to prevent "loving the landscape to death"?

- Transportation and high speed rail lead to increased population in western Mass

- More people moving around in a rapid way

- Exurban growth

- Loved to death

- New people coming in all the time, disruptive to maintaining community feel

- Policies follow - put people into landscape smartly? Smart growth?

- Have it all - people and protected lands

- working landscapes to produce local resources

- Local: recreation, forest and ag products, ecosystem services, critters

- Also value local landscape: want protection and conservation

- Policy needs and landowners incentives so people don't get their 2 acres anymore

- Housing/spacing

- Milltowns

- Zoning regs or easements

- Tax incentives

- Strong value of local products and goods in a very mobile world. This valuing of local things isn't just locally valued. More people coming into our area, but policies and incentives adjust to protect forest.

- Working landscapes

- Farmland (pasture, hayfields)

- Physical mobility can bring in invasive species

- Burning a lot of energy but more efficiently

- Local energy production - virtually all infrastructure would be solar roofs; residential and commercial solar; hi-tech battery storage

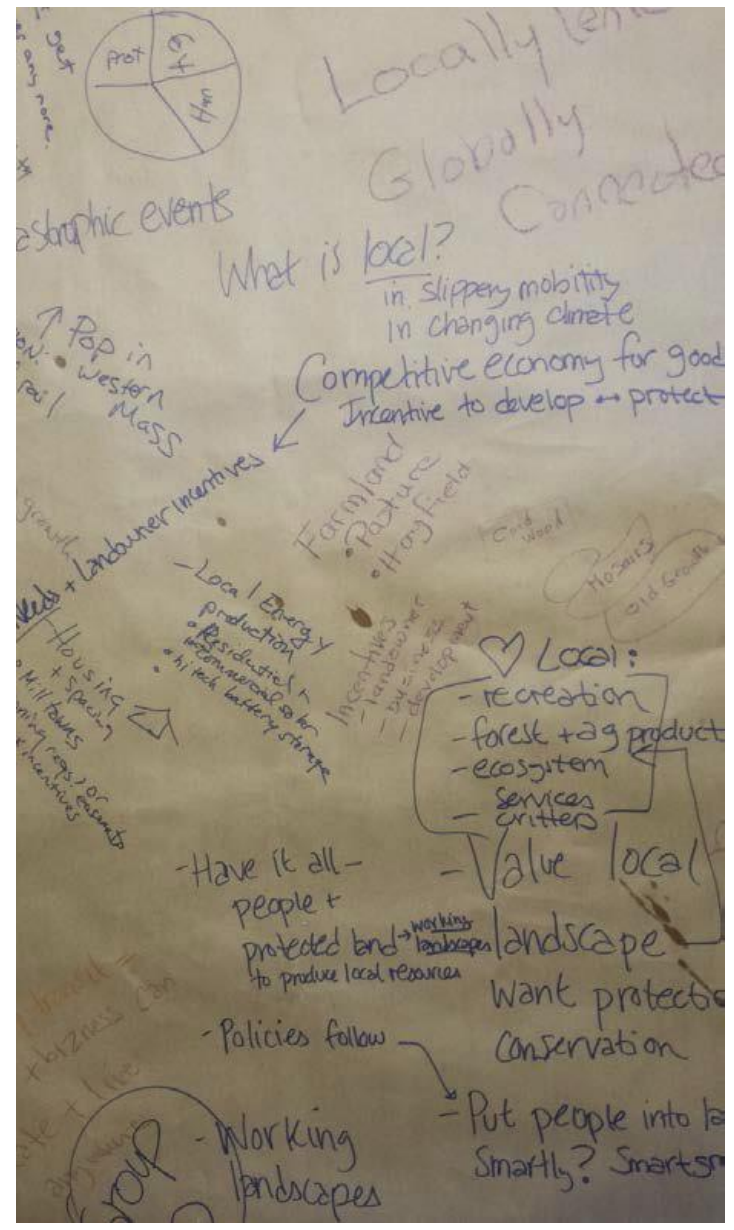


Table A2.6. Scenario 2: Global Village

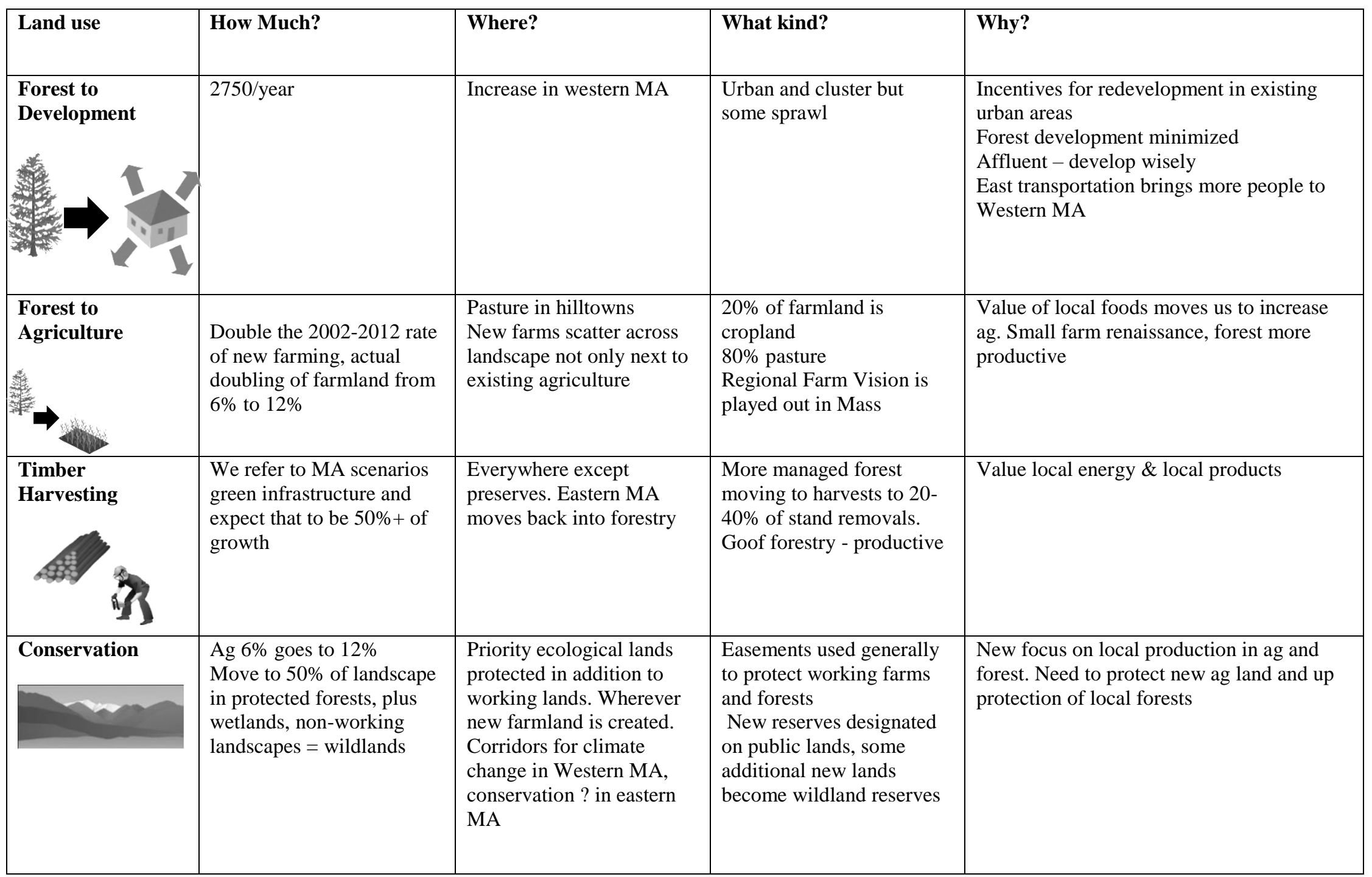




\section{Scenario 3: Shootsberry 2060 AKA "Pub Life"}

Drivers: local dependence/resource use and low mobility/sticky --like our culture but can't go too far

\section{Storyline:}

\section{PROS:}

- Energy produced locally - solar, wind, water (dams)

- Efficient, woodlots used efficiently

- Highly efficient houses

- Electric cars

- The need for food is very important and leads to more coordinated effort to use the best soils for production -- intensive production, backyard, schoolyward on good soils - open lands

- Backyards, schoolyards, more development in village centers, coming together in communities, pub life (knowing land), a lot of our work is centered around producing for daily needs but also medical needs

- Village centers increase

\section{CONS:}

- $\quad$ Trapped and vulnerable - trans $=$ work

- Space conflicts/shortages/no grid

- Energy use more controversial around how we use landscapes for solar and wind

- More landscape fragmentation

- More energy shortage

- More food limitations and malnutrition

- More cabin fever, more of a fortress mentality

- Worries about long term care and vulnerability of the community at large

- Less income growth potential

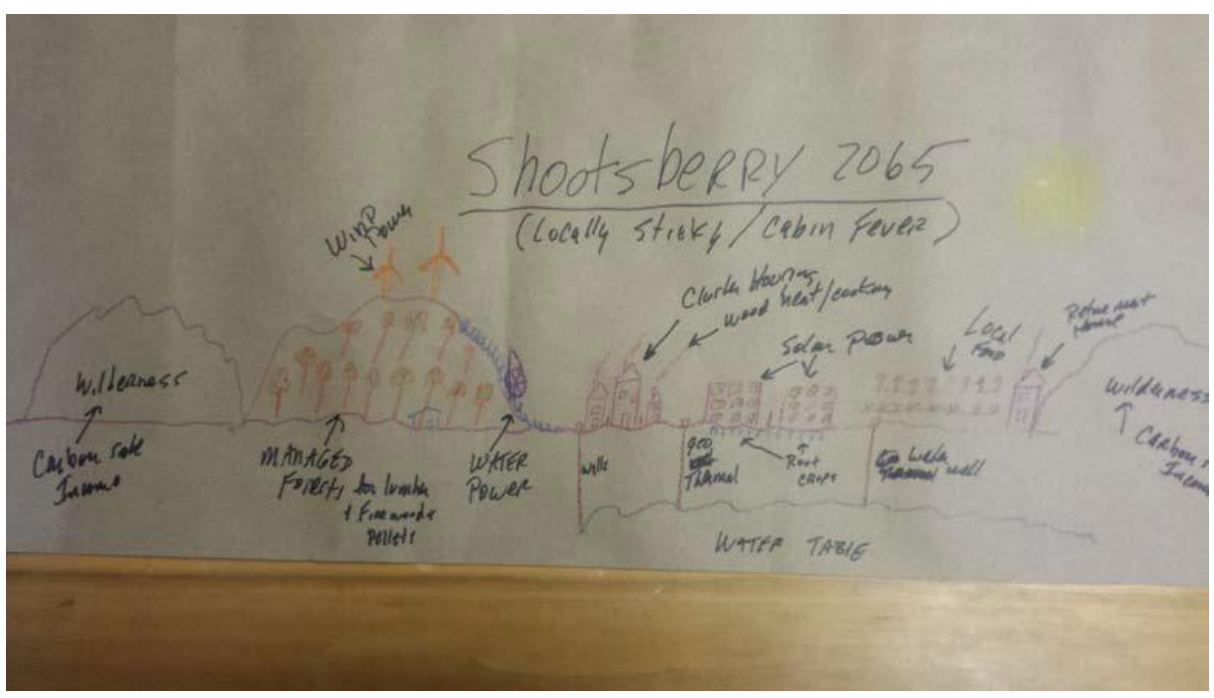


Table A2.7. Scenario 3: Shootsberry

\begin{tabular}{|c|c|c|c|c|}
\hline Land use & How Much? & Where? & What kind? & Why? \\
\hline $\begin{array}{l}\text { Forest to } \\
\text { Development }\end{array}$ & Less than current & $\begin{array}{l}\text { Poorest soils, near } \\
\text { infrastructure }\end{array}$ & $\begin{array}{l}\text { Cluster co-housing, some multi- } \\
\text { family necessary, apartments, } \\
\text { farmsteads }\end{array}$ & $\begin{array}{l}\text { Forests more valuable for } \\
\text { harvest/mgmt., population is stable } \\
\text { but less mobile }\end{array}$ \\
\hline $\begin{array}{l}\text { Forest to } \\
\text { Agriculture }\end{array}$ & Much more & $\begin{array}{l}\text { Appropriate soils/sites for } \\
\text { type of ag } \\
\text { As residential accessory } \\
\text { use }\end{array}$ & $\begin{array}{l}\text { Away from energy intense - see } \\
\text { "New England Food Vision" } \\
\text { Suitable for year-round } \\
\text { consumption } \\
\text { Barter and trade }\end{array}$ & Food supply \& security \\
\hline $\begin{array}{l}\text { Timber } \\
\text { Harvesting }\end{array}$ & More than current & $\begin{array}{l}\text { Best forest soils avoid } \\
\text { conflict with ag }\end{array}$ & Sustainable advanced silviculture & $\begin{array}{l}\text { Replace most import/export with } \\
\text { local market }\end{array}$ \\
\hline Conservation & $\begin{array}{l}\text { More to ensure lands are } \\
\text { available }\end{array}$ & Best for forestry, ag, water & $\begin{array}{l}\text { Incentives, planning, land use } \\
\text { regulations }\end{array}$ & $\begin{array}{l}\text { \$ to landowners in exchange for } \\
\text { conservation land in public interes }\end{array}$ \\
\hline
\end{tabular}




\section{Scenario 4: Urban Archipelago}

Drivers: global dependence/commodification and low mobility/sticky

\section{Storyline:}

\section{PROS:}

- Shift to people living more in urban areas, harder to get around

- Better for forest (increase in forest cover)

- Less demand for forest products, global commodities would be so cheap that many forests would be unused

- Strengthening of community because there is less ability to leave where you live. Strong community. Compared it to early settlers who lived in isolated way. Had to sell best goods to export

- Less sprawl and congestion

\section{CONS:}

- Lower economic growth and mobility

- Lower quality of life: only people with lots of money $\square$ more access to cars and internet. Big income disparity and mobility disparity

- Quality of life = low. No option to change the quality of life by working hard

- People are less able to pull themselves up by their bootstraps. Hard to change life by working hard

- Retirement community (Shutesbury - where would you rather be)?

- Island culture - cannot leave, have to buy in:

- Japan

- Marthas Vineyard

- Hawaii

- Aruba
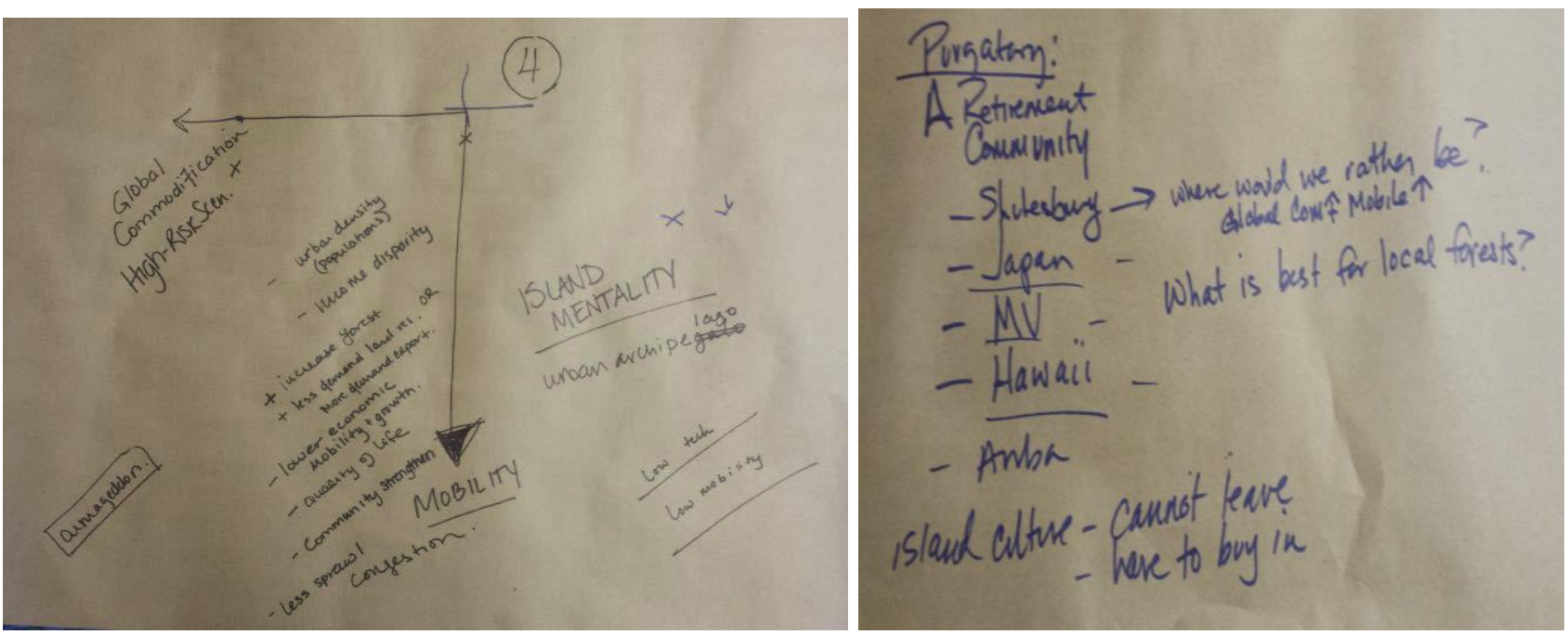
Table A2.8. Scenario 4: Urban Archipelago

\begin{tabular}{|c|c|c|c|c|}
\hline Land use & How Much? & Where? & What kind? & Why? \\
\hline $\begin{array}{l}\text { Forest to } \\
\text { Development }\end{array}$ & $\begin{array}{l}\text { Would slow over time } \\
\text { Start at } 16,000 \text { acres per year, decline } \\
\text { to } 5,000\end{array}$ & $\begin{array}{l}\text { Dense areas will become denser. } \\
\text { Areas that are already urban will } \\
\text { increase density }\end{array}$ & $\begin{array}{l}\text { Residential - people moving to } \\
\text { urban areas. } \\
\text { Mixed use. }\end{array}$ & $\begin{array}{l}\text { More press in urban } \\
\text { forests - more } \\
\text { development }\end{array}$ \\
\hline $\begin{array}{l}\text { Forest to } \\
\text { Agriculture } \\
\end{array}$ & $\begin{array}{l}\text { Increase forest to farmland on smaller } \\
\text { scale; possibly also lose farmland } \\
\text { acres }\end{array}$ & Rural & Small scale & $\begin{array}{l}\text { No market for local } \\
\text { goods }\end{array}$ \\
\hline Timber & $\begin{array}{l}\text { Less timber locally } \\
\text { More competition from global } \\
\text { markets and less local forestry }\end{array}$ & $\begin{array}{l}\text { Family owned businesses - rural } \\
\text { landscape }\end{array}$ & Local, fuel local use, firewood & Expensive to ship \\
\hline Conservation & $\begin{array}{l}\text { Smaller parcels } \\
\text { More land conservation would } \\
\text { continue but pace might slow }\end{array}$ & Rural & Smaller scale & $\begin{array}{l}\text { Less opportunity and } \\
\text { need for stewardship }\end{array}$ \\
\hline
\end{tabular}




\section{Maine Scenario Workshop Summary}

October 16, 2015

New England Environmental Finance Center, University of Southern Maine

Population and economic growth in response to

climate change (e.g., Maine is "safe zone")

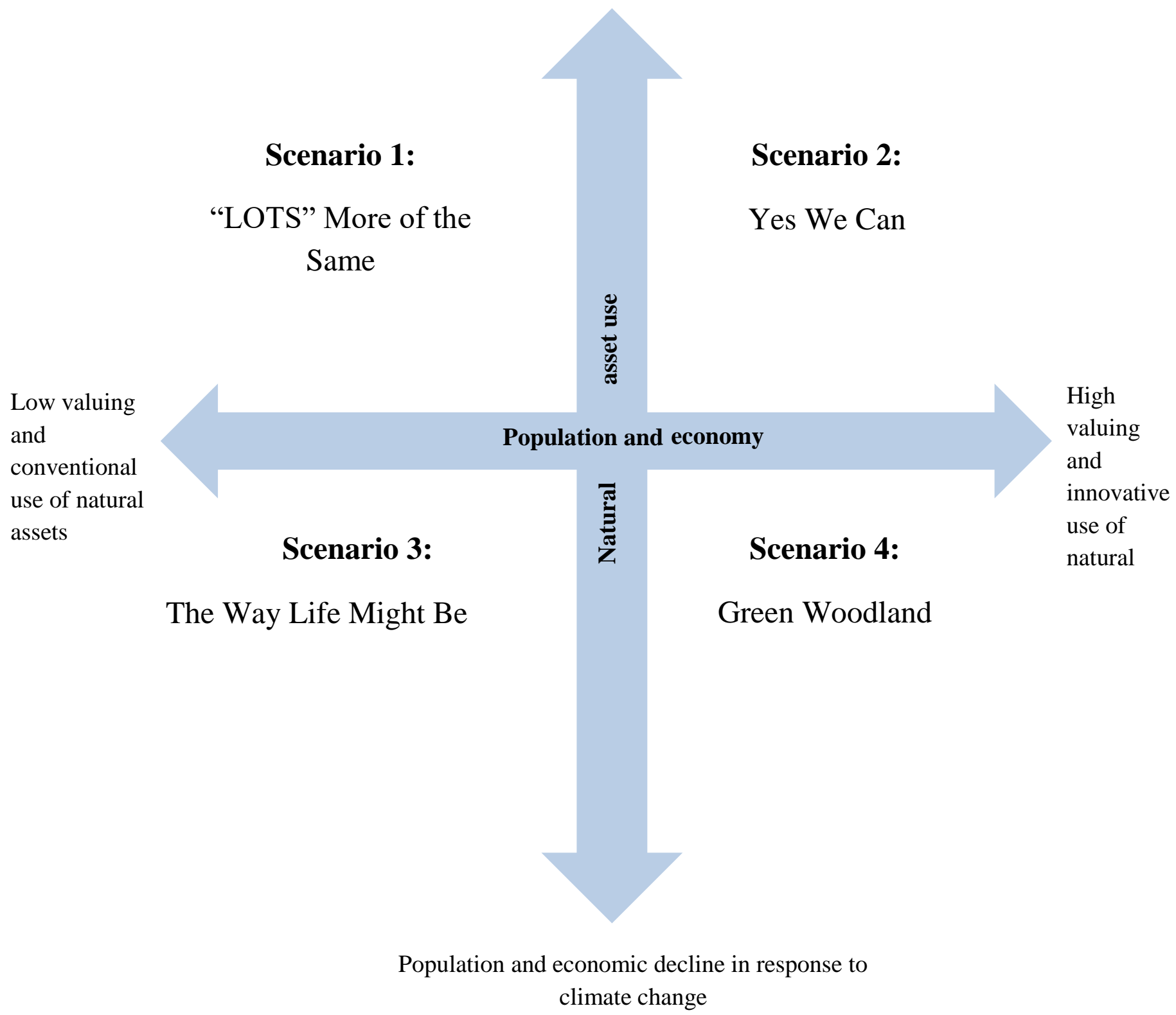

Fig. A2.3. Maine scenario matrix 
Maine Scenario Workshop 10.1615

New England Environmental Finance Center, University of Southern Maine, ME

\section{Scenario 1. "LOTS" More of the Same}

Drivers: population and economic growth in response to climate change, combined with low valuing and conventional use of natural assets

\section{Storyline:}

- Growth in population, associated growth in economic opportunity

- Conventional natural resource use

- Assuming what we have already, but more of it

- Because there are more people, more people are in the way of natural disasters.

- We would see development sprawl ("lots"), particularly around existing population centers and lakes, with suburban growth nearby (places that have experienced sprawl in the past)

- Likely a higher standard of living, because more economic opportunity

\section{PROS:}

- A younger, more diverse population

- Higher standard of living may lead to bigger houses (?)

- Better health care

- More education opportunities

- Continued local food production

CONS:

- Increase in impervious surfaces, and increase in extraction of natural innovation (water, wood

- harvesting)

- A need for more roads, and vehicles for catering for to growing population

- More land ownership fragmentation $\rightarrow$ smaller parcels

- More degraded environment:

- Loss of biodiversity

- Reduced air, water quality

○ Negative effects on fisheries

- More pressure on local agricultural lands

- More tourism, but changed recreational opportunities (less wild now)

- More energy and utility development / water \& sewer infrastructure

- More vector borne disease

- Less trust and feeling safe outside

- ? of rural communities and related institutions \& services / still have 2 Maines

* Note: couldn't decide what the economic growth driver would be. The stated assumption from the drivers discussion is that Maine's status as a climate change "safe zone" - brings refugee and people who want to relocate there, would also attract businesses, investment, etc. 
Maine Scenario Workshop 10.1615

New England Environmental Finance Center, University of Southern Maine, ME

Table A2.9. Scenario 1: "LOTS" More of the Same

\begin{tabular}{|c|c|c|c|c|}
\hline Land use & How Much? & Where? & What kind? & Why? \\
\hline $\begin{array}{l}\text { Forest to } \\
\text { Development }\end{array}$ & $\begin{array}{l}\text { In } 50 \text { years on average, about } \\
2000 \text { acres/year is lost from } \\
\text { forest to development. }\end{array}$ & $\begin{array}{l}\text { Most }(75 \%) \text { of forest } \\
\text { conversion is adjacent to } \\
\text { existing community } \\
\text { centers, roads, networks } \\
\text { \& lakes. More } \\
\text { development in southern } \\
\text { counties. }\end{array}$ & $\begin{array}{l}\text { Mostly residential, mostly } \\
\text { small lot development with } \\
\text { some rural 2-acre lot } \\
\text { development in southern } \\
\text { Maine }\end{array}$ & $\begin{array}{l}\text { The conversion is a result of the high } \\
\text { influx of in-migration related to the } \\
\text { desirability of the environment as a } \\
\text { place to live and recreate and need for } \\
\text { housing, some seasonal homes, about a } \\
30 \% \text { increase in population }\end{array}$ \\
\hline $\begin{array}{l}\text { Forest to } \\
\text { Agriculture }\end{array}$ & $\begin{array}{l}\text { Slight increase in agriculture - } \\
450 \text { new farms in } 50 \text { years, } 1- \\
2 \% \text { increase in land area }\end{array}$ & $\begin{array}{l}\text { Near other small } \\
\text { agriculture as well as } \\
\text { near population centers }\end{array}$ & $\begin{array}{l}\text { Small-scale farms; row } \\
\text { crops }\end{array}$ & $\begin{array}{l}\text { Continued interest in local farms \& } \\
\text { foods }\end{array}$ \\
\hline $\begin{array}{l}\text { Timber } \\
\text { Harvesting }\end{array}$ & $\begin{array}{l}\text { Reduced timber harvesting in } \\
\text { southern part of state; potential } \\
\text { increase in northern areas; } \\
\text { resulting in approx. 500,000 } \\
\text { acres/year }\end{array}$ & $\begin{array}{l}\text { Mostly northern Maine, } \\
\text { slightly reduced in } \\
\text { southern areas }\end{array}$ & Same conventional practices & $\begin{array}{l}\text { Corporate forestland owners remain } \\
\text { predominant in Maine's north woods; } \\
\text { small woodlot owners feel pressure to } \\
\text { cut \& sell for development }\end{array}$ \\
\hline Conservation & $\begin{array}{l}\text { The total amount of } \\
\text { conservation land each year } \\
\text { stays about the same or increase } \\
\text { slightly (though one respondent } \\
\text { said "decrease") }\end{array}$ & $\begin{array}{l}\text { Out from population } \\
\text { centers; fewer large } \\
\text { tracts to protect; smaller } \\
\text { parcels protected; new } \\
\text { models of conservation } \\
\text { emerge to target fast- } \\
\text { growing areas; southern } \\
\text { Maine \& western Maine }\end{array}$ & $\begin{array}{l}\text { Trails, waterfront access } \\
\text { (small parcels out from } \\
\text { population centers) in } \\
\text { southern Maine } \\
\text { Target climate change - } \\
\text { fewer larger projects have } \\
\text { this focus and they are in } \\
\text { northern Maine }\end{array}$ & $\begin{array}{l}\text { Continued support for land } \\
\text { conservation locally; more experience } \\
\text { to protect land } \\
\text { Reduced willingness of northern } \\
\text { corporate landowners to sell } \\
\text { easements; where there is conservation } \\
\text { there is a focus on more train } \\
\text { connectors through state/towns for } \\
\text { people to use }\end{array}$ \\
\hline
\end{tabular}


Maine Scenario Workshop 10.1615

New England Environmental Finance Center, University of Southern Maine, ME

\section{Scenario 2: Yes We Can (We can do it all!)}

Drivers: this scenario was defined by high population, and increase valuing and innovative use of natural resources

\section{Storyline:}

PROS:

- High economic equity

- Social sustainability would increase

- Increased higher education background, people that can work anywhere (artists, tech, PhDs)

- Hubs of concentrated growth

- Off grid living can be anywhere

- Innovation - can live anywhere, so real potential for off the grid anywhere, and/or work wherever (debate on this)

- Urban farming, locavore, framing techniques more effective

- Innovation/biofuels change community but low population

CONS:

(most of these seem to be associated with the inner sphere of this quadrant where there would be high population and less innovation)

- If we have a higher population and - could have more sprawl, develop more, costs more money to live here

- Resource extraction increase more probable

- We would have work force living issues

- Global immigration pressures

- Decreased environmental experiences, as the interest and connection to tech increases, and potential to increase the environment will decrease

- Exacerbated seasonality

(Note: this group broke the scenario into quadrants within it. In the discussion, they were encouraged to focus on the outer poles of the drivers) 
Maine Scenario Workshop 10.1615

New England Environmental Finance Center, University of Southern Maine, ME

Table A2.10. Scenario 2: Yes We Can

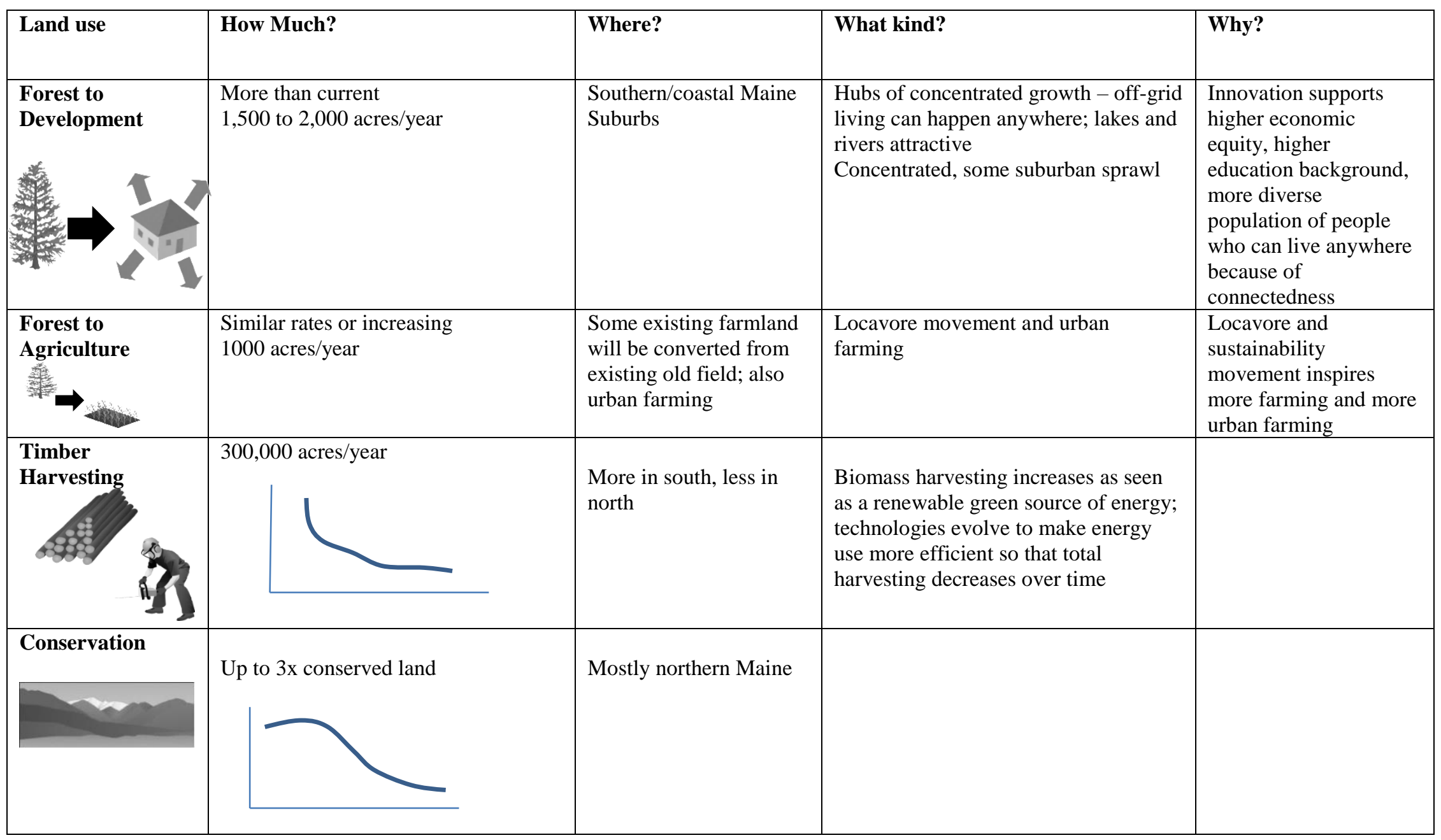


Maine Scenario Workshop 10.1615

New England Environmental Finance Center, University of Southern Maine, ME

\section{Scenario 3: The Way Life Might Be}

Drivers: population and economic decline in response to climate change, combined with low valuing and conventional use of natural assets

\section{Storyline:}

- Low valuing and conventional use of natural assets

- Population and economic decline

- Maine becomes sacrifice zone/strategic forest reserve for the nation

PROS:

- Still demand for seasonal camps - that is still a part of the future they see CONS:

- No local advocacy or stakeholder groups

- Forest crop and energy production is prioritized

- Loss of market for wood and hard to find workers for extraction jobs

- Human footprint dark spot is bigger

- Plantation and mono-tcropping common / greenhouse farming

- Broken/aging infrastructure - no investment in transportation; road abandonment

- Deterioration of natural resource regulation to drive economic growth

- Population continue along coast and aggregated land ownership

- Private funding of public infrastructure

- Loss of traditional crops

- Factory fishing

- Increase volume in forests and change in wildlife/species composition

- Abandoned buildings - attractive nuisance

- No clean-up of environmental issues

- Bunch of old farts

- No proactive mitigation or adaptation to climate change

- If current trajectory continues, lose some of the small towns that depend on the mill economy

- Continued loss of people who have good jobs because economic opportunities won't be there

- Increasing extraction of water (?) 
Maine Scenario Workshop 10.1615

New England Environmental Finance Center, University of Southern Maine, ME

Table A2.11. The Way Life Might Be

\begin{tabular}{|c|c|c|c|c|}
\hline Land change & How Much? & Where? & What kind? & Why? \\
\hline $\begin{array}{l}\text { Forest to } \\
\text { Development }\end{array}$ & $\begin{array}{ll}\text { - } & 20 \% \text { in southern Maine } \\
\text { - } & 0 \% \text { in North } \\
\text { - } & \text { Continue or declining by } 10 \% \\
\text { - } & \text { Decrease in North and West } \\
\text { - } & \text { Increase in southern coast }\end{array}$ & $\begin{array}{l}\text { - Coastal southern } \\
\text { Maine by rec areas; } \\
\text { on the "new" coast } \\
\text { created by climate } \\
\text { change } \\
\text { - In cities and urban } \\
\text { areas } \\
\text { - North - none }\end{array}$ & $\begin{array}{ll} & \text { Mostly for housing and } \\
\text { - } & \text { Cluster much for commercial } \\
\text { - } & \text { Urban areas, condos, } \\
\text { seasonal homes }\end{array}$ & $\begin{array}{l}\text { Lack of economic opportunity in } \\
\text { the North } \\
\text { Coastline change } \\
\text { Continued modest economic } \\
\text { slowdown }\end{array}$ \\
\hline $\begin{array}{l}\text { Forest to } \\
\text { Agriculture }\end{array}$ & $\begin{array}{l}\text { - } 0 \% \text { to a couple of acres per year } \\
\text { - Could be limited possibility of } \\
\text { fast-growing trees such as acacia }\end{array}$ & $\begin{array}{l}\text { - Urban farming } \\
\text { - } \quad \text { Mostly on } \\
\text { converted ag land }\end{array}$ & $\begin{array}{l}\text { - Organic veg production in } \\
\text { southern Maine } \\
\text { - Monocrops to feed other } \\
\text { states and animals }\end{array}$ & $\begin{array}{l}\text { Plenty abandonded hayfields } \\
\text { Drivers are too weak for huge } \\
\text { increases }\end{array}$ \\
\hline $\begin{array}{l}\text { Timber } \\
\text { Harvestir }\end{array}$ & $\begin{array}{l}\text { - Continue at same rate to decline } \\
\text { by } 10 \% / \text { year }\end{array}$ & $\begin{array}{l}\text { Mostly in northern } \\
\text { Maine } \\
\text { Some western Maine }\end{array}$ & $\begin{array}{l}\text { Mostly selection forestry with } \\
\text { some plantation forestry, shift } \\
\text { to softwood wood products } \\
\text { under climate change }\end{array}$ & $\begin{array}{l}\text { Continued interest by wealthy for } \\
\text { long-term investment }\end{array}$ \\
\hline Conservation & $\begin{array}{l}\text { Continue at same rate with a } \\
\text { decline over time by } 50 \% \text { as } \\
\text { opportunities in north dry up and } \\
\text { land values in south increase }\end{array}$ & $\begin{array}{l}\text { Statewide with largest } \\
\text { acquisitions in Northern } \\
\text { Maine }\end{array}$ & $\begin{array}{l}\text { Land trusts conserving land in } \\
\text { south under fee and easement; } \\
\text { voluntary easements in the } \\
\text { North }\end{array}$ & $\begin{array}{l}\text { Lack of state and federal money } \\
\text { and increase in land values in } \\
\text { southern Maine leads to greatest } \\
\text { opportunities in Northern Maine; } \\
\text { under reserve model there is } \\
\text { increasing opportunity for carbon } \\
\text { easements }\end{array}$ \\
\hline
\end{tabular}


Maine Scenario Workshop 10.1615

New England Environmental Finance Center, University of Southern Maine, ME

\section{Scenario 4: Green Woodland}

Drivers: population and economic decline in response to climate change, combined with high valuing and innovative use of natural assets

\section{Storyline:}

- Population and economic decline (empty place), innovate impact use

- Woodland - chose this name after the town of Woodland, Maine which has a very new tissue plant but population is still declining.

- Theme - greater efficiency

- Population decline in rural areas accelerates

- Modest ag expansion

- No forest loss - perhaps expand into rural residential areas

PROS:

- Some of the pros are that land use is stabilized, not losing forest, so maintain ecosystem services

- Innovation advances makes the region highly competitive in global markets

- Innovation also leads to lower footprint per unit of product (greater efficiency)

CONS:

- Local economic opportunity declines

- Less opportunity for social mobility because of capitalization costs of businesses

- Societal decline, loss of rural communities/heritage

- Businesses concentrate because of capital costs

- More intensive land use, younger forests

- Over-reliance on natural resources

- Fundamental to that model is that less and less labor is needed over time (labor is replaced by technology)

- As a result it is a less attractive place to live -- people (kids) less and less likely to have opportunities over time - which puts communities, social basis at risk

- This undermines economic basis, as don't have a quality labor base to draw upon to maintain that innovative basis

- Economic (in)equality might become more of an issue

- There is a lot of forest but it is likely a younger forest 
Table A2.12. Scenario 4: Green Woodland

\begin{tabular}{|c|c|c|c|c|}
\hline Land use & How Much? & Where? & What kind? & Why? \\
\hline $\begin{array}{l}\text { Forest to } \\
\text { Development }\end{array}$ & $\begin{array}{l}\text { 0-400 acres/year } \\
\text { (more forest, less } \\
\text { development) }\end{array}$ & $\begin{array}{l}\text { In metro and regional } \\
\text { centers and to some } \\
\text { extent along major } \\
\text { arteries }\end{array}$ & $\begin{array}{l}\text { Residential, retail, and } \\
\text { commercial subdivision }\end{array}$ & $\begin{array}{l}\text { Continued concentration of population in } \\
\text { urban/regional areas and around } \\
\text { communication/transportation corridors better } \\
\text { and concentrated services, less economic } \\
\text { opportunities in rural areas }\end{array}$ \\
\hline $\begin{array}{l}\text { Forest to } \\
\text { Agriculture }\end{array}$ & 0 to 1000 acres/year & $\begin{array}{l}\text { Valleys, former ag } \\
\text { lands } \\
\text { Aroostock County, in } \\
\text { valleys }\end{array}$ & $\begin{array}{l}\text { Pastureland and some row } \\
\text { crops } \\
\text { Specialty ag products } \\
\text { Could be intensively } \\
\text { managed using technology } \\
\text { in all phases of production }\end{array}$ & $\begin{array}{l}\text { Conversion of "fallow" (former ag) land to } \\
\text { current farming } \\
\text { Some woodland owners convers to ag for } \$ \\
\text { Market for specialty ag } \\
\text { Landownerships could be concentrated in fewer } \\
\text { owners who have access to capital-intensive } \\
\text { production systems based on technology }\end{array}$ \\
\hline $\begin{array}{l}\text { Timber } \\
\text { Harvesting }\end{array}$ & 600,000 acres/year & $\begin{array}{l}\text { Northern and eastern } \\
\text { Maine }\end{array}$ & $\begin{array}{l}\text { Fiber and wood for value- } \\
\text { added products ((furniture } \\
\text { making for example) } \\
\text { Movement toward shorter } \\
\text { rotations and more highly } \\
\text { managed woodlands with } \\
\text { increased technology for } \\
\text { harvest/processing }\end{array}$ & $\begin{array}{l}\text { Increased global market for fiber. Innovation for } \\
\text { manufacture of value-added and specialty } \\
\text { products. Demand for wood fiber grows but } \\
\text { production becomes capital and technology } \\
\text { intensive. }\end{array}$ \\
\hline Conservation & $\begin{array}{l}\text { Fewer large parcels (a Nat } \\
\text { Park being the exception) } \\
\text { More local smaller places } \\
\sim 20,000 \text { acres/year } \\
\text { Rate may increase to } 2025 \\
\text { and then decrease to } 2060\end{array}$ & $\begin{array}{l}\text { Smaller parcels in } \\
\text { central and southern } \\
\text { Maine } \\
\text { A few larger parcels in } \\
\text { No. Maine (National } \\
\text { Park) }\end{array}$ & $\begin{array}{l}\text { Local places of interest } \\
\text { Places of special } \\
\text { ecological and habitat } \\
\text { significance } \\
\text { Waterways and shorelines }\end{array}$ & $\begin{array}{l}\text { Lower pop.; more need of ecosystem services } \\
\text { and the innovation to market these services to } \\
\text { other faster-growing places in the NE. However, } \\
\text { government support may dry up and decline by } \\
2060 \\
\text { due to low pop. That may be countered by } \\
\text { interest in the conservation of ecosystem } \\
\text { services by interests outside the state. }\end{array}$ \\
\hline
\end{tabular}




\section{Connecticut Scenario Workshop Summary}

October 22, 2015

Global Institute of Sustainable Forestry, Yale School of Forestry and Environmental Studies

People redistribute due to climate change

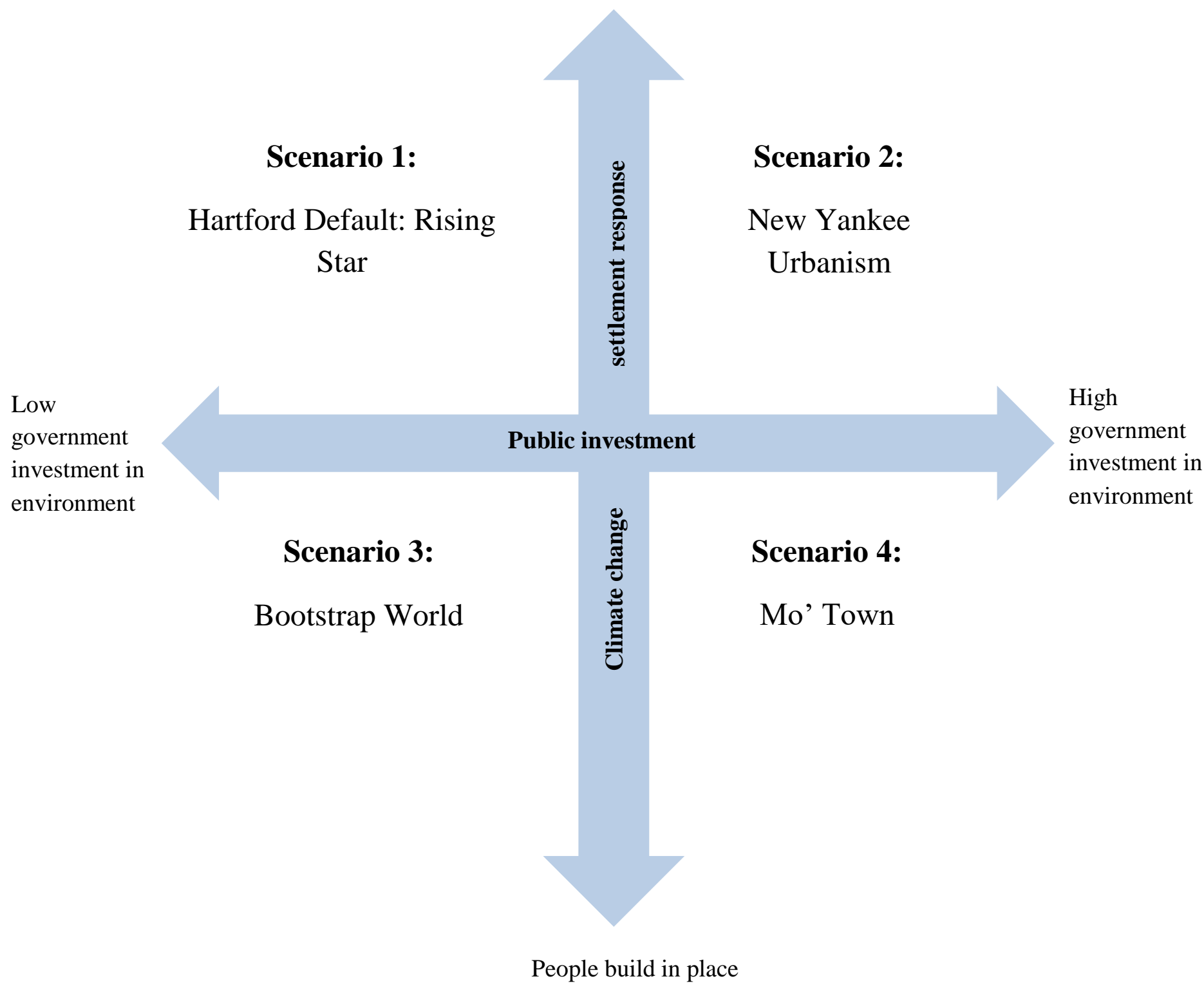

Fig. A2.4. Connecticut scenario matrix 


\section{Scenario 1. Hartford Default Rising Star}

Drivers: low government investment in environment, people redistribute due to climate change

\section{Storyline:}

- Decrease in government spending on the environment coupled with an increase in migration due to climate change.

- There is inland migration from coastal areas of CT and an influx of climate migrants from other parts of the world due to climate change because the state will likely not face the same detrimental effects of climate change as desert and tropical regions.

- Major east coast current metro centers (New York City and Boston) face inundation and decline

- Disrupted transportation corridors along shore I-91 metro north corridor shifts population and increases privatization on $\mathrm{N}-\mathrm{S}$ I 91.

PROS:

- Less fear of cities and more movement to Hartford and Springfield from other urban areas

- Hartford and Springfield become financial hubs

- More local culture

- More locally grown food to support population

- Conventional energy strategy + energy conservation

CONS:

- More food ghettos

- $\quad$ Energy = more burning of wood, trash - increased air pollution

- Climate change would result in human health issues

- Increased residential development and fragmentation - rising property values

- Fragmentation leaves few tracts of land to support profitable forestry

- Off the grid sprawl enabled by private solar - spectrum would increase in intensity due to pop. influx from NY/ Boston

- Loss of open space because of increases in land value from population influx

- More agriculture in once open spaces

- Economic segregation likely to continue

- Increased demand for land and lower government investment in conservation leads to a decline in land conservation 
Table A2.13. Scenario 1: Hartford Default Rising Star

\begin{tabular}{|c|c|c|c|c|}
\hline Land use & How Much? & Where? & What kind? & Why? \\
\hline $\begin{array}{l}\text { Forest to } \\
\text { Development }\end{array}$ & $\begin{array}{l}15-20 \% \text { increase } \\
\text { in annual rate of } \\
\text { development } \\
\text { from current } \\
\text { trend }\end{array}$ & $\begin{array}{l}\text { This development will occur most } \\
\text { notably along the central corridor of the } \\
\text { state and north of New Haven and within } \\
\text { and surrounding Hartford. However, the } \\
\text { urban sprawl will have rippling effects in } \\
\text { the more open western and eastern parts } \\
\text { of the state with unprotected forests } \\
\text { becoming largely perforated with } \\
\text { residential development. Also } \\
\text { development will continue to occur along } \\
\text { the coast but inland. As the sea level } \\
\text { rises significantly both in CT and in } \\
\text { surrounding states, the development } \\
\text { along the coast will begin to exhibit a } \\
\text { notable decline. }\end{array}$ & $\begin{array}{l}\text { This development will be } \\
\text { predominantly residential but also } \\
\text { include commercial buildings. As } \\
\text { migrants shift away from areas } \\
\text { affected by climate change there will } \\
\text { be continued development in higher } \\
\text { elevation regions to escape flooding } \\
\text { and sea level rise. Coastal and } \\
\text { lowland areas will become "climate } \\
\text { ghettos" where underserved } \\
\text { populations will experience "climate } \\
\text { injustices" from exposure to the } \\
\text { negative effects of climate change. }\end{array}$ & $\begin{array}{l}\text { Since migration from coastal } \\
\text { areas of CT to inland regions will } \\
\text { likely occur due to climate change } \\
\text { there will be increased pressures } \\
\text { for residential development in the } \\
\text { state. Also climate migrants from } \\
\text { around the U.S. and the world } \\
\text { may be driven to more temperate } \\
\text { climatic regions like CT. This will } \\
\text { happen because the state will } \\
\text { likely not face the same } \\
\text { detrimental effects of climate } \\
\text { change as desert and tropical } \\
\text { regions. }\end{array}$ \\
\hline $\begin{array}{l}\text { Forest to } \\
\text { Agriculture }\end{array}$ & $\begin{array}{l}5 \% \text { increase in } \\
\text { annual rate of } \\
\text { forest } \\
\text { conversion to } \\
\text { agriculture from } \\
\text { current trend }\end{array}$ & $\begin{array}{l}\text { Small farms will continue to appear } \\
\text { relatively ubiquitously across the state. } \\
\text { However, the Western and Eastern parts } \\
\text { of the state will likely see the greatest } \\
\text { increase in small farms to supply } \\
\text { demands for locally grown food. } \\
\text { Large farm fields in the CT River } \\
\text { floodplain may be affected by climate } \\
\text { change induced flooding or conversion to } \\
\text { development. Even with this loss of ag } \\
\text { land, we still see the total acreage in ag } \\
\text { production increasing including urban } \\
\text { and suburban ag. }\end{array}$ & $\begin{array}{l}\text { The agriculture will not likely be } \\
\text { industrial scale agriculture. Most } \\
\text { agriculture efforts will be carried out } \\
\text { through small scale operations of } 25 \\
\text { acres or less. Most farming will be } \\
\text { for locally grown produce however } \\
\text { some livestock farming will also } \\
\text { occur. }\end{array}$ & $\begin{array}{l}\text { Pressures to provide locally } \\
\text { grown food will help to drive a } \\
\text { slight increase in CT agriculture } \\
\text { however these new operations } \\
\text { will likely be small in scale. Also } \\
\text { pressures to feed an increasing } \\
\text { population in the state and across } \\
\text { the earth will also contribute to a } \\
\text { slight increase in agriculture in } \\
\text { the state. }\end{array}$ \\
\hline
\end{tabular}


Connecticut Scenario Workshop 10.22.15

Yale School of Forestry and Environmental Studies

\begin{tabular}{|c|c|c|c|c|}
\hline $\begin{array}{l}\text { Timber } \\
\text { Harvesting }\end{array}$ & $\begin{array}{l}\text { Rate of timber } \\
\text { harvesting per } \\
\text { year has no } \\
\text { significant } \\
\text { increase or } \\
\text { decrease. }\end{array}$ & $\begin{array}{l}\text { NW of CT will still have notable forest } \\
\text { tracts such as Great Mountain forest that } \\
\text { can be harvested for timber. The large } \\
\text { remaining forest tracts that were } \\
\text { preserved many years ago will continue } \\
\text { to be harvested of timber. No notable } \\
\text { expansion of timber harvesting } \\
\text { operations will likely occur in the state. }\end{array}$ & $\begin{array}{l}\text { Timber will be used for a variety of } \\
\text { products such as paper, wood } \\
\text { products, Christmas trees, and } \\
\text { firewood. Large timber industries } \\
\text { will likely continue to prefer states } \\
\text { with larger tracts of land in the } \\
\text { northernmost state of the United } \\
\text { States. }\end{array}$ & $\begin{array}{l}\text { Since almost all large forest tracts } \\
\text { have been fragmented there are } \\
\text { very few tracts left that can be } \\
\text { profitably harvested in CT. A few } \\
\text { remaining large tracts will } \\
\text { continue to be harvested. The } \\
\text { value of land for development } \\
\text { will continue to increase making } \\
\text { development a more profitable } \\
\text { action for landowners. }\end{array}$ \\
\hline Conservation & $\begin{array}{l}\text { Decline } 5 \% \text { in } \\
\text { annual } 1 \text { acres } \\
\text { conserved } \\
\text { from current } \\
\text { trend }\end{array}$ & $\begin{array}{l}\text { This development will occur most } \\
\text { notably along the central corridor of the } \\
\text { state and north of New Haven and within } \\
\text { and surrounding Hartford. However, the } \\
\text { urban sprawl will have rippling effects in } \\
\text { the more open western and eastern parts } \\
\text { of the state with unprotected forests } \\
\text { becoming largely perforated with } \\
\text { residential development. Also } \\
\text { development will continue to occur along } \\
\text { the coast but inland. As the sea level } \\
\text { rises significantly both in CT and in } \\
\text { surrounding states, the development } \\
\text { along the coast will begin to exhibit a } \\
\text { notable decline. }\end{array}$ & $\begin{array}{l}\text { Conservation will occur on } \\
\text { parcels of significantly decreased } \\
\text { size. As larger tracts continue to } \\
\text { be divided amongst property } \\
\text { owners and the population of CT } \\
\text { continues to increase due to } \\
\text { climate refugees and inland } \\
\text { migration from coastal } \\
\text { communities the difficulties } \\
\text { associated with preserving } \\
\text { contiguous tracts will increase. }\end{array}$ & $\begin{array}{l}\text { CT lands will continue to } \\
\text { exhibit fragmenting "hard" } \\
\text { development that will make } \\
\text { conservation of large parcels } \\
\text { increasingly difficult. Also real } \\
\text { estate in Connecticut in the } \\
\text { inland regions will become } \\
\text { increasingly valuable due to its } \\
\text { proximity to NYC and Boston. } \\
\text { Additionally coastal } \\
\text { communities in CT will } \\
\text { migrate inland due to sea level } \\
\text { rise causing increased pressure } \\
\text { on developing the more inland } \\
\text { areas of CT. Declining } \\
\text { government expenditures in } \\
\text { open space protection results } \\
\text { in significant reductions in } \\
\text { numbers of conserved acres } \\
\text { per year. }\end{array}$ \\
\hline
\end{tabular}




\section{Scenario 2: New Yankee Urbanism}

Drivers: high government investment in environment and people redistribute due to climate change

\section{Storyline:}

- People redistribute due to climate change and there is high government investment in the environment (including environmental systems)

- There is redistribution from drought stricken west and coastal areas as well as flood prone riverine areas

- This leads to increase in population in the state and an increase in density in urban areas.

- With government investment there are vibrant urban centers and focus on smart growth with a remaining tree canopy wherever possible

- As a result, the increased population is accommodated in large but not total part by infill development.

- There is also as much conservation of open land as possible.

PROS:

- Diverse, vibrant urban centers

- Less pressure on inner-lands $\rightarrow$ buying or protecting open space easier

- Development would move out of floodplains leaving all of those areas to be reclaimed as open space and for ecosystem services

- Increase in ag expectations given the increased population and growing interest in greater self-reliance

- Adequate resources to invest in forest health

- Interest in increasing renewable energy, including biomass

- Public resources supports increased investment in conservation for climate adaptation and mitigation (conserve flood plains, sequester carbon) and support recreational use

CONS:

- Have to produce more food if people from the west move here.

- Where would the ag. go?

- Fewer opportunities for living south (of something)? Not sure what this means/

- Potential for gentrification

- Potential for loss of connection with nature

- (Community design could limit these negative impacts) 
Connecticut Scenario Workshop 10.22.15

Yale School of Forestry and Environmental Studies

Table A2.14. Scenario 2: New Yankee Urbanism

\begin{tabular}{|c|c|c|c|c|}
\hline Land change & How Much? & Where? & What kind? & Why? \\
\hline $\begin{array}{l}\text { Forest to } \\
\text { Development }\end{array}$ & $\begin{array}{l}\text { No net loss in forest cover } \\
\text { overall and a net gain is } \\
\text { possible... } \\
25 \% \text { of suburban forests is } \\
\text { lost to high-density } \\
\text { development } \\
\text { floodplains are recovered } \\
\text { and } 50 \% \text { converted back to } \\
\text { forest } \\
50 \% \text { of brownfields are } \\
\text { restored as forests } \\
\text { Urban tree cover is increased }\end{array}$ & & & $\begin{array}{l}\text { High gov't investment in conservation } \\
\text { emphasizes smart growth, which includes } \\
\text { the addition of trees where possible, } \\
\text { especially in already developed areas, } \\
\text { where urban forests have a long way to go } \\
\text { before their potential is reached. } \\
\text { Some suburban forests are sacrificed to } \\
\text { increase housing density to take pressure } \\
\text { off hinterlands. }\end{array}$ \\
\hline $\begin{array}{l}\text { Forest to } \\
\text { Agriculture }\end{array}$ & $\begin{array}{l}50 \% \text { increase in total } \\
\text { agriculture, coming from } \\
\text { suburban, exurban forests } \\
50 \% \text { of Floodplains } \\
\text { converted to sustainable } \\
\text { agriculture } \\
\text { Some exurban forests are } \\
\text { converted to pasture } \\
\text { agriculture. } \\
\text { Big increase in } \\
\text { urban/suburban ag (this } \\
\text { statement does not relate to } \\
\text { forest conversion except that } \\
\text { it is a reason why we did not } \\
\text { dedicate more forested land } \\
\text { to ag in what we forsee could }\end{array}$ & & $\begin{array}{l}\text {...for high quality veggies } \\
\text {...for hardier crops, silage, } \\
\text { and pasture for dairy farms }\end{array}$ & $\begin{array}{l}\text { More mouths to feed in CT from climate } \\
\text { redistribution } \\
\text { Increased regional self-reliance for } \\
\text { sustainability purposes }\end{array}$ \\
\hline
\end{tabular}


Connecticut Scenario Workshop 10.22.15

Yale School of Forestry and Environmental Studies

\begin{tabular}{|c|c|c|c|c|}
\hline & $\begin{array}{l}\text { be similar to the "regional } \\
\text { self-reliance" scenario) }\end{array}$ & & & \\
\hline 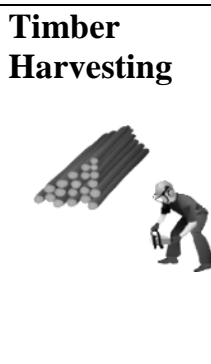 & $\begin{array}{l}2 \mathrm{x} \text { today's harvest rate } \\
\text { Focus on sustainable } \\
\text { working forests }\end{array}$ & $\begin{array}{l}\text {... across the entire state, } \\
\text { but mostly from } \\
\text { hinterlands }\end{array}$ & $\begin{array}{l}\text { Timber and Non-timber } \\
\text { forest products }\end{array}$ & $\begin{array}{l}\text { Use revenue to put back into } \\
\text { environment/conservation } \\
\text { Forest management to improve forest } \\
\text { health and diversity } \\
\text { Increased focus on alternative energy } \\
\text { compatible with sustainable biomass } \\
\text { energy production. }\end{array}$ \\
\hline Conservation & $\begin{array}{l}\text { Protect all state significant } \\
\text { and highest productivity } \\
\text { agricultural soils. } \\
\text { Protect } 75 \% \text { of intact forests } \\
\text { (i.e., any patch of forest } \\
\text { currently greater than } 50 \\
\text { acres) } \\
\text { Protect all floodplains and } \\
\text { riparian zones, including } \\
\text { reclaiming them (see other } \\
\text { conversions for more info). }\end{array}$ & $\begin{array}{l}\text { Big focus would probably } \\
\text { be Northwest hills and the } \\
\text { Last Green Valley Service } \\
\text { area, as well as along all } \\
\text { river corridors (CT River, } \\
\text { Thames, etc.) }\end{array}$ & $\begin{array}{l}\text { Use agricultural easements } \\
\text { to take highest and best use } \\
\text { (HBU) pressure off } \\
\text { productive ag lands. } \\
\text { Use working forest } \\
\text { easements to take HBU } \\
\text { pressure off rural forest } \\
\text { Purchase or use easements } \\
\text { on floodplains/riparian } \\
\text { areas and combine with } \\
\text { recreational initiatives, and } \\
\text { habitat corridor restoration. }\end{array}$ & $\begin{array}{l}\text {...for healthy development of soil } \\
\text {...for watershed health, climate change } \\
\text { and flood mitigation } \\
\text {...for a climate resilient landscape, human } \\
\text { health, biodiversity protection, recreational } \\
\text { usage }\end{array}$ \\
\hline
\end{tabular}




\section{Scenario 3: Bootstrap World}

Drivers: low government investment in environment and people build in place

\section{Storyline:}

- Staying in place as staying in $\mathrm{CT}$ as the climate changes

- Lot of shifts at local and state levels - waterfront properties $\rightarrow$ less valuable, hilltops more so

- Coastal areas are less valuable, inland areas more valuable

- Wealth redistribution results in population redistribution (poorer in areas prone to flooding and impact)

- Midland areas become more valuable for local agriculture - Demand for local produce increases as supply of produce from CA and the southwest decreases due to drought conditions.

- Tension between places to live and food supply

- There's a huge difference between rich and poor

- Increased demand for biofuel as cost of traditional sources of energy and heat rises

- Climate change infrastructure - deep water ports, etc. would be protected in some way

- Any of limited investment would be in grey infrastructure to protect against sea level rise, but not much money to do so.

PROS:

- More of a community focus based on need.

- Nonprofit corporation partnerships.

- Corporations would start stepping up more into public sector with little to no government investors - need educated and healthy workers that have places to live!

- New development is related to migration away from the coastal corridor - both commercial and residential

- Cluster development (open space or conservation development) becomes more accepted in rural communities not due to regulation as much as necessity

CONS:

- Economic inequity is significant

- Without gov't investments and not looking at the long term, local community focuses inward, resulting in short-term perspectives and planning

- Quality of life decreases, infrastructure fails, waste water treatment fails

- What happens with public lands?

- As government shrinks investments in open space will decline

- What happens to privately conserved lands? 
Connecticut Scenario Workshop 10.22.15

Yale School of Forestry and Environmental Studies

Table A2.15. Scenario 3: Bootstrap World

\begin{tabular}{|c|c|c|c|c|}
\hline Land change & How Much? & Where? & What kind? & Why? \\
\hline $\begin{array}{l}\text { Forest to } \\
\text { Development }\end{array}$ & $\begin{array}{l}\text { About the } \\
\text { same as } \\
\text { current }\end{array}$ & $\begin{array}{l}\text { Undeveloped areas } \\
\text { north of i-95 Corridor- } \\
\text { fill in of suburban, large } \\
\text { lot residential areas. } \\
\text { Inland cities (Hartford, } \\
\text { Waterbury, Norwich, } \\
\text { New Britain) }\end{array}$ & $\begin{array}{l}\text { Small single family } \\
\text { homes (no more } \\
\text { McMansions). } \\
\text { Multi-family } \\
\text { dwellings. Cluster } \\
\text { development (open } \\
\text { space development, } \\
\text { conservation } \\
\text { development). Co- } \\
\text { housing. }\end{array}$ & $\begin{array}{l}\text { - New development is related to migration away from the coastal } \\
\text { corridor - both commercial and residential. } \\
\text { - Cluster development (open space or conservation development) } \\
\text { becomes more accepted in rural communities. } \\
\text { As density increases municipal zoning begins to shift to smaller lot } \\
\text { sizes. }\end{array}$ \\
\hline $\begin{array}{l}\text { Forest to } \\
\text { Agriculture }\end{array}$ & $\sim 0$ new acres & $\begin{array}{l}\text { Dairy, tobacco and } \\
\text { fallow ag lands convert } \\
\text { to truck farms } \\
\text { (diversified vegetable } \\
\text { and fruit crops). }\end{array}$ & $\begin{array}{l}\text { Diversified } \\
\text { vegetable/fruit } \\
\text { crops. }\end{array}$ & $\begin{array}{l}\text { - Demand for local produce increases as supply of produce from CA } \\
\text { and the southwest decreases due to drought conditions. } \\
\text { - As food prices increase agriculture becomes more economically } \\
\text { viable in state although energy prices continue to limit profitability. } \\
\text { - Increase in diverse crop farms (truck farms), decrease in dairy and } \\
\text { tobacco. So conversion is dairy and tobacco to truck farms. } \\
\text { - More food produced in greenhouses using biofuel for energy. }\end{array}$ \\
\hline $\begin{array}{l}\text { Timber } \\
\text { Harvesting }\end{array}$ & $\begin{array}{l}18,000 \\
\text { acres/year }\end{array}$ & $\begin{array}{l}\text { Primarily Northeast } \\
\text { corner of state and } \\
\text { Water Company lands } \\
\text { (MDC and RWA). }\end{array}$ & $\begin{array}{l}\text { Chordwood } \\
\text { High Value Timber }\end{array}$ & $\begin{array}{l}\text { Increased demand for biofuel as cost of traditional sources of energy and } \\
\text { heat rises } \\
\text { Timber value increases as forest matures - private owners look to extract } \$ \$ \\
\text { from holdings }\end{array}$ \\
\hline Conservation & $\begin{array}{l}250 \\
\text { acres/year }\end{array}$ & $\begin{array}{l}\text { Very local and } \\
\text { opportunistic, mostly in } \\
\text { wealthy communities } \\
\text { that have a more robust } \\
\text { tax base }- \text { e.g. Fairfield } \\
\text { county }\end{array}$ & & $\begin{array}{l}\text { - State of CT will soon reach its goal of conserving } 21 \% \text { of its land } \\
\text { mass (state is currently at around } 18 \% \text { ) } \\
\text { - As government shrinks investments in open space will decline } \\
\text { As state and municipal budgets are squeezed they will seek } \\
\text { additional tax revenues by doing away with tax incentives for } \\
\text { conservation }\end{array}$ \\
\hline
\end{tabular}




\section{Scenario 4: Mo’'Town}

Drivers: people build in place (for CC response) and high government investment in the environment

\section{Storyline:}

- In a case where CT not suffering as hard from major catastrophies driven by climate change $\rightarrow$ Gov't funding more money

- More people going into CT are not going to relocate.

- There is some forced migration from western U.S.

- In this scenario we can see sea large tide gates, sea walls, hardened infrastructure, spending $\$ \$$ to resist sea level rise and climate change and related issues

- Would need good infrastructure

- With lots of $\$$ we could see big push in energy and tech innovation

- Big cheap energy advancements.

- Odd solutions like gigantic greenhouses to support ag needs, fast transportation and major city system

- Would see very large city centers, taller buildings, more rural areas and opportunities for open areas

- Investments in cities bring people in

CONS:

- Run risk of high poverty

- Social stratification

- Increase in taxes and public debt! How are you going to deal with that.

- Dependency on complicated technological systems with potential for failures

PROS:

- Huge gains in energy, tech, open space

- Government investments will protect citizens from sea level change

- Government investment supports increased land acquisition for open space

- Subsidies for food production 
Connecticut Scenario Workshop 10.22.15

Yale School of Forestry and Environmental Studies

Table A2.16. Scenario 4: Mo’ Town

\begin{tabular}{|c|c|c|c|c|}
\hline Land change & How Much? & Where? & What kind? & Why? \\
\hline $\begin{array}{l}\text { Forest to } \\
\text { Development }\end{array}$ & $\begin{array}{l}\text { Less than current } \\
\text { trends. } \sim 1000- \\
2000 \text { acre/year? }\end{array}$ & $\begin{array}{l}\text { Primarily on the fringes } \\
\text { of developed urban } \\
\text { centers, leveraging } \\
\text { existing transportation } \\
\text { and other } \\
\text { infrastructure. }\end{array}$ & $\begin{array}{l}\text { High intensity where existing } \\
\text { infrastructure exists. } \\
\text { Residential and commercial } \\
\text { will occur together. The } \\
\text { suburban sprawl will slow } \\
\text { down. New development will } \\
\text { occur on the fringe of urban } \\
\text { centers, offsetting loss of } \\
\text { coastal lands to sea-level rise. }\end{array}$ & $\begin{array}{l}\text { Given a scenario where emphasis of development } \\
\text { occurs in already developed areas and building up } \\
\text { metropolitan centers and moving away from } \\
\text { suburbs, one would suspect a decrease in overall } \\
\text { development trends into forested areas. We also } \\
\text { agreed that we suspect a decreased population with } \\
\text { an increased senior population. }\end{array}$ \\
\hline $\begin{array}{l}\text { Forest to } \\
\text { Agriculture }\end{array}$ & 150 acres/ year & Rural areas. & $\begin{array}{l}\text { Greenhouse productions could } \\
\text { be more likely given improved } \\
\text { access to energy resources. }\end{array}$ & $\begin{array}{l}\text { Existing forests in CT do not have high quality } \\
\text { soils. However given cheaper access to energy and } \\
\text { Government investment, access to fertilizer and } \\
\text { improved farming methods could incentivize } \\
\text { farming in the region. } \\
\text { A small increase in existing trends is suspected. }\end{array}$ \\
\hline $\begin{array}{l}\text { Timber } \\
\text { Harvesting }\end{array}$ & $\begin{array}{l}30,000 \text { acres a } \\
\text { year. }\end{array}$ & $\begin{array}{l}\text { Northeast and } \\
\text { Northwest CT? }\end{array}$ & $?$ & $\begin{array}{l}\text { CT will continue to have high quality woods, and } \\
\text { current forestry is not tapping into the full potential } \\
\text { of sustainable timber harvesting. }\end{array}$ \\
\hline Conservation & $\begin{array}{l}5000 \text { acres per } \\
\text { year }\end{array}$ & $\begin{array}{l}\text { Rural, vacant } \\
\text { residential properties. }\end{array}$ & $\begin{array}{l}\text { Depending on how the } \\
\text { government distributes the } \\
\text { money, this could be federal } \\
\text { state, municipal or some other } \\
\text { owned land. Although in our } \\
\text { initial example we imagined } \\
\text { federal owned open space, } \\
\text { purchasing once was } \\
\text { residential properties. }\end{array}$ & $\begin{array}{l}\text { Land value will decrease in rural areas as a result of } \\
\text { the centralized urban development. } \\
\text { Home foreclosures during an economic downturn } \\
\text { would also allow for more land grabs. } \\
\text { The government investment will also provide } \\
\text { incentives for people to live in these population } \\
\text { hubs. }\end{array}$ \\
\hline
\end{tabular}




\section{Rhode Island Scenario Workshop Summary}

November 4, 2015

November 4, 2015 Whispering Pines Conference Center

Strong land stewardship ethic

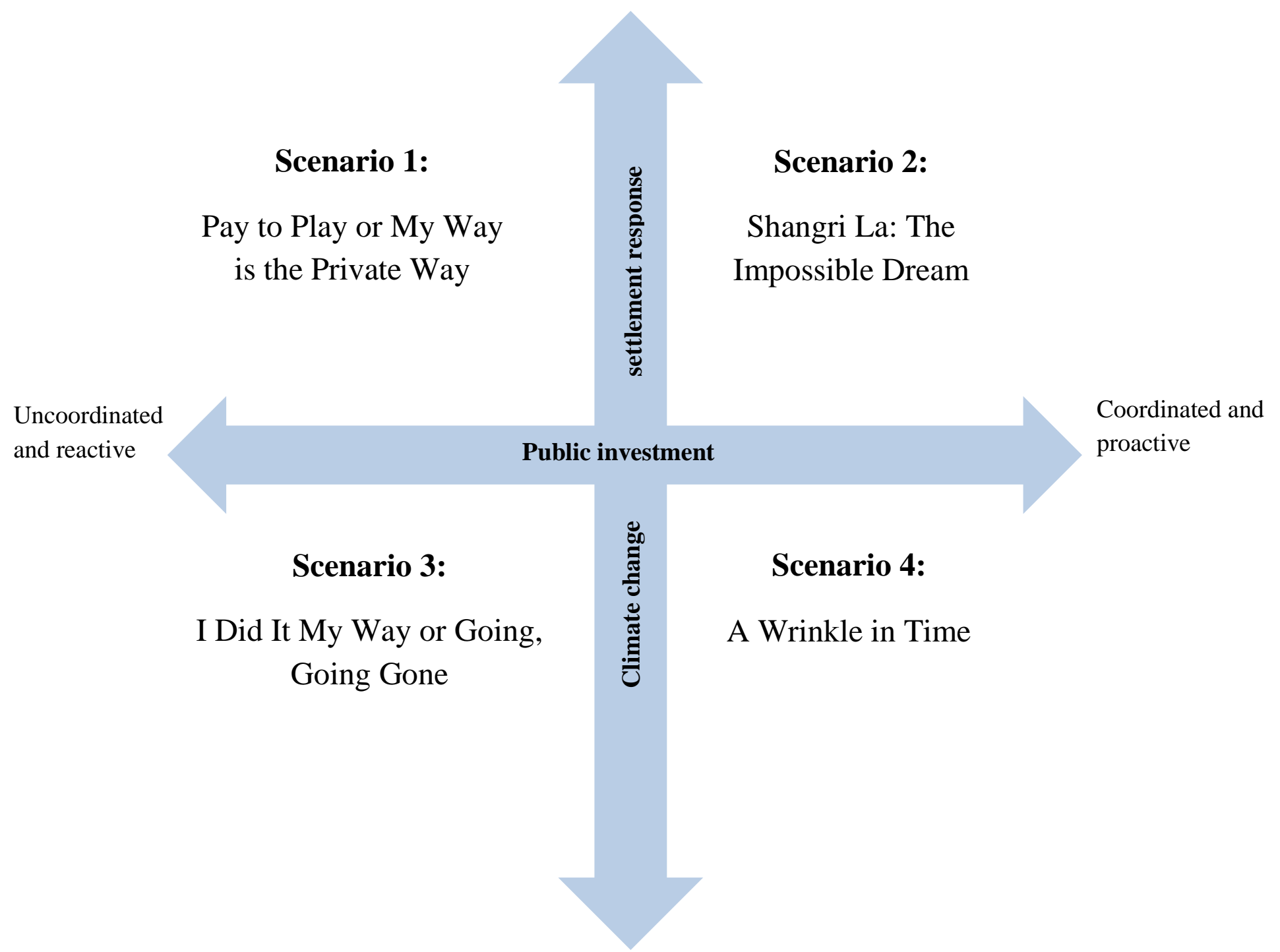

Weak land stewardship ethic

Fig. A2.5. Rhode Island scenario matrix 
Rhode Island Scenario Workshop, 11.4.15

Whispering Pines Conference Center, University Of Rhode Island

\section{Scenario 1: 'Pay to play' or 'My way is the private way'}

Drivers: strong land stewardship ethic, uncoordinated government

Storyline:

- Privately funded innovation without government support is a feature of this approach. fshoots

$\bullet$

- Strong, very engaged NGOs,

- Ecosystem services become the framework for land conservation.

- Zero investment in transportation, but people's cars would become more efficient, etc.

- By 2060, all land in the state would either be conserved or developed, and would now be in a process of a reclaiming land for more development.

- Awareness and engagement was high, which was an outcome, due to work by private and public non-profit, working at having people understanding the benefits - engagement people from a young age, etc. That would be how we got to the point of having a strong stewardship ethic.

- The state population is stable. Lots of outside the state landowners, and visitors.

- No coordinated response to climate change. Somewhat of a free for all.

PROS:

- Lots of value-based partnerships generated as a result of lack of government involvement, so groups around RI have incentives to work together.

- Strong land-stewardship ethic, but only $5-10 \%$ of population has access to land

- High engagement in local economy by private citizens

- High energy costs may drive efficient transportation and energy sectors

- The conditions foster a 'creative' economy - forces working on it rather than largely STEM economy that is, for example, already developed in Boston.

- Public perception for conservation land is good, but not a lot of public access.

CONS:

- Lack of socio-economic diversity and most disproportionate impacts to disenfranchised.

- Lack of access to protected land, most land is privately protected

- More income disparity

- No coordinated public response to climate change. Private landowners left to deal on their own with their own property, problems etc. Lots of climate change losers.

- High energy costs

- Under-utilized and underfunded public land and spaces

- More sprawl, more McMansions in the woods, pressure to develop more remote area. 
Rhode Island Scenario Workshop, 11.4.15

Whispering Pines Conference Center, University Of Rhode Island

Table A2.17. Scenario 1: Pay to Play

\begin{tabular}{|c|c|c|c|c|}
\hline Land use & How Much? & Where? & What kind? & Why? \\
\hline $\begin{array}{l}\text { Forest to } \\
\text { Development }\end{array}$ & Similar trend to what has been occurring & $\begin{array}{l}\text { Desirable rural location } \\
\rightarrow \text { coastal, scenic } \\
\text { viewsheds }\end{array}$ & McMansions in the woods & $\begin{array}{l}\text { McMansions in the woods, } \\
\text { limited control to direct } \\
\text { growth = sprawl } \\
\text { Increased residential } \\
\text { development in desirable } \\
\text { rural areas (remote) }\end{array}$ \\
\hline $\begin{array}{l}\text { Forest to } \\
\text { Agriculture }\end{array}$ & $\begin{array}{l}\text { Very little } \\
\text { Similar to current trend }\end{array}$ & $\begin{array}{l}\text { Suburban ring } \\
\text {-Not in rural or urban } \\
\text { areas } \rightarrow \text { in these areas } \\
\text { ag will increase through } \\
\text { other means }\end{array}$ & $\begin{array}{l}\text {-Mostly redevelopment of urban } \\
\text { areas into farmland } \\
\text {-Reclamation of fallow land } \\
\text { Some reclamation of young } \\
\text { forests } \\
\text { - Gentlemen farming } \\
\text { - Value-added farm } \\
\quad \text { enterprises }\end{array}$ & $\begin{array}{l}\text { Increase local food } \\
\text { economy, but trend to } \\
\text { redevelop or reclaim } \\
\text { residential or urban or fallow } \\
\text { ag land. }\end{array}$ \\
\hline Timber Harvesting & A lot $\rightarrow 5 \mathrm{Xs}$ current rate & $\begin{array}{l}\text {-Private managed lands } \\
\text { (for biomass and forest } \\
\text { health) } \\
\text {-Public lands in an } \\
\text { unmanaged fashion (for } \\
\text { biomass) }\end{array}$ & $\begin{array}{l}\text {-Increased harvest for biomass } \\
\text {-Increased forest management } \\
\text { on private lands (but not state } \\
\text { land) } \\
\text {-Potential energy poaching on } \\
\text { public land, increased pests and } \\
\text { decreased forest health }\end{array}$ & $\begin{array}{l}\text {-Increased energy pricing } \\
\text {-Increased land stewardship } \\
\text { /forest management on } \\
\text { private land }\end{array}$ \\
\hline Conservation & $\begin{array}{l}\text { Total number of acres protected } \\
\text { Pace is steady until no available land left to } \\
\text { protect (interest increases, funds decrease). }\end{array}$ & $\begin{array}{l}\text {-Unmanaged public } \\
\text { lands } \\
\text { more affluent } \\
\text { communities } \\
\text {-Coastal, rural, urban } \\
\text { areas }\end{array}$ & $\begin{array}{l}\text {-Primarily private conservation } \\
\text { easements } \\
\text {-Increased fire risk on } \\
\text { conserved lands }\end{array}$ & $\begin{array}{l}\text { Strong engaged private land } \\
\text { trusts and NGOs drive } \\
\text { conservation. }\end{array}$ \\
\hline
\end{tabular}


Rhode Island Scenario Workshop, 11.4.15

Whispering Pines Conference Center, University Of Rhode Island

\section{Group B: 'Shangri la - the impossible dream'}

Drivers: strong land stewardship ethic, (LSE) and very coordinated government structure.

Storyline

- This is a pretty good combination, assuming that the government isn't all controlling - and is coordinated in the right way.

- Stable population growth, because of government incentives and polices concerning smart growth

- Housing that was available and affordable, but the whole cultural composition of our population would be diverse, with a lot of people living in the urban and village centers, due to the smart growth polices of coordinated government's polices - resulting in a good balance of conserved land and protected natural resources, as well as working forest and farm landscapes, and village centers.

- Plenty of farms and farm lots. And because of this strong land stewardship ethic, population is well educated and engaged and there is strong demand for local produce - so that $50 \%$ of consumption comes from local growth

- Coordinated energy structure due to government policies: a lot of the energy is in renewable resources.

- There has been adequate funding of the stewardship and environmental agencies to protect and enforce the environment laws, that the engaged and informed public with strong stewardship ethic leads to support of private land, and lots of volunteers that go out and battle invasive plants, support need to control deer population, etc.

- Lot of outdoor recreation opportunities while still protecting the quality of the water, etc.

- Strong coordinated government that also knows when to step out of the way of strong, engaged citizens. Government does what needs to be done and does not control everything but facilitates things.

- Climate change- coordinated government is able to rise to this challenge, steer development away from the coast, respond proactively, etc.

PROS: All pros!

CONS:

- If the government does overstep and becomes too strong, too proactive at that scale, there could be some negative results including pushback from well-educated public that doesn't want so much government

- If this scenario is too desirable, people want to come in (immigrate) all the time

- Another comment from a different group - may be a bit like Scandinavia? (High cost of living, people wanting to move there......) 
Rhode Island Scenario Workshop, 11.4.15

Whispering Pines Conference Center, University Of Rhode Island

Table A2.18. Scenario 2: Shangri la: the impossible dream

\begin{tabular}{|c|c|c|c|c|}
\hline Land use & How Much? & Where? & What kind? & Why? \\
\hline $\begin{array}{l}\text { Forest to } \\
\text { Development }\end{array}$ & Average/year $=50 \%$ of current rate & $\begin{array}{l}\text { Around town centers } \\
\text { in clusters }\end{array}$ & $\begin{array}{l}\text { Infill re-development } \\
\text { Residential } \\
\text { Senior-case and housing } \\
\text { Energy development }\end{array}$ & $\begin{array}{l}\text { Smart-growth and steered } \\
\text { development into population } \\
\text { centers }\end{array}$ \\
\hline $\begin{array}{l}\text { Forest to } \\
\text { Agriculture }\end{array}$ & 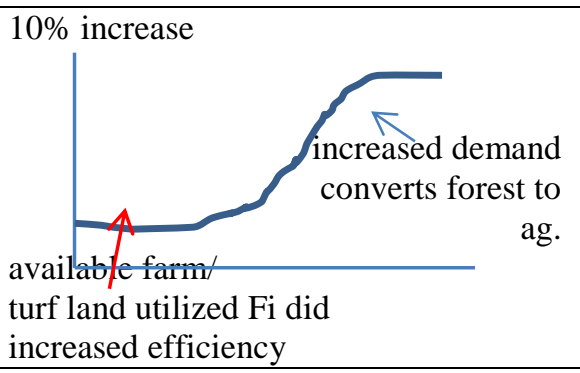 & $\begin{array}{l}\text { New plots and } \\
\text { expanded existing } \\
\text { farms near towns. } \\
\text { State and NGO lands } \\
\text { leased to farmers. }\end{array}$ & $\begin{array}{l}\text { Pasture/Hay } \\
\text { River bottom land to row crops } \\
\text { Orchards }\end{array}$ & $\begin{array}{l}\text { Locavores drive increase in } \\
\text { local food production. }\end{array}$ \\
\hline Timber Harvesting & $\begin{array}{l}\text { increase of harvests } \\
2 \% \rightarrow 5 \% \text { over time } \\
5 \% \text { of acreage/year thinning }\end{array}$ & $\begin{array}{cl}\text { Suburban and rural } \\
\text { - } & \text { private } \\
& \text { landowners } \\
\text { - } & \text { state lands } \\
\text { - } & \text { Land trusts }\end{array}$ & $\begin{array}{l}\text { Sustainable harvest due to } \\
\text { increased stewardship } \\
\text { Some high grading occurs } \\
\bullet \quad \text { increase in White Pine } \\
\text { • Decline in oak } \\
\text { Increase in Black Birch and Red } \\
\text { Maple }\end{array}$ & $\begin{array}{l}\text { Increase demand for local } \\
\text { wood products } \\
\text { Increase value of the timber } \\
\text { Gov't incentives to improve } \\
\text { forest health and carbon } \\
\text { sequestration } \\
\text { Gov't tax policies }\end{array}$ \\
\hline Conservation & $\begin{array}{l}\text { Some increase in protection once } \\
\text { increase in funding occurs }\end{array}$ & $\begin{array}{l}\text { High value cropland } \\
\text { in and around Bay } \\
\text { Expansion of existing } \\
\text { management areas }\end{array}$ & $\begin{array}{l}\text { Conservation easements for } \\
\text { agriculture land } \\
\text { Expansion of state management } \\
\text { areas }\end{array}$ & $\begin{array}{l}\text { Increased land prices, } \\
\text { competition for uses. } \\
\text { Increased government } \\
\text { incentives }\end{array}$ \\
\hline
\end{tabular}


Rhode Island Scenario Workshop, 11.4.15

Whispering Pines Conference Center, University Of Rhode Island

\section{Group 3: 'I did it my way' (Going, Going, Gone)}

Drivers: uncoordinated government, weak land stewardship ethic

\section{Storyline:}

- Self-interest rules, there are many roads and also ghost towns

- State agencies disappeared due to lack of funding

- Unless there is concern about water quality, there's no land conservation. People do not see natural resources as valuable. Sand and gravel are major resource industry.

- A 2060 land use map that is $20 \%$ open space, 50\% residential, 5\% industry (sand, gravel - but $30 \%$ ) of the economy, and $25 \%$ retail

- Where folks do not see natural resources as valuable and do not recognize these are critical part of the economy

- 'Road state' - changed the license plate from 'Ocean state'

- The mall of New England constructed in 2050. Charleston is still green, but much smaller due to sea level rise, Exeter is completely built out.

- Each municipality is doing its own thing. There are 39 different forest and water control boards. And there are no land use controls

- Absolutely no local food production, bring in food on great roads from CT

- AAA pays for 3 comfort stations local highways because drivers are not using I-95 because of the toll

PROS:

- Really good roads and bridges, which is something we've been lacking. More tax revenue for bigger municipal government.

- Strong industry in sand and gravel.

- Providing cheaper energy but depleting our resources.

- Sand and gravel are a major part of the economy

CONS:

- No local food production

- Increased disparity in income. Land ownership, only in a few private individuals

- Absentee ownership - lots of land owned from people overseas.

- Natural resource depletion 
Rhode Island Scenario Workshop, 11.4.15

Whispering Pines Conference Center, University Of Rhode Island

Table A2.19. Scenario 3: I Did It My Way

\begin{tabular}{|c|c|c|c|c|}
\hline Land use & How Much? & Where? & What kind? & Why? \\
\hline $\begin{array}{l}\text { Forest to } \\
\text { Development }\end{array}$ & $\begin{array}{l}1,200-1,800 / \text { year ( } 3 \text { times } \\
\text { recent trends) }\end{array}$ & $\begin{array}{l}\text { Outside current urban growth } \\
\text { boundaries }\end{array}$ & $\begin{array}{l}\text { Low density sprawl } \\
\text { and commercial } \\
\text { development }\end{array}$ & $\begin{array}{l}\text { No incentives for conservation (tax, } \\
\text { other) drive forest conversion to } \\
\text { more developed land uses. } \\
\text { Expansion of urban services } \\
\text { boundaries. }\end{array}$ \\
\hline $\begin{array}{l}\text { Forest to } \\
\text { Agriculture }\end{array}$ & $\begin{array}{l}1,000 \text { acres in } 10 \text { years }(90 \%) \\
\text { reduction }\end{array}$ & $\begin{array}{l}\text { Concentration into larger farms } \\
\text { away from urban core }\end{array}$ & $\begin{array}{l}\text { Expansion of existing } \\
\text { farms, urban farms and } \\
\text { garden plots }\end{array}$ & $\begin{array}{l}\text { Lack of stewardship ethic } \\
\text { diminishes importance of local food } \\
\text { supply and agriculture. Land ethic } \\
\text { encourages land consumption not } \\
\text { for long term-sustainability. }\end{array}$ \\
\hline $\begin{array}{l}\text { Timber } \\
\text { Harvesting }\end{array}$ & $7 \%$ per year & Suburban and rural towns & hi-grading & $\begin{array}{l}\text { Short-term economic impact by loss } \\
\text { of forest through conversion to } \\
\text { more developed land use }\end{array}$ \\
\hline Conservation & Less than 200 acres/year & $\begin{array}{l}\text { Small parcels located adjacent to } \\
\text { other conservation areas }\end{array}$ & $\begin{array}{l}\text { Focused on water } \\
\text { supply protection } \\
\text { conserved to protect } \\
\text { recreation/scenery in } \\
\text { wealthy communities. }\end{array}$ & $\begin{array}{l}\text { Lack of government coordination } \\
\text { and incentives } \\
\text { Developed land uses considered } \\
\text { more economically beneficial } \\
\text { There is interest in conserving } \\
\text { water quality. }\end{array}$ \\
\hline
\end{tabular}


Rhode Island Scenario Workshop, 11.4.15

Whispering Pines Conference Center, University Of Rhode Island

\section{Scenario 4: A Wrinkle in Time}

Drivers: weak land stewardship ethic, strong, coordinated government

\section{Storyline:}

- Cookie cutter houses, kids all going in for dinner at the same time, etc.

- No one wants to use the land or recreate in open space

- Government tries to provide for material needs for the people at the lowest cost

- Village focused development and Smart Growth - promotes nucleated living patterns because cheaper for the government to provide clustered services, e.g. cheaper to run buses, etc.

- Promotion and incentives for small business - government listen to their analysts, which means that jobs are promoted at the small business level (rather than aim for getting the Toyota factory once every 30 years)

- There is government interest in ecosystem services as more cost effective than replacing them with engineered systems. Government's analysts on this - good analysts and they would be listened to

- The conservation lands would look like the Providence Water Supply Board. Wouldn't need to fence it or put signs because no one wants to go to the woods.

- No one cares about the woods except the government, and only as long as providing clean water and storm/flood protection, etc. (e.g. a bit of vulnerability because if the accounting changed, then

- Would not conserve rare species - because no rare species that are economically valuable (so disappearance of rare species).

- Energy costs, - the group couldn't decide on how exactly it would play out for energy production. Might be that energy decides that hydro-energy imported from Canada might be the way to go, or might be technology for local generation energy has improved, so then incentivize it, etc. It was clear that energy costs were high, the scenario would be reinforced, and it would be incentivized to cluster, and use little energy. And if low energy costs, the government doesn't much care if people are out in the sticks/rural areas, drive SUVs to work etc.

- As there was a powerful government, in contrast there would be a few and not very powerful NGOs.

\section{PROS:}

- Would have beneficial conservation effects through interest in conserving ecosystem services

- Coordinated government response leads to smart growth, energy efficiency, strong local economies

CONS::

- No trails, or signage, etc. on conservation lands

- Conservation lands would be at risk, because their value is determined only by the 'economic' equation, and no other value attached (so could be vulnerable in that sense)

- People wouldn't care to go outside. Instead looking at IPADs, or do other activities on actor-turf 
Rhode Island Scenario Workshop, 11.4.15

Whispering Pines Conference Center, University Of Rhode Island

Table A2.20. Scenario 4: A Wrinkle in Time

\begin{tabular}{|c|c|c|c|c|}
\hline Land use & How Much? & Where? & What kind? & Why? \\
\hline $\begin{array}{l}\text { Forest to } \\
\text { Development }\end{array}$ & $<19 \%$ of current rate & $\begin{array}{l}\text { Fringe of existing development } \\
\text { and fringe of agriculture. }\end{array}$ & Compact mixed use & Smart growth \\
\hline $\begin{array}{l}\text { Forest to } \\
\text { Agriculture }\end{array}$ & $\begin{array}{l}\text { Significant increase over current rate } \\
\text { accelerating for } 20 \text { years than trailing } \\
\text { off }\end{array}$ & Around existing agriculture & $\begin{array}{l}\text { Conversion of forest } \\
\text { land to pasture }\end{array}$ & $\begin{array}{l}\text { Small business benefits of local } \\
\text { agriculture continues }\end{array}$ \\
\hline $\begin{array}{l}\text { Timber } \\
\text { Harvesting }\end{array}$ & $\begin{array}{l}\text { Increase of less than } 10 \% \text { over present } \\
\text { rate }\end{array}$ & In present forests & All types & $\begin{array}{l}\text { Encourage small business but } \\
\text { may be limited market for } \\
\text { timber }\end{array}$ \\
\hline Conservation & Rate of conservation slows by $2 / 3$ rds & $\begin{array}{l}\text { Around assets that provide } \\
\text { ecosystem services }\end{array}$ & $\begin{array}{l}\text { Little land being } \\
\text { protected in } \\
\text { perpetuity for } \\
\text { habitat instead being } \\
\text { set aside for } \\
\text { ecosystem services }\end{array}$ & \\
\hline
\end{tabular}


New Hampshire Island Scenario Workshop Summary

November 16, 2015

Robert S. Pierce Laboratory, Hubbard Brook

Population moves out of state and concentrated

settlement

Scenario 1:

Rise of the Cities
Scenario 2:

Small is Beautiful

\section{Conventional energy; lack of} innovation; higher carbon

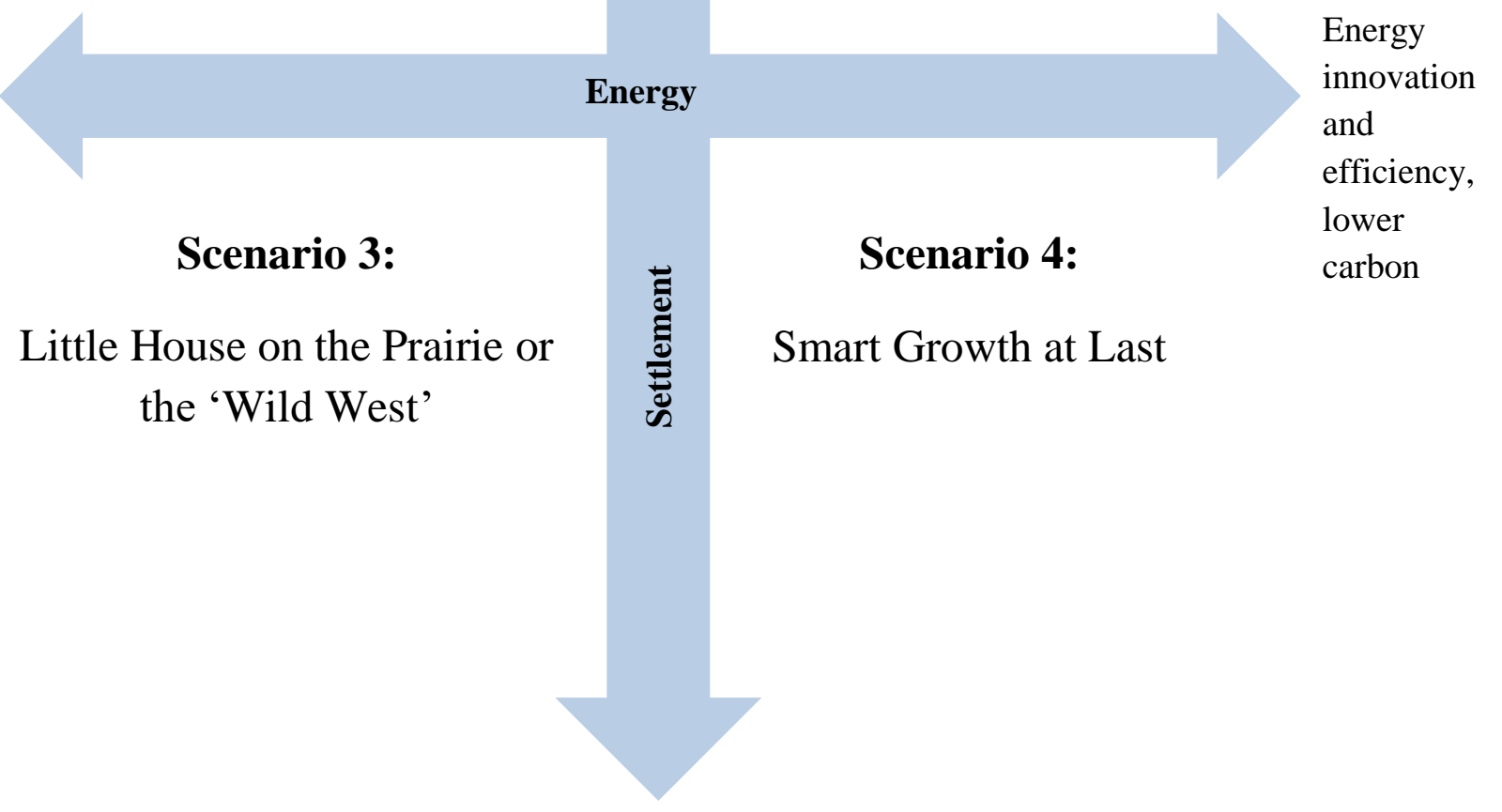

Population moves into state and dispersed settlement

Fig. A2.6. New Hampshire scenario matrix 


\section{Scenario 1: Rise of the Cities}

Drivers: conventional energy, higher carbon, loss of population and concentrated settlement patterns.

\section{Storyline:}

- Rise of the cities - high carbon, urbanizing, net loss of population

- Get there by continuing what we are already doing, we get older, move to urban areas with better services. Kids do too because there are no jobs in the rural areas.

- Don't change energy polices and don't actively manage the future

- No economic development

- Forests remain mostly forested. Loss of population in Northern part of state. Derelict towns due to population loss

- Because high carbon future, increase infrastructure, so cities now exist without the resources to address them (?)

- Potentially land becomes cheaper, which could make it a bit easier for land conservation, but kind of like what's happening in Burlington

- A wild card in terms of impact of climate, because if there are severe climate impacts, then people moving in, could be conflict.

- Economic gradient - poor rural areas and more affluent cities

- Possible expansion of second homes

- Continued current forest management practices and lower diversity of forest species due to $\mathrm{CC}$.

PROS:

- Southern New Hampshire could be a nice place to live with more vibrant city and town centers

- Potentially more local agriculture in southern portion of the state

- Forests remain forested

- Less pressure on resources

CONS:

- High disparity between economies of northern and southern $\mathrm{NH}$

- Increased income inequality

- No active management of the future

- More pressure on infrastructure in cities

- Ghost towns in North

- Displacement of populations by severe climate change events

- Movement into urban towns which tend to be near water could present problems with climate change

- Increased forest disturbance from forest pests and climate change 
Table A2.21. Scenario 1: Rise of the Cites

\begin{tabular}{|c|c|c|c|c|}
\hline Land use & How Much? & Where? & What kind? & Why? \\
\hline $\begin{array}{l}\text { Forest to } \\
\text { Development }\end{array}$ & $\begin{array}{l}\text { Lower than recent trends. Net loss }=0 \\
\text { acres/year } \\
2015 \text { 2k/yr } \\
2065\end{array}$ & $\begin{array}{l}\text { 1. Loss of forest around } \\
\text { cities south of White } \\
\text { Mountain National Forest. } \\
\text { 2. Gain of forest in rural } \\
\text { areas. }\end{array}$ & $\begin{array}{l}\text { Residential; high } \\
\text { density patch } \\
\text { expansions around } \\
\text { cities. }\end{array}$ & $\begin{array}{l}\text {-People leaving rural areas and } \\
\text { development concentrates in } \\
\text { cities. } \\
\text {-Forest loss around cities } \\
\text { balanced by forest gains in rural } \\
\text { areas. }\end{array}$ \\
\hline $\begin{array}{l}\text { Forest to } \\
\text { Agriculture }\end{array}$ & $\begin{array}{l}\text { Near term Increase in rate of conversion } \\
\text { followed by decline and stabilization at } \\
12 \% \text { if state in } 2060\end{array}$ & $\begin{array}{l}\text { Prime ag. Soils, gentle slope } \\
\text { in rural areas in vicinity of } \\
\text { urban areas south of White } \\
\text { Mountain National Forest }\end{array}$ & $\begin{array}{l}\text { Cropland on } \\
\text { undeveloped prime } \\
\text { soils; remaining } \\
\text { pasture }\end{array}$ & $\begin{array}{l}\text { High energy costs makes food } \\
\text { transport more expensive; } \\
\text { longer growing seasons, local } \\
\text { food movement, climate change } \\
\text { impacts to major agricultural } \\
\text { regimes. }\end{array}$ \\
\hline Timber Harvesting & Increase to $75 \mathrm{~K} /$ Year in 2060 & $\begin{array}{l}\text { Continuation on current } \\
\text { managed lands; increase } \\
\text { from family forests south of } \\
\text { White Mountain National } \\
\text { Forest }\end{array}$ & & $\begin{array}{l}\text {-Increased demand for wood } \\
\text {-increased cost of transport from } \\
\text { outside region due to energy } \\
\text { costs } \\
\text {-rural poverty/economic need } \\
\text {-demand for firewood because } \\
\text { of high energy costs } \\
\text {-sale of family forests to timber } \\
\text { interests }\end{array}$ \\
\hline Conservation & $\begin{array}{l}\text { Increased rate of conservation over next } \\
25 \text { years, then decline until } 42 \% \text { if state } \\
\text { is conserved in } 2060\end{array}$ & $\begin{array}{l}\text { Larger family forests; } \\
\text { commercial lands in Coos } \\
\text { County }\end{array}$ & $\begin{array}{l}\text { Mostly easement; } \\
\text { public and NGO fee } \\
\text { purchase of high value } \\
\text { lands (continuation of } \\
\text { current pattern) }\end{array}$ & $\begin{array}{l}\text {-Larger family forest owners } \\
\text { (both conservation ethic and } \\
\text { financial incentives) } \\
\text {-Cheaper land due to rural } \\
\text { poverty } \\
\text {-urban populations desiring } \\
\text { natural amenities }\end{array}$ \\
\hline
\end{tabular}




\section{Scenario 2: 'Small is Beautiful'}

Drivers: declining, concentrated population, innovative and efficient energy

Storyline:

- Declining population, low carbon energy footprint

- Young people have been moving out of the state to find good jobs, more vibrant culture, etc.

- Remaining population moves back to village centers and population concentrates.

- Economy declines, only rich, well-educated can afford to remain, young have moved

- Community solar farms around the landscape.

- New farms are built to be energy independent.

- Ring of ag land around developed core - back to village concept

- Seeing less cars and more reliance on transportation hubs.

- In villages, more sidewalks and trails to avoid car use.

- Affluent population, can rely more on local food, which leads to supporting local agricultural land.

- Another perspective - counter to the above, there is some possibility that young might actually find jobs, there may actually be opportunities with the new energy

- More seasonal population, possibly more second homes.

PROS:

- Energy efficiency and independence

- More reliance on transportation hubs

- More village development and more sidewalks and trails to avoid car use

- Support for local agriculture and much of ag. land is under permanent protection

- State remains an outdoor recreation destination

- Health benefits

CONS:

- Economy declines

- Taxes high to support services for small core population

- Diversity low

- Healthier population 
Table A2.22. Scenario 2: Small is Beautiful

\begin{tabular}{|c|c|c|c|c|}
\hline & How Much? & Where? & What kind? & Why? \\
\hline $\begin{array}{l}\text { Forest to } \\
\text { Development }\end{array}$ & $\begin{array}{r}\text { Limited and possibly no net loss of } \\
\text { forested landscape }\end{array}$ & & $\begin{array}{l}\text { Impact on urban shade trees } \\
\text { Landscape impact unknown }\end{array}$ & $\begin{array}{l}\text { Decreased and dispersed } \\
\text { population and clustering in } \\
\text { cities }\end{array}$ \\
\hline $\begin{array}{l}\text { Forest to } \\
\text { Agriculture }\end{array}$ & $\begin{array}{l}10 \% \text { conversion of forests to } \\
\text { agriculture }\end{array}$ & $\begin{array}{l}\text { Close to population } \\
\text { centers }\end{array}$ & $\begin{array}{l}\text { Conversion to small parcel } \\
\text { agricultural }\end{array}$ & $\begin{array}{l}\text { More local food interest and } \\
\text { dependence }\end{array}$ \\
\hline $\begin{array}{l}\text { Timber } \\
\text { Harvesting }\end{array}$ & $55 \%$ of the harvestable acres & $\begin{array}{l}\text { Developed } \\
\text { areas } \\
\text { Agricultural } \\
\text { conversion } \\
\text { Northern Forest }\end{array}$ & $\begin{array}{l}\text { Low intensity, sustainable } \\
\text { forestry }\end{array}$ & $\begin{array}{l}\text { Primarily for local markets; } \\
\text { lumber firewood, pellets, } \\
\text { biomass }\end{array}$ \\
\hline Conservation & $\begin{array}{l}25 \% \text { of New Hampshire would be } \\
\text { conserved }\end{array}$ & $\begin{array}{l}\text { Ag soils around water } \\
\text { resources }\end{array}$ & Conservation easements & $\begin{array}{l}\text {-More land available and } \\
\text { cheaper as it is vacated. } \\
\text { - Increasing demand for } \\
\text { outdoor recreation. } \\
\text {-Land conserved for legacy. }\end{array}$ \\
\hline
\end{tabular}




\section{Scenario 3: "Smart Growth at Last"}

Drivers: population moving in, dispersed settlement patterns, energy innovation

\section{Storyline:}

- Every acre is being used in some fashion (this drivers the need and interest in smart growth)

- Follows the idea of 'dispersed clustering' - population/settlement patterns dense in places where there is a town, but these town centers are far apart and there is a large development imprint on the landscape

- Perhaps because of population growth and development people recognize the value of the landscape and try to cluster growth where possible

- Landscape looks like New Hampshire in the 1800's. Land use is fairly scattered, more farmlands to grow more fuels, on good soils.

- There are migration pressures from Southwest United States, and areas drying up, and pressure from coastal regions with sea level rise.

- Development builds outwards from the town centers

- Transportation maybe shifting towards tele-commuting with more innovative transportation patterns generally

- Energy could be produced on rooftops, wind etc.

- Some uncertainty about social equity - who can afford living in these places. Some in the group not sure about distribution of economic classes

- The entire landscape is put to use

PROS:

- Recognition of the need for smarter, planned town centers and clustered growth

- Forest land is valued in this innovated future, and to deal with it, there would be the clustered smart growth to avoid misuse/opportunity costs.

- Maybe climate pressures are being alleviated by shift to local food sources, less transportation, etc.

- Wildlands valued and used for carbon storage, wildlife, etc.

\section{CONS:}

- Much of the landscape is used for housing, forestry or farmland

- Significant pressures on natural resources

- Increased patchiness in landscape for food production and development

- Possible social equity issues and greater disparity between rich and poor across the landscape

- Possible conflicts around increasing demands for resources and sustainable use. 
Table A2.23. Scenario 3: Smart Growth at Last

\begin{tabular}{|c|c|c|c|c|}
\hline Land use & How Much? & Where? & What kind? & Why? \\
\hline $\begin{array}{l}\text { Forest to } \\
\text { Development }\end{array}$ & $\begin{array}{l}4,5000-5,000 / \text { year } \\
\text { (assumes } 1,807 \text { is } \\
\text { accurate for last } 15 \text { ) }\end{array}$ & $\begin{array}{l}\text { State-wide } \\
\text { Adjacent to existing centers }\end{array}$ & $\begin{array}{l}\text { But denser on each } \\
\text { converted acre }\end{array}$ & Population growth (in-migration) \\
\hline $\begin{array}{l}\text { Forest to } \\
\text { Agriculture }\end{array}$ & 2,000 acres/year & Distributed statewide & $\begin{array}{l}\text {-prime soils where } \\
\text { applicable } \\
\text {-more marginal soils where } \\
\text { justified by markets, etc. } \\
\text { upslope }\end{array}$ & $\begin{array}{l}\text { Growing more food locally (both by } \\
\text { choice and necessity) }\end{array}$ \\
\hline $\begin{array}{l}\text { Timber } \\
\text { Harvesting }\end{array}$ & 75,000 acres/year & Statewide & $\begin{array}{l}\text {-Lots of initial low-grade for } \\
\text { biomass } \\
\text {-thinning for saw timber (for } \\
\text { long-lived products and } \\
\text { carbon sequestration) }\end{array}$ & $\begin{array}{l}\text {-More local wood production } \\
\text {-Sequester carbon } \\
\text {-Housing more people }\end{array}$ \\
\hline Conservation & 15,000 acres/year & Statewide & $\begin{array}{l}\text { Targeted to purposes under } \\
\text { why }\end{array}$ & $\begin{array}{ll}\text { - } & \text { permanent green infrastructure } \\
\text { - } & \text { for } \\
\text { - } & \text { carbod and fiber } \\
\text { - } & \text { water quality and quantity } \\
\text { - } & \text { biodiversity } \\
\text { - } & \text { storm water mitigation } \\
\text { - } & \text { recreation }\end{array}$ \\
\hline
\end{tabular}




\section{Scenario 4: "Little House on the Prairie" or "The Wild West"}

Drivers: population moving in and dispersed, conventional energy and higher carbon

\section{Storyline:}

- Looks a lot like today, but a more extreme trend in that direction

- The wealthy folks who are able to live here have stayed

- Everything is fragmented, making it depend on where you are in the state what is going on. There are some nice village centers in the south of the state. The North is very poor.

- As real estate prices collapse, then people live in poverty, and extract whatever they can (eking out a living, maybe gardens, etc.?) from the landscape

- Still have to be increasing the carbon production, so the group had a question

- Question the group had: not sure if these can co-exist. (E.g. carbon prices go up, so can't afford to live there. Or the weather changes, and washes out the roads

- Little to no investment in transportation.

- What would civic engagement look like? Would wealthy populations just keep to themselves, or there is the possibility that they are more civically minded.

- Different looking forest both because of forest management practices or because of the climate

- Infrastructure is dispersed, which brings up the issue of sustainability and whether you can keep it going.

- Kept thinking that would self-regulate. E.g. if a high carbon price future, how could people afford to live? People who can't live there, end up clearly their whole wood lot just to survive. While people who can afford, can drive anywhere.

- What happens to forest management and timber harvest under this scenario?

PROS:

- Some possibility of self-regulation at some point in the scenario to try to fix energy situation.

CONS:

- Public land access goes out the window.

- Poor land use practices 
Table A2.24. Scenario 4: Little House on the Prairie

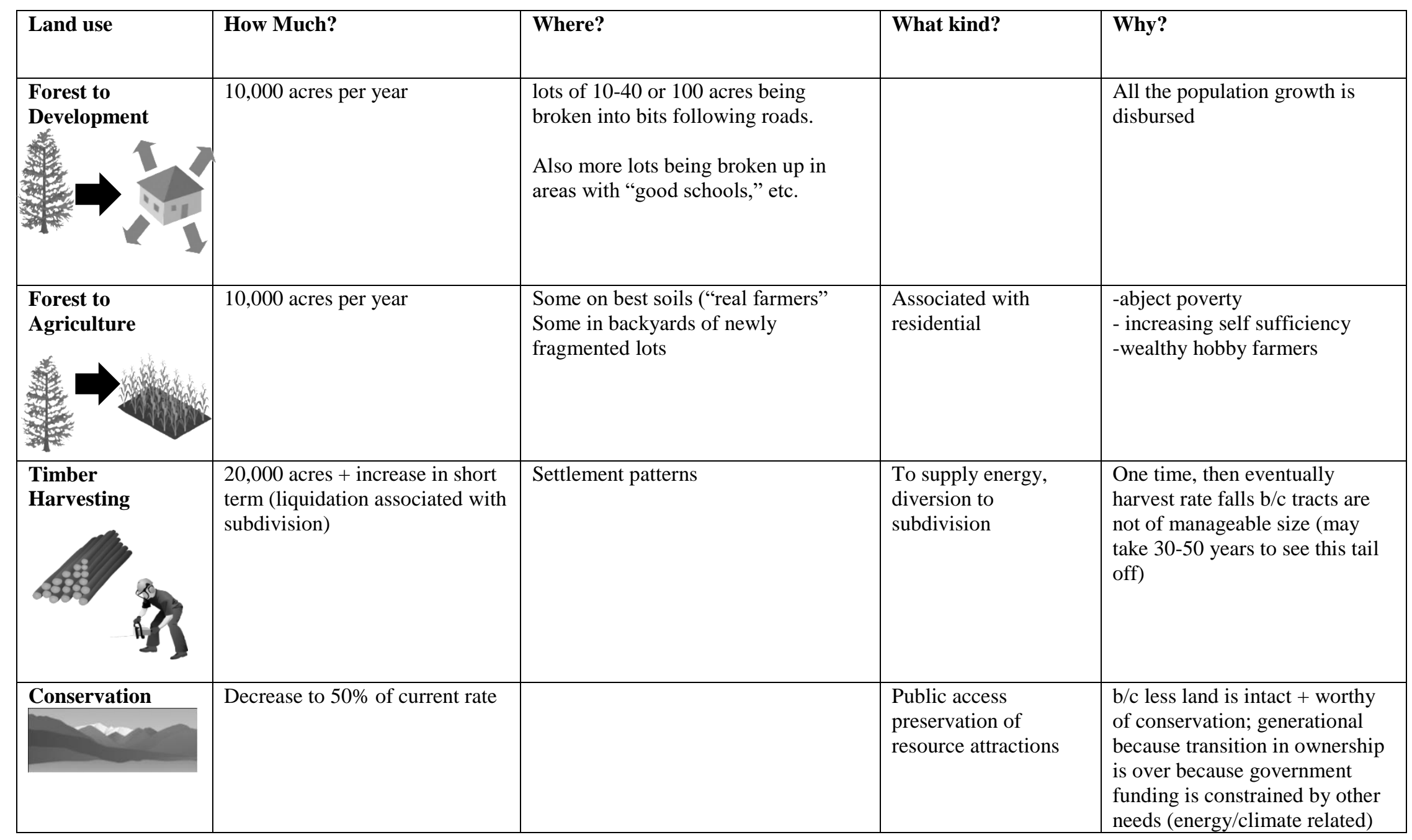




\section{Appendix 3. New England 2060 scenario narratives}

This document presents four scenarios that describe potential changes in the New England landscape to the year 2060. The scenarios were developed with 120 stakeholders from the six New England states through a series of scenario-building workshops led by the Harvard Forest as part of the New England Landscape Futures Project and the Scenarios, Services, and Society Research Coordination Network. The scenarios represent four plausible alternatives to current trends built around two drivers of landscape change that are considered highly uncertain and high-impact: Natural resource planning \& innovation (high or low) and Socio-economic connectedness (global or local). These two drivers form the axes and endpoints for the scenario matrix shown below. Each quadrant represents a future scenario with names that reflect their position in the matrix.

Fig. A3.1. New England regional scenario matrix

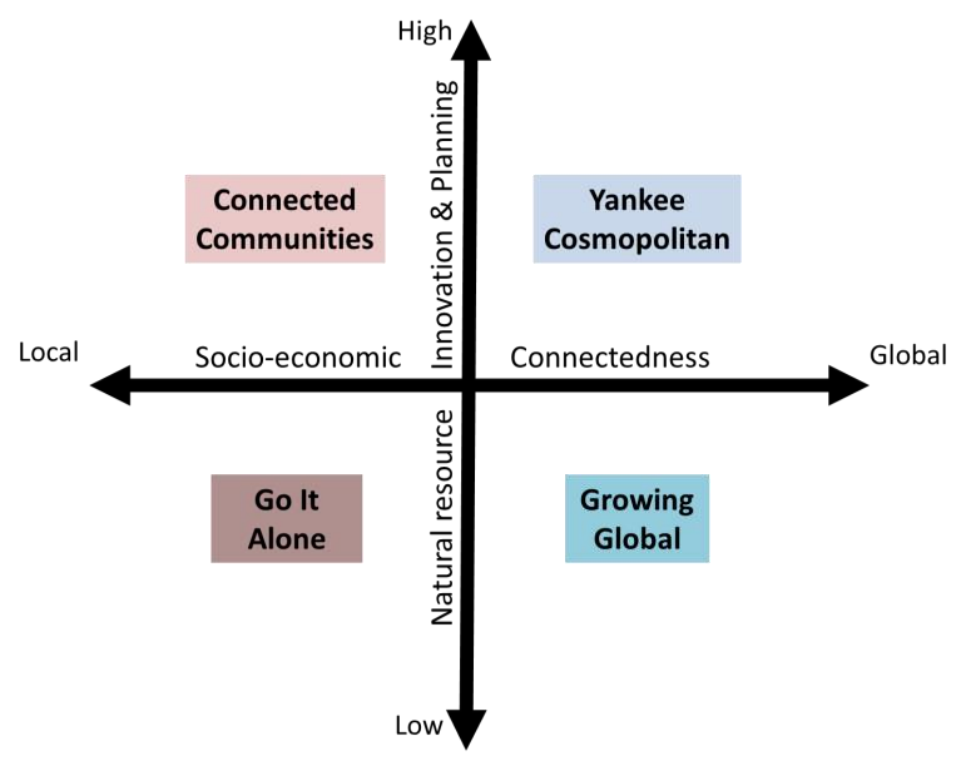

\section{Driver Definitions}

Socio-economic connectedness refers to the extent to which population migration, culture, economic markets, goods and services, and trade and climate policy are globally oriented or locally oriented.

Natural resource planning \& innovation refers to the extent to which governments engage in proactive land-use planning and invest in technological advances for land, energy, and water use. It also reflects the degree of private sector innovation in resource use and investment in ecosystem services. This driver also incorporates social attitudes of individuals toward land stewardship and sustainability.

\section{Narratives and Tables}

The pages that follow provide a narrative description of each scenario and a table comparing recent land use trends and land use trends for each scenario. Tables $1-4$ contain the number of hectares that transition under each land use category when annual results are extrapolated over 50 years. 


\section{Connected Communities}

High natural resource planning \& innovation / Local socio-economic connectedness

The World in 2060

SCENARIO IN BRIEF: The New England population has increased slowly over the past fifty years and most communities are coping with climate change by anchoring in place rather than relocating, making local culture and the use and protection of local resources increasingly important to governments and communities. New England has been less affected by climate change than many other regions of the U.S. in this scenario. Concerns about global unrest and the environmental impacts of global trade have led New Englanders to strengthen their local ties and become more self-reliant. These factors combine with heightened community interest and public policies to strengthen local economies and fuel burgeoning markets for local food, local wood, and local recreation.

SETTLEMENT PATTERNS: From the early 2020s onward, local and regional governments have used tax incentives, public policies, and market subsidies to drive a shift toward sustainability and climate resilience. ${ }^{1}$ This renewed focus on community planning and protection of natural resources has advanced 'smart growth' measures that balance development needs with the need to protect natural infrastructure ${ }^{2}$. New settlements tend to occur in planned urban centers ${ }^{3}$, resulting in higher density development (in-fill), and as pockets of clustered growth at the urban fringe. ${ }^{4}$

Reduced reliance on global trade and greater reliance on local natural resources has bolstered the availability of local jobs. Strong urban planning yields developments where more people can walk to work. ${ }^{5}$ The growth of urban farms and urban green infrastructure has also improved the quality of life for city dwellers. With the shift toward a more community-focused lifestyle, long-distance travel has declined and "stay-cations" at local recreation areas have become more popular. New parks and wilderness areas in northern New England also attract wealthy tourists from elsewhere and promote the development of more and larger high-end lakeside and mountainside resorts.

ENERGY AND CLIMATE: On-going concerns about climate change have fueled a grass-roots green energy movement, resulting in increased local wind, biomass, and solar power development. Proactive planning ensures that only a small amount of open land has been converted to developed uses to support these renewable energy projects. Over time, technological advances have increased energy efficiency and decreased the footprint of energy development. A regional carbon tax has made transportation more expensive, making local food supplies and shorter commutes more attractive. This helps to promote greater reliance on local food, local wood products and local transportation options during the early 2020s and 2030s, with local wood biomass serving as a renewable transition fuel.

\footnotetext{
${ }^{1}$ Probability of development is reduced by $-40 \%: 1 k,-30 \%: 2 k,-20 \%: 3 k$, and $-10 \%: 4 k$ away from the coast.

${ }^{2}$ All FEMA +1 foot sea level rise, FWS wetlands, and NHD flood risk zones are ineligible for development.

${ }^{3}$ Probability of development is increased by $30 \%$ within $1 \mathrm{k}$ of a city center with population over $10,000,29 \%$ within $2 \mathrm{k}, 28 \%$ within $3 \mathrm{k}$, ramping down to $1 \%$ within $30 \mathrm{k}$.

${ }^{4}$ Mean patch size for new development has been doubled. Isometry modifier increased from 1.1 to 1.2 . The ratio of new vs. expansion patches has been increased by +0.1 for all regions (a few regions max out at $100 \%$ by expansion).

${ }^{5}$ Probability of development is increased close to town centers. $+30 \%: 1 \mathrm{k},+25 \%: 2 \mathrm{k},+20 \%: 3 \mathrm{k},+15 \% 4 \mathrm{k},+10 \%: 5 \mathrm{k}$.
} 
LAND PROTECTION: With the interest in localism there is a strong focus on the protection of wildlands for wildlife and ecosystem services. ${ }^{6}$ With increased reliance on local resources and greater public investment in natural infrastructure, rates of private land protection through easements rise, and payments for ecosystem services, such as clean water, have surpassed the value landowners derive from resource extraction. Easements on lands that are harvested are a common means of shoring up local wood markets. State and local governments have invested greater public funding in land protection for forest health, flood control, and water quality. ${ }^{7}$ Municipal governments are also protecting land for public parks near population centers. ${ }^{8}$ Larger TIMOs ${ }^{9}$ and REITs ${ }^{10}$ have divested land to local governments and private landowners who manage for wood and water.

FARMING: Local agriculture has expanded to meet the growing demand for local food. A renaissance of smallscale community-based farming has occurred with new farms often situated on the outskirts of town ${ }^{11}$, growing mixed, diverse crops. Farming is highly efficient with plants engineered for the novel climate that require minimal water, fertilizer, and pesticide application. This renaissance has brought reinvestment in slaughterhouses and smokehouses to supply the region with meat from local sources.

FORESTRY: The harvesting and use of local wood is supported by the strong "buy local" movement as well as by new incentives for building with wood and a high carbon tax on imported wood products. As a result, timber harvesting rates across the region increase by $50 \%$ by 2060 , particularly in the northern New England states. Investment timber owners are paid by governments and fund managers to manage sustainably for timber, watershed protection, and other ecosystem services. The existence of biomass energy markets makes the removal of traditionally low-value timber species and size-classes cost-effective, and there is a resurgence in community forests and woodlots near towns that are dedicated to producing high-value local wood products.

Table A3.1. New Transitions 2010-2060 (Connected Communities)

\begin{tabular}{ccccc}
\hline \hline & Agriculture (ha) & Development (ha) & Conservation (ha) & Harvest (ha) \\
\hline State & scenario / recent trends & scenario / recent trends & scenario / recent trends & scenario / recent trends \\
\hline CT & $15,263 / 6,341$ & $18,507 / 76,120$ & $185,536 / 109,859$ & $61,517 / 40,966$ \\
ME & $11,906 / 45,569$ & $32,375 / 125,462$ & $2,858,841 / 2,774,258$ & $735,283 / 726,184$ \\
MA & $18,227 / 7,002$ & $41,576 / 136,875$ & $482,542 / 273,983$ & $58,250 / 59,717$ \\
NH & $28,881 / 10,353$ & $22,715 / 98,908$ & $628,918 / 546,110$ & $111,190 / 106,122$ \\
RI & $2,176 / 845$ & $3,807 / 16,780$ & $64,102 / 40,181$ & $7,008 / 6,680$ \\
VT & $27,910 / 12,806$ & $7,470 / 30,503$ & $1,003,275 / 430,652$ & $102,314 / 112,768$ \\
TOTAL & $205,364 / 82,917$ & $126,451 / 484,648$ & $5,223,213 / 4,175,044$ & $1,075,562 / 1,052,437$ \\
\hline
\end{tabular}

\footnotetext{
${ }^{6}$ Probability of conservation types Private Reserves, Private Working Forests, and Small Private Multi-Use forests have probability increased by $10 \%$ in all high priority conservation areas (State Wildlife Action Plans).

${ }^{7}$ Probability of conservation type Public Multi Use increase by $20 \%$ in all high priority conservation areas (State Wildlife Action Plans) and in the top $25 \%$ Forest to Faucets defined high importance watersheds, plus a further increase of $10 \%$ in FEMA and NHD flood zones.

${ }^{8}$ Probability conservation type Public Park is increased by $30 \%$ within $1 \mathrm{k}$ of city centers with populations over $10,000,29 \%$ within $2 \mathrm{k}, 28 \%$ within $3 \mathrm{k}$, ramping down to $1 \%$ within $30 \mathrm{k}$.

${ }_{9}$ Timber Investment Management Organization

${ }^{10}$ Real Estate Investment Trust

${ }^{11}$ Probability of new agriculture is increased by $30 \%$ within $1 \mathrm{k}$ of urban areas, $29 \%$ within $2 \mathrm{k}, 28 \%$ within $3 \mathrm{k}$, ramping down to $1 \%$ within $30 \mathrm{k}$.
} 


\title{
Yankee Cosmopolitan
}

\section{High natural resource planning \& innovation / Global socio-economic connectedness}

\author{
The World in 2060
}

SCENARIO IN BRIEF: New England has experienced substantial population growth spurred by climate and economic migrants who are seeking areas less vulnerable to heat waves, drought, and sea-level rise ${ }^{12}$. Most migrants are international but some have relocated from more climate-affected regions in the U.S. At the same time, a strong track record in research and technology has made New England a world leader in biotech and engineering, creating a large demand for skilled labor. The region's relative resilience to climate change and growing employment opportunities has made New England a major economic and population growth center of the U.S. Abundant forests remain a central part of New England's identity, and support increases in tourism, particularly in Vermont, Maine, and New Hampshire.

SETTLEMENT PATTERNS: Proactive city planning as well as public and private investment in infrastructure have helped to meet the needs of New England's growing population through well-planned housing, transportation hubs, and municipal services near city centers. ${ }^{13} 1415$ These well-planned urban hubs are attractive places to work and live. This, together with the increasingly global community, creates diverse neighborhoods with unique cultural, business, and natural amenities. As the population influx continues through the 2030s and 2040s, the pace of development begins to exceed the planning and physical capacity of many cities and development patterns devolve into sprawl. ${ }^{16}$ Except for areas with high tourism, the population of rural areas is steady or declining throughout northern New England, resulting in little new permanent development in that part of the region.

ENERGY AND CLIMATE: A global shift toward sustainability with strong global climate agreements has created robust global carbon markets and carbon storage by forests is now highly valued. The strong carbon offset market encourages regional brokers to work with small-scale forest and farm landowners to bundle and market their carbon storage. Policies and private sector investments in new technology help to curtail greenhouse gas emissions and support the development of low-carbon renewable energy technologies. As part of this 'green' economy shift, New England has seen the propagation of significant numbers of renewable energy sites throughout each state to meet the energy needs of a growing population. Wind turbines span shorelines and ridgelines near growth centers. Large solar arrays built during the 2020 s consume large tracts of land but eventually give way to less expansive, more efficient systems in response technological innovation and heightened demand for land for housing.

\footnotetext{
12 Probability of development is reduced by $20 \%$ within $500 \mathrm{~m}$ of the coast, $-19 \% 1000 \mathrm{~m}$ from the coast, $-18 \% 1500 \mathrm{~m}$ from the coast, down to $-1 \% 20 \mathrm{k}$ from the coast. All NOAH +1 foot costal flood zones have no chance of development.

${ }^{13}$ Probability of development is increased by $30 \%$ within $1 \mathrm{k}$ of city centers with populations over $10,000,29 \%$ within $2 \mathrm{k}, 28 \%$ within $3 k$, ramping down to $1 \%$ within $30 k$.

${ }^{14}$ Reduced probability of development on prime agricultural soils by $10 \%$.

${ }^{15}$ All FEMA and NHD flood risk zones have probability of development reduced by $20 \%$.

${ }^{16}$ Clustered development for the first 20 years only. Mean patch size for new development has been doubled. Isometry modifier increased from 1.1 to 1.2. The ratio of new vs. expansion patches has been increased by +0.1 for all regions (a few regions max out at $100 \%$ by expansion). From 2030 onward, patterns follow recent trends.
} 
LAND PROTECTION: Smart growth, high-density urban development, and carbon offset markets have facilitated a doubling in rates of land protection within high priority conservation areas ${ }^{17}$ throughout the 2020s and 2030s. New urban parks track with new development. ${ }^{18}$ Bundled carbon markets result in many new conservation easements. Land protection priorities focus on the maintenance of ecosystem services, particularly in southern New England where cities depend on watershed lands for low-cost, clean drinking water. ${ }^{19}$ Even so, land protection is under pressure from rapid population growth and, aside from small public parks, most land protection for ecosystem services occurs in low-population areas, with conflicts between ecosystem service protection and development hindering land protection in other regions.

FARMING: In this globally connected world, there is little drive for self-sufficiency in food supplies, and the U.S. relies on imports for most products, except for specialized local food such as organic milk, apples, maple syrup, and potatoes. Innovative farming practices support increased production without much additional agricultural acreage. In northern New England a modest increase in agriculture occurs near existing farms and some small patch farming emerges near towns to feed local niche markets. ${ }^{2021}$

FORESTRY: Rates of timber harvesting for wood products have decreased in the region, particularly in southern New England where parcelization and non-timber forest values drive land management priorities. Technological innovations in energy generation and storage limit the demand for wood biomass energy. Much of the land owned by TIMOs and REITs has been enrolled in carbon markets to capitalize on the boom in carbon offset prices. Development of sugar bushes has expanded as maple syrup has become a valuable global commodity and New England remains suitable for sugar maple trees despite changing climate. Consistent with a world with competing demands for forest uses, forestry practice laws designed to protect a range of ecosystem services have become more stringent in all states and the limited harvesting that occurs follows an 'ecological forestry' paradigm, including longer rotations with more leave trees and slash left on-site to balance carbon storage with commodity production.

Table A3.2. New Transitions 2010-2060 (Yankee Cosmopolitan)

\begin{tabular}{ccccc}
\hline \hline & Agriculture (ha) & Development (ha) & Conservation (ha) & Harvest (ha) \\
\hline State & scenario / recent trends & scenario / recent trends & scenario / recent trends & scenario / recent trends \\
\hline CT & $6,313 / 6,341$ & $155,798 / 76,120$ & $163,813 / 109,859$ & $18,137 / 40,966$ \\
ME & $45,349 / 45,569$ & $93,037 / 125,462$ & $2,135,258 / 2,774,258$ & $462,105 / 726,184$ \\
MA & $6,689 / 7,002$ & $251,633 / 136,875$ & $418,4422 / 273,983$ & $26,380 / 59,717$ \\
NH & $11,374 / 10,353$ & $119,745 / 98,908$ & $505,223 / 546,110$ & $66,787 / 106,122$ \\
RI & $922 / 845$ & $36,759 / 16,780$ & $59,382 / 40,181$ & $3,012 / 6,680$ \\
VT & $12,154 / 12,806$ & $22,335 / 30,503$ & $397,548 / 430,652$ & $71,087 / 112,768$ \\
TOTAL & $82,801 / 82,917$ & $679,307 / 484,648$ & $3,679,666 / 4,175,044$ & $647,510 / 1,052,437$ \\
\hline
\end{tabular}

\footnotetext{
17 Probability of conservation has been increased by $20 \%$ on all high priority conservation areas (State Wildlife Action Plans). 18 Probability of new public park creation is increased by $30 \%$ within $1 \mathrm{k}$ of city centers with populations over $10,000,29 \%$ within $2 \mathrm{k}, 28 \%$ within $3 \mathrm{k}$, ramping down to $1 \%$ within $30 \mathrm{k}$.

${ }^{19}$ Probability of conservation has been increased by $20 \%$ in MA, CT, and RI in the top $25 \%$ Forest to Faucets defined high importance watersheds.

${ }^{20}$ All non-prime agricultural soils are ineligible for new agriculture.

${ }^{21}$ Zero probability of new agriculture within Census Urban Areas, but increase by $30 \%$ within $1 \mathrm{k}, 29 \%$ within $2 \mathrm{k}, 28 \%$ within $3 \mathrm{k}$, down to $1 \%$ within $30 \mathrm{k}$ of the urban area boundary.
} 


\section{Growing Global}

Low natural resource planning \& innovation / Global socio-economic connectedness

The World in 2060

SCENARIO IN BRIEF: By 2060, a steady stream of migrants has driven up New England's population, with newcomers seeking to live in areas with few natural hazards, ample clean air and water, and low vulnerability to climate change. This influx of people has taken the region by surprise and local planning efforts have failed to keep pace with development. The region has experienced increasing privatization of municipal services as state and local governments struggle to keep up with the needs of the burgeoning population. Trade barriers were lifted in the 2020s to counter economic stagnation and the volume of global trade has multiplied over the past 40 years as a result of increasing globalization. However, all attempts at global climate change negotiations and renewable energy commitments have failed in this globally divided world.

SETTLEMENT PATTERNS: New England is characterized by sprawling cities with poor transportation infrastructure, inefficient energy use, and haphazard expansion of residential development. Walkability in most cities is low and cars remain necessary to access services in most parts of the region. ${ }^{22}$ Little has been done to address stresses on civil infrastructure. Development pressures and loss of open space are particularly acute in southern New England around Boston, Nashua, Springfield and Hartford. However, northern New England cities are not immune, and Portland and Burlington have experienced heightened expansion. ${ }^{23}$

ENERGY AND CLIMATE: In this world with little innovation and no global commitment to climate action, conventional fossil fuel energy sources dominate and remain abundant and cheap. Despite the environmental costs associated with conventional energy, levels of transportation and mobility remain high both locally and globally. New England has experienced some investment in new renewable energy, but much more development of natural gas and overland transmission lines. Haphazard harvesting of forests for woody biomass has increased.

LAND PROTECTION: With the region's growing population and low natural resource planning, investment in natural infrastructure continues to be low and land protection rates have been in sharp decline. Where new land conservation occurs, it is mostly for tax purposes and in remote areas under little threat of development. Existing parks and protected lands are heavily used and ecologically degraded. New residential and commercial development around parks serve the wealthy and perforate forests around protected lands. ${ }^{24}$ Efforts to 'green-up' cities focus on protecting recreation areas rather than natural infrastructure. Conservation easements on private lands have been legally challenged so that landowners can exploit natural gas and other energy resources.

FARMING: U.S. food exports surge in response to changing global agricultural commodity markets, and drive the conversion of forestland to farmland. These new agricultural lands mostly extend out from existing farmland ${ }^{25}$, and typically take the form of large-scale, intensive production farms for commodity crops by leading multi-

\footnotetext{
22 Increase probability around highways by $20 \%-100 \mathrm{~m} 15 \%-200 \mathrm{~m} 10 \%-300 \mathrm{~m}$ 5\%-400 so that cities sprawl along transportation corridors.

24 Probability of new development has been increased by $10 \%$ within $90 \mathrm{~m}$ of all conservation area boundaries.

${ }^{25}$ All prime agricultural soil and non-prime soils within $300 \mathrm{~m}$ of prime soil are eligible for conversion to agriculture.
} 
national agri-businesses ${ }^{26}$ Consumers continue to demand a wide variety of high quality products available yearround and at low-cost. With cheap fossil fuel, imported agricultural products remain the dominant source of food for the region.

FORESTRY: The growth of the national housing market has led to an increase in the area of forestland that is harvested each year. This growth largely occurs in rural areas. In the northern New England states large-scale industrial forest management and clear-cutting rates have increased. Warmer growing conditions have led to experimentation with fast-growing softwoods such as loblolly and southern pine plantation forestry. However, the success of these plantations has been variable due to the long time horizon before a return on investment is realized. Accordingly, many large plantations have been converted to agriculture before reaching maturity. Conventional forestry has increased commensurate with expanded biofuel markets, often harvesting low value species. Nonetheless, rising property values and associated new development has driven forestry out of southern New England.

Table A3.3. New Transitions 2010-2060 (Growing Global)

\begin{tabular}{ccccc}
\hline \hline & Agriculture (ha) & Development (ha) & Conservation (ha) & Harvest (ha) \\
\hline State & scenario / recent trends & scenario / recent trends & scenario / recent trends & scenario / recent trends \\
\hline CT & $0 / 6,341$ & $56,320 / 76,120$ & $20,989 / 109,859$ & $115,017 / 40,966$ \\
ME & $0 / 45,569$ & $92,326 / 125,462$ & $555,960 / 2,774,258$ & $1,557,321 / 726,184$ \\
MA & $0 / 7,002$ & $108,871 / 136,875$ & $54,944 / 273,983$ & $168,868 / 59,717$ \\
NH & $0 / 10,353$ & $71,899 / 98,908$ & $102,836 / 546,110$ & $294,180 / 106,122$ \\
RI & $0 / 845$ & $12,058 / 16,780$ & $8,775 / 40,181$ & $18,703 / 6,680$ \\
VT & $0 / 12,806$ & $22,110 / 30,503$ & $91,427 / 430,652$ & $316,069 / 112,768$ \\
TOTAL & $0 / 82,917$ & $363,585 / 484,648$ & $834,931 / 4,175,044$ & $2,470,157 / 1,052,437$ \\
\hline
\end{tabular}

\footnotetext{
${ }^{26}$ Mean new agricultural patch size has been increased by $1000 \%$. The ratio of new vs. expansion has been increased by + 0.25 for all regions (some regions max out at $100 \%$ by expansion).
} 


\section{Go It Alone}

Low natural resource planning \& innovation / Local socio-economic connectedness

The World in 2060

SCENARIO IN BRIEF: Population growth in the region has remained fairly low and stable over the past 50 years as the lack of economic opportunity, high energy costs, and tightened national borders have deterred immigration and the relocation of people from within the U.S. to New England. The concurrent shrinking of national budgets and lack of global economic connections have left little leeway to deal with challenges such as high unemployment, demographic change, and climate resilience. Within New England this has resulted in the rolling back of natural resource protection policies and the drying up of investments in new technologies and ecosystem protections in response to a lack of regulatory drivers. Over the last 50 years, the region has seen the significant degradation of ecosystem services as a result of poor planning, increased pollution, and heavy extractive uses of local resources using conventional technologies.

SETTLEMENT PATTERNS: Rates of land development have slowed by about 25 percent compared to the 19902000s. Where development has continued, it is characterized by unplanned residential housing that perforates the landscape. Regional planning entities have closed shop and towns and unorganized townships must deal with development issues and municipal services on their own and with dwindling budgets. In most counties, public authorities lack the funds for the maintenance and extension of critical infrastructure such as roads, culverts and sewers. Over time, this infrastructure has begun to deteriorate, particularly in the poorer and more rural areas of New England.

ENERGY AND CLIMATE: Energy costs have continued to rise over the last half-century driven by crumbling conventional energy infrastructure, controversy over new energy development projects, and reduced access to global energy markets that persist in this more state-based world. International efforts to reduce greenhouse gas emissions have failed and conventional energy sources still dominate. High energy costs and poor infrastructure have made it expensive to travel and ship goods. It has become difficult for people to get around and there is resurgent localism in response. Lack of funding for climate change adaptation (e.g. upsizing road culverts) has also left rural communities stranded by rising floodwaters. Given the costs associated with mobility, relocating to more favorable areas is only an option for the affluent. Areas adversely affected by extreme weather endure long and steep economic declines. There is often a strengthening sense of community as people band together in times of scarcity, but many have still seen a considerable decrease in their quality of life.

LAND PROTECTION: Government entities have divested from land protection efforts and there has been little to no new land protection across the region. The protections offered by private land conservation easements often go unmonitored by now-defunct easement holders and are then challenged in court, such that there has been a net reduction in protected private land in areas experiencing development pressure.

FARMING: Growing instability in the global food supply has necessitated a shift toward local and subsistence food production. Counter-intuitively though, the amount of farmland in the region has declined due to the reduced presence of commercial agriculture in the region.

FORESTRY: In regions where the economy and real estate prices have collapsed, the people who remain need to extract what they can from the land. Therefore, timber harvesting rates have increased dramatically, precipitated 
by the need to use local resources for energy. There are few incentives to practice long-term silviculture and forests are heavily utilized for biomass energy, mostly for conventional firewood. The management and maintenance of TIMO and corporate forestry lands has declined because it is too expensive to harvest and transport wood products to distant population and energy centers.

Table A3.4. New Transitions 2010-2060 (Go It Alone)

\begin{tabular}{ccccc}
\hline \hline & Agriculture (ha) & Development (ha) & Conservation (ha) & Harvest (ha) \\
\hline State & scenario / recent trends & scenario / recent trends & scenario / recent trends & scenario / recent trends \\
\hline CT & $61,979 / 6,341$ & $152,035 / 76,120$ & $66,376 / 109,859$ & $74,486 / 40,966$ \\
ME & $442,492 / 45,569$ & $244,287 / 125,462$ & $1,660,664 / 2,774,258$ & $1,497,019 / 726,184$ \\
MA & $64,832 / 7,002$ & $385,648 / 136,875$ & $158,571 / 273,983$ & $156,599 / 59,717$ \\
NH & $121,190 / 10,353$ & $410,381 / 98,908$ & $348,491 / 546,110$ & $236,376 / 106,122$ \\
RI & $10,044 / 845$ & $48,983 / 16,780$ & $26,640 / 40,181$ & $17,405 / 6,680$ \\
VT & $131,528 / 12,806$ & $127,504 / 30,503$ & $244,219 / 430,652$ & $251,467 / 112,768$ \\
TOTAL & $832,066 / 82,917$ & $1,368,839 / 484,648$ & $2,504,960 / 4,175,044$ & $2,233,352 / 1,052,437$ \\
\hline
\end{tabular}
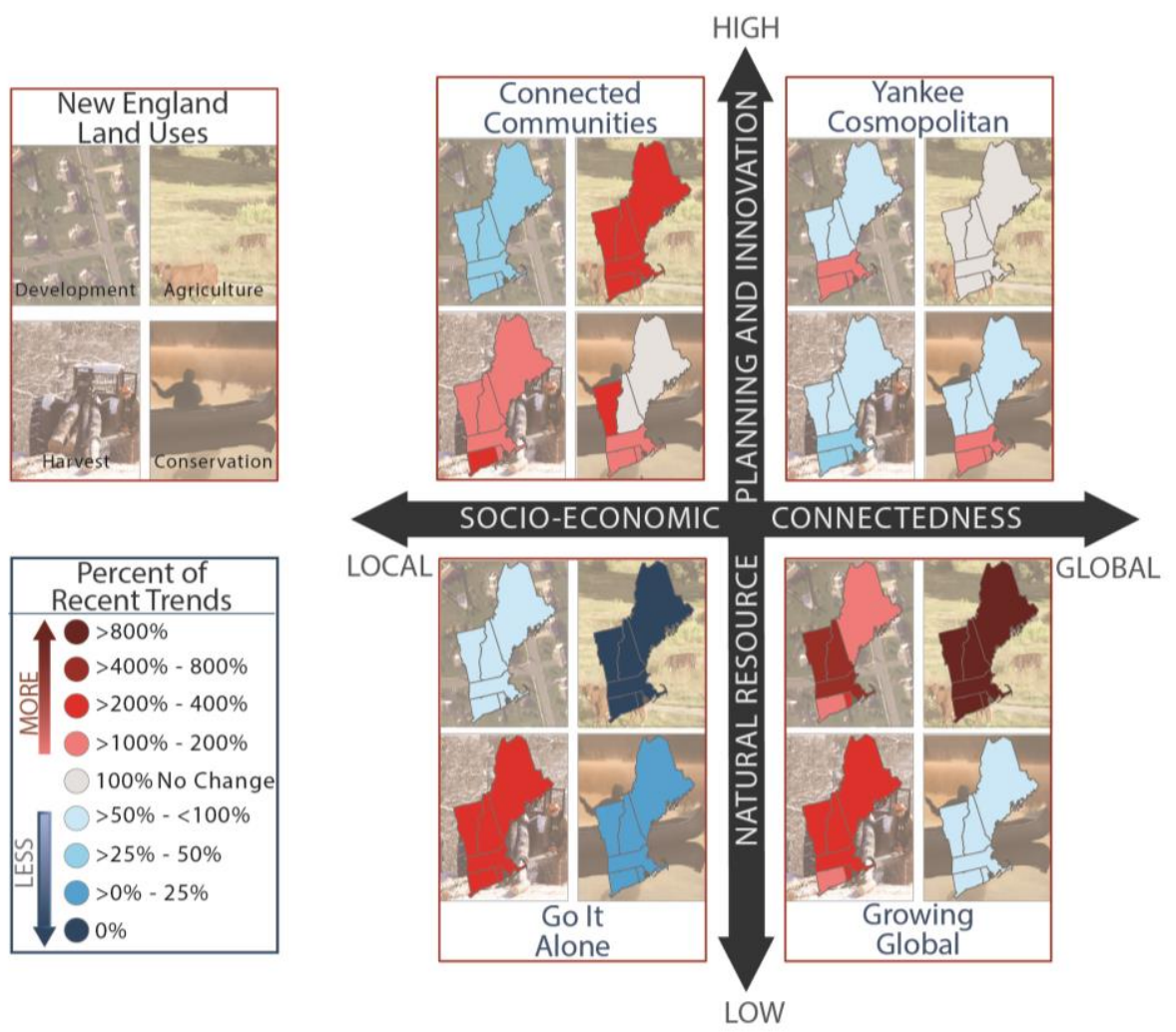

Fig. A3.2. Land cover and land use change by scenario 
Appendix 4. Full list of interactive questions presented to stakeholders during the webinar

Q1a. Do you think the regional driver "Natural resource use" effectively encompasses the related group of state drivers?
(i) Yes
(ii) No
(iii) Somewhat

Q1b. If not, how would you modify the driver?

Q2a. Do you think the regional driver "Socioeconomic connectedness" effectively encompasses the related group of state drivers?
(i) Yes
(ii) No
(iii) Somewhat

Q2b. If not, how would you modify the driver?

Q3a. Is the resulting matrix relevant to you and your work?
(i) Very useful
(ii) Useful

(iii) Somewhat useful

(iv) Not useful

Q3b. If not, what would you change?

Q4. How relevant are these storylines to you and your work?
(i) Very relevant
(ii) Somewhat relevant
(iii) A little relevant
(iv) Not very relevant
(v) Not at all relevant

Q5. For each of these storylines: (i) what would you keep? and (ii) what would you change?

Q6. For each of these storylines, is there anything missed/not included that should be?

Q7. For Scenario 1: What drives the shift towards more environmentally friendly planning and policy?

(i) Innovative energy developments helped drive this shift to occur

(ii) Increasing impacts of climate change being felt helped drive this shift to occur

(iii) Other (please specify your ideas below):

Q8. For Scenario 2: What drives the shift to localism? 
(i) A preference for local community living to counter the increasingly virtual environments used for work and socializing

(ii) A shift in social and cultural values towards preferring an eco-friendly, sustainable, lowfootprint lifestyle

(iii) Other (please specify your ideas below):

Q9. For Scenario 3: What drives the increasingly weak government, and lack of planning and regulation?

(i) A series of global energy and environmental crises heighten existing problems

(ii) An (extreme) continuation of the current pathway we are on

(iii) Other (please specify your ideas below):

Q10a. For Scenario 4: What drives the lack of investment in the environment?

(i) The full consequences of climate change and environmental degradation are felt too late to prompt any real, transformative change.

(ii) Continuation of current trends

(iii) Other (please specify your ideas below):

Q11. In Scenario 1 we envision a growing \& urbanizing population with increasing rates of "smart" development. This means that:

(i) Rates of development increase primarily around major cities in southern New England

(ii) Rates of development will increase around major and minor cities throughout New England

(iii) Development rates increase everywhere in clusters of new development, but not necessarily tied to traditional urban areas

Q12. Scenario 2: "Coordinated government is able to rise to the challenge of climate change, steering development away from the coast" Does this mean...

(i) People are incentivized to move a few feet higher in elevation

(ii) People are incentivized to move a mile or so inland

(iii) People are incentivized to move many miles inland

Q13. Scenario 2 calls for an increase in "local agriculture". How local is local?

(i) Local means more farms throughout New England, including rural areas and around populations

(ii) Local means more farms in traditional rural areas

(iii) Local means more farms around population centers

Q14. Scenario 3 envisions an increase in harvesting rates and an increase in "bad forestry".. Should the "bad forestry" rates be increased:

(i) Equally among all landowner groups

(ii) In private lands only

(iii) In industrial owned lands only

(iv) In public lands only

(v) Other (please specify your ideas below): 
Q15. Scenario 4 envisions "Low levels of government planning, and policy/regulation". What about building on wetlands?

(i) Development remains restricted on wetlands

(ii) Development will be allowed on wetlands

(iii) Development will be allowed on wetlands near large populations

Q16a. Name Scenario 1:

(i) New Yankee Urbanism

(ii) Global Village

(iii) Smart Growth at Last

(iv) Yankee Cosmopolitan

(v) Techno Fix

Q16b. If you would like, make your own suggestion(s) below:

Q17a. Name Scenario 2:

(i) Green Woodland

(ii) Small is Beautiful

(iii) Connecting, Protecting, Thriving

(iv) Small Town Americana

(v) Farm, Forest, Community

Q17b. If you would like, make your own suggestion(s) below:

Q18a. Name Scenario 3:

(i) Bootstrap World

(ii) Urban Archipelago

(iii) My Way is the Private Way

(iv) Post it if You Can

(v) Darkness on the Edge of Town

Q18b. If you would like, make your own suggestion(s) below:

Q19a. Name Scenario 4:

(i) Lots More of the Same

(ii) Wild West

(iii) Going, Going, Gone

(iv) Darkness on the Edge of Town

(v) Shining City on the Hill

Q19b. If you would like, make your own suggestion below: 